Universidade de São Paulo

Faculdade de Saúde Pública

\title{
Análise do DNA BARCODE em mosquitos (Diptera: Culicidae) neotropicais em parques da cidade de São Paulo e correlação com a paisagem
}

Laura de Freitas Souza Sayão

Tese apresentada para avaliação escrita no Programa de PósGraduação em Saúde Pública, para a obtenção do título de Doutora em Ciências

Área de concentração: Saúde Pública

Orientador: Prof. Dr. Mauro Toledo Marrelli

Coorientador: Prof. Dr. Adriano Pinter Dos Santos 
Análise do DNA BARCODE em mosquitos (Diptera: Culicidae) neotropicais em parques da cidade de São Paulo e correlação com a paisagem

\section{Laura de Freitas Souza Sayão}

Tese apresentada para avaliação escrita no Programa de PósGraduação em Saúde Pública, para a obtenção do título de Doutora em Ciências

Área de concentração: Saúde Pública

Orientador: Prof. Dr. Mauro Toledo Marrelli

Coorientador: Prof. Dr. Adriano Pinter dos Santos

Versão Revisada

São Paulo

2019 


\section{Dedicatória}

Dedico este trabalho:

Aos meus pais, que me deram a maravilhosa oportunidade destavida...

À minha mãe Maria do Rocío, zelosa e guerreira. O nosso amor existiu ontem, existe hoje e vai além da outra vida... Ao meu pai Ladislau (in memorian) amado e grande impulsionador do meu percurso...

Ao André, pelo nosso começo, pela nossa caminhada de lutas e glórias...pelo nosso futuro e pelo nosso amor! 


\section{Agradecimentos}

Agradeço primeiramente a Deus, pela vida maravilhosa que tenho e por todas as experiências nela vividas!!

À minha família pelo apoio sempre, diante da minha persistência e pelos momentos maravilhosos juntos!! André, mãe e pai (in memorian)

À vozinha Laura César (in memorian) pelas risadas, estímulos e palavras de carinho, e ao tio e padrinho Cícero Cunha (in memorian) pelo seu imenso coração...saudades de vocês!!

À minha tia Aguinalda Cunha (in memorian) e ao meu primo Diego Cunha, pelos nossos lindos momentos juntos, com a mãe e o André nos eventos e feiras de inverno e na Praia do Cassino no verão!

Ao meu orientador Dr. Mauro Toledo Marrelli, pela grande oportunidade, pela paciência, principalmente por causa do meu trabalho formal, e por acreditar no meu potencial...não tenho palavras....!

Ao meu coorientador Dr. Adriano Pinter dos Santos, pela imensa força, pela amizade e pelo estímulo;

Aos amigos doutores Paulo Roberto Urbinatti, Délsio Natal e Alexandre La Luna, pela amizade e pelas boas conversas;

Ao professor doutor Carlos James Scaini, pelas aulas maravilhosas e saudosas da graduação, e por aceitar fazer parte da minha banca;

À professora Dra. Vera Signorini, pelas aulas maravilhosas da graduação e pelas palavras de incentivo que eu nunca mais vou esquecer...

Ao DEPAVE, ao CCZ e ao pessoal de campo que fez as coletas dos mosquitos;

Ao técnico Aristides Fernandes e a bióloga Dra. Márcia Bicudo, pelas identificações morfológicas dos mosquitos;

À FURG, por plantar a semente...

À USP, por adubar a planta...

À Faculdade de Saúde Pública, por todos os momentos inesquecíveis;

Ao Instituto de Medicina Tropical pelos sequenciamentos; 
À CAPES pela bolsa concedida. Código de Financiamento 001

Ao meu Rio Grande do Sul, berço amado...

À cidade de São Paulo, gigante que me acolheu com carinho...

Às minhas amigas enfermeiras Dra. Leila, Dra. Nádia, Dra. leda, minha chefe;

À querida amiga Elisabete Estevam Alves, bibliotecária da Unianchieta, profissional competente e grande amiga de todas as horas;

À querida amiga Adriana Rafael, bibliotecária do Senac Tiradentes e agora pedagoga também;

À querida amiga Dra. Marisa, grande professora de Matemática;

À UNIANCHIETA em Jundiaí, por me proporcionar a experiência da docência, atividade fundamental na saúde pública;

A todos os colegas de laboratório e aos de outros grupos de pesquisa;

A todos os meus alunos por me ensinarem a arte das relações humanas a cada dia;

A todos os professores e pesquisadores que conheci ao longo da minha vida...muito obrigada!! 


\section{Epígrafe}

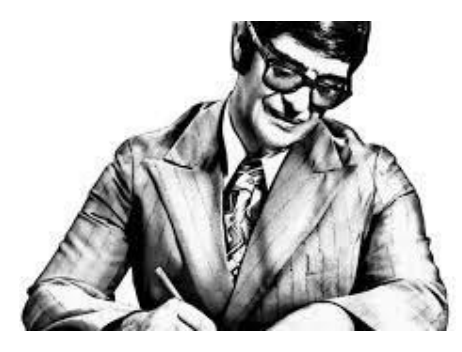

"Embora ninguém possa voltar atrás e fazer um novo começo, qualquer um pode começar agora e fazer um novo fim".

CHICO XAVIER 


\section{RESUMO}

\section{SAYÃO, L. F. S. Análise do DNA BARCODE em mosquitos (Diptera: Culicidae) neotropicais em parques da cidade de São Paulo e correlação com a paisagem}

Mosquitos são insetos dípteros, pertencentes à Família Culicidae. São encontrados em quase todas as regiões do mundo, com exceção daquelas permanentemente congeladas. A família Culicidae apresenta duas subfamílias, Anophelinae e Culicinae as quais existem principalmente na região Neotropical (América do Sul e Central). Muitas espécies de Culicidae são vetores de diversos patógenos: vírus (arbovírus), filárias (nematoides) e protozoários.

Neste projeto foram estudados espécimes adultos de vários gêneros de mosquitos oriundos dos parques da cidade de São Paulo, escolhidos por região (parques Anhanguera, Ibirapuera, Santo Dias e Shangrilá). Foi selecionado o gene mitocondrial citocromo $\mathrm{C}$ oxidase subunidade $\mathrm{I}(\mathrm{COI})$ que tem sido extensivamente usado para estudos populacionais e para resolver relacionamentos entre grupos fechados de espécies de insetos. $O$ marcador mostrou-se adequado para as análises. As sequências foram comparadas através de métodos de análises evolutivas (UPGMA e Neighbor-joining).

A utilização de outros marcadores como por exemplo microssatélites, para a continuidade dos estudos e futuras confirmações das espécies Cq. venezuelensis, Ma. titillans, Cx. declarator, Wy. sp., Cx. (Mel) ribeirensis e (Mel) Ma. wilsoni é uma necessidade, assim como os registros das respectivas sequências no banco de genes produzidas nesta pesquisa.

O parque Anhanguera, mais distante dos aglomerados humanos, proporciona a circulação de parasitas de infecções silvestres; o parque Ibirapuera, no centro da malha urbana, favorece as espécies mais antropofílicas e sinantrópicas.

Palavras-chave: Culicidae, mosquitos, $\mathrm{COI}$, paisagem, molecular. 


\section{ABSTRACT}

\section{SAYÃO, L. F. S. Analysis of BARCODE DNA in neotropical mosquitoes (Diptera: Culicidae) in parks of the city of São Paulo and correlation with the landscape}

Mosquitoes are dipterous insects, belonging to the Culicidae family. Are found in almost all regions of the world, with the exception of those permanently frozen. The Culicidae family features two subfamily Anofelinea and Culicinae to which there are mainly in the Neotropical region (South and Central America). These agents cause illnesses and injuries in men and animals, receiving special attention for hematophagic habit.

On this project we studied adult specimens of several mosquito genera from the city of São Paulo, chosen by region (parks Anhanguera, Ibirapuera, Santo Dias and Shangrilá). We selected the mitochondrial cytochrome C oxidase I (COI) gene that has been extensively used for population studies and to resolve relationships between closed groups of insect species. The marker proved to be adequate for the analyzes. The sequences were compared by methods of evolutionary analysis (UPGMA and Neighbor-joining).

The use of other markers such as microsatellites for the continuity of studies and future confirmations of the species Cq. venezuelensis, Ma. titillans, Cx. declarator, Wy. sp., Cx. (Mel) ribeirensis and Ma. wilsoni and a need, as well as the records of the respective sequences in the gene bank produced in this research.

The Anhanguera park furthest from human settlements, provides the circulation of wild-type parasites; the lbirapuera park at the centre of the urban network, favors the more anthropogenic and synanthropic species.

Key words: Culicidae, mosquitoes, COI, landscape, molecular 


\section{SUMÁRIO}

\section{1- INTRODUÇÃO}

1.1. FAMÍLIA CULICIDAE ............................................................11

1.2. MARCADORES MOLECULARES E SUA IMPORTÂNCIA PARA A ENTOMOLOGIA

1.3. GENOMA MITOCONDRIAL E O GENE CITOCROMO C OXIDASE I (COI) $\quad 16$

1.4. ANÁLISES EVOLUTIVAS

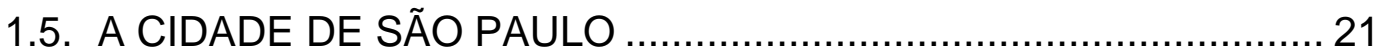

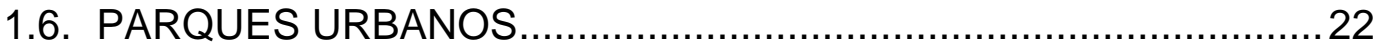

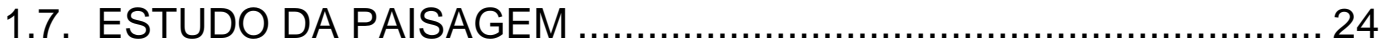

2- OBJETIVOS

2.1. GERAL

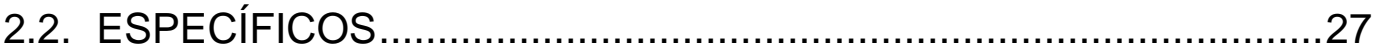

3- MATERIAL E MÉTODOS

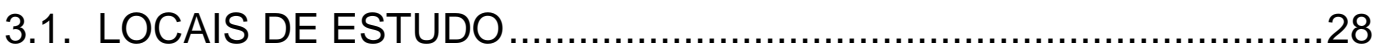

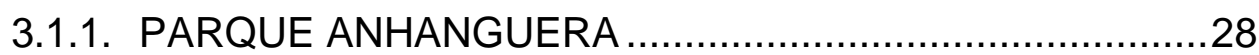

3.1.2. PARQUE IBIRAPUERA ................................................. 30

3.1.3. PARQUE SANTO DIAS............................................... 32

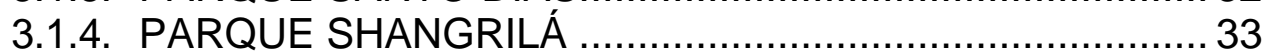

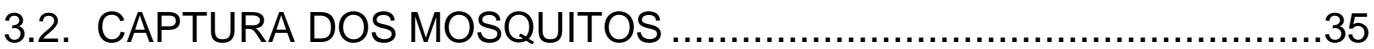

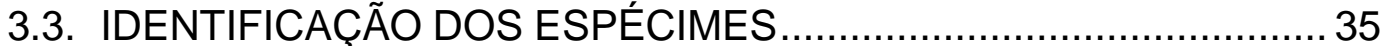

3.4. EXTRAÇÃO DO DNA GENÔMICO …......................................... 36

3.5. REAÇÃO EM CADEIA PELA POLIMERASE ................................ 36

3.6. ELETROFORESE EM GEL DE AGAROSE ................................ 37

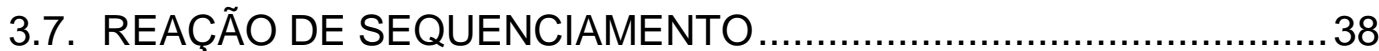

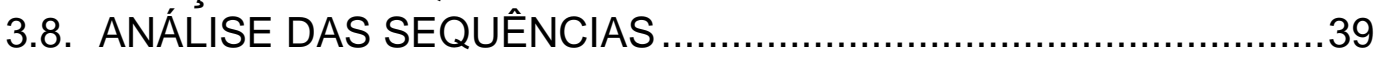

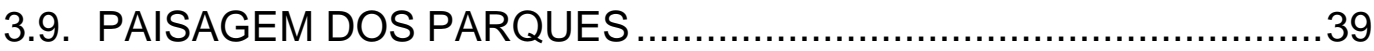

4- RESULTADOS

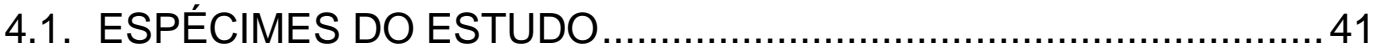

4.2. AMPLIFICAÇÃO E QUANTIFICAÇÃO DO MATERIAL ................... 42

4.3. SEQUENCIAMENTO DAS AMOSTRAS...................................... 43

4.4. CARACTERÍSTICAS DAS SEQUÊNCIAS................................ 43

4.5. PORCENTAGEM DE SIMILARIDADE ....................................... 43

4.6. ALINHAMENTOS ................................................................. 47

4.7. ÁRVORES FILOGENÉTICAS .................................................. 52

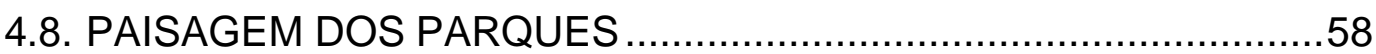

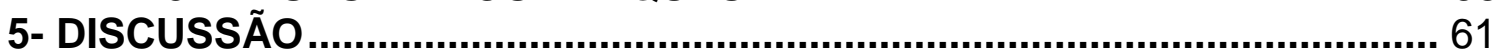

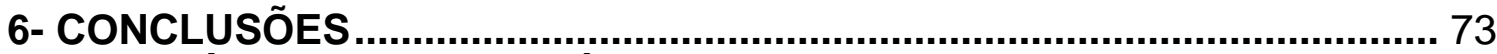

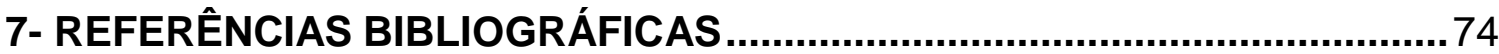

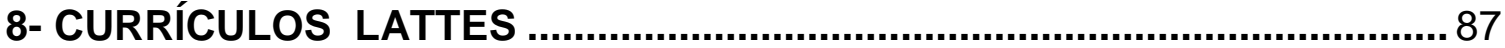




\section{LISTA DE SIGLAS E ABREVIAÇÕES}

COI - citocromo c oxidase I

CR- Control region ou região controladora

DLOOP-Displacement loop ou região controladora

DNAmit - DNA mitocondrial

EDTA- Ácido etilenodiaminotetracético

FSP - Faculdade de Saúde Pública

g- aceleração da gravidade

LB- loading buffer

LESP- Laboratório de Entomologia em Saúde Pública

ml - mililitros

mv- milivolts

PCR- Reação em cadeia pela polimerase

pb-Pares de base

qsp- quantidade suficiente para

SP- São Paulo

Taq polymerase - enzima DNA polimerase

TBE- Tris borato EDTA

$\boldsymbol{\mu l}$ - microlitros

$\mu \mathrm{M}$ - micromolar

UBS- Unidade Básica de Saúde

UPGMA- Unweighted Pair Group Method with Arithmetic Mean

USP- Universidade de São Paulo

V- Volt 
Figura 1- Regiões zoogeográficas ou ecozonas terrestres............................. 11

Figura 2- Mosquitos Culicidae adultos...................................................... 12

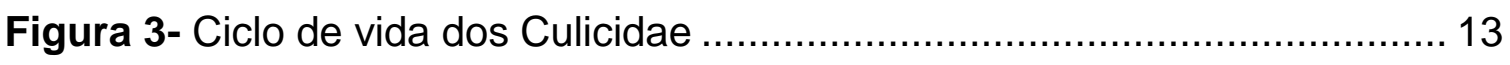

Figura 4- Visão geral do interior da célula eucariótica, mitocôndria e DNAmit...17

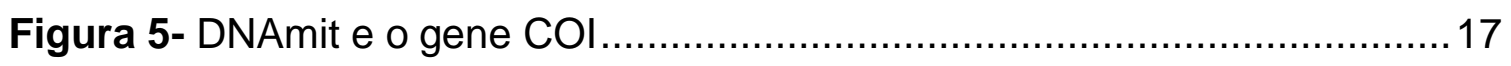

Figura 6- Mapa da cidade de São Paulo com a localização dos parques .........24

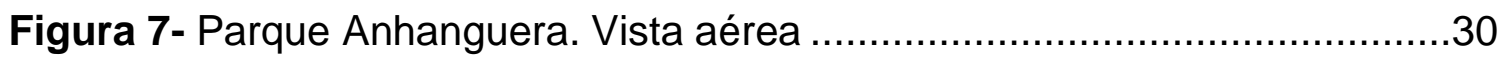

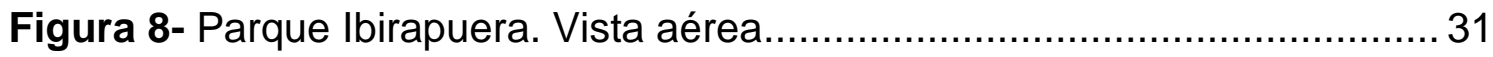

Figura 9- Parque Santo Dias. Vista aérea ......................................................33

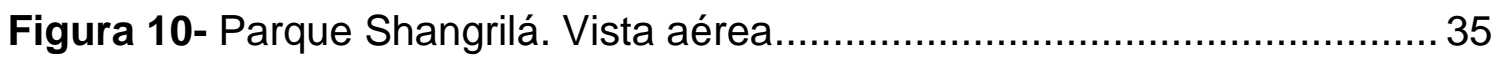

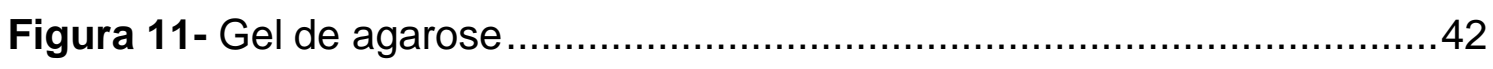

Figura 12- Alinhamento de Ae. albopictus o parque Ibirapuera ....................... 48

Figura 13- Alinhamento de Wy. sp. do parque Santo Dias ................................49

Figura 14- Alinhamento de Ma. wilsoni do parque Shangrilá........................... 50

Figura 15- Resultados do GenBank $®$ de Ma. titillans do parque Ibirapuera ..... 50

Figura 16- Resultados do GenBank $®$ de $C x$. declarator do parque lbirapuera..51 Figura 17- Resultados do GenBank® de Cq. venezuelensis do parque

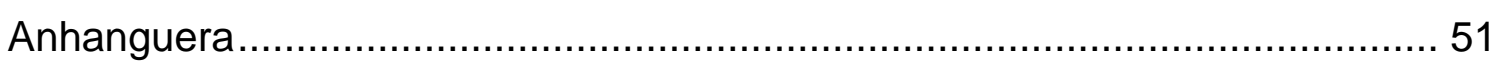

Figura 18- Árvore UPGMA do parque Anhanguera .......................................52

Figura 19- Árvore Neighbor-joining do parque Anhanguera ..............................52

Figura 20- Árvore UPGMA do parque Ibirapuera .......................................... 53

Figura 21- Árvore Neighbor-joining do parque Ibirapuera................................ 53

Figura 22- Árvore UPGMA do parque Santo Dias ........................................54

Figura 23- Árvore Neighbor-joining do parque Santo Dias ..............................54

Figura 24- Árvore UPGMA do parque Shangrilá............................................. 55

Figura 25- Árvore Neighbor-joining do parque Shangrilá................................ 55

Figura 26- Árvore UPGMA com todos os 28 espécimes ..................................56

Figura 27- Árvore Neighbor-joining com todos os 28 espécimes......................57

Figura 28- Área de abrangência e entorno de cada parque .............................59

Figura 29- Distâncias euclidianas entre os parques ........................................60 
Tabela 1- Genes comumente encontrados no DNA mitocondrial de animais ... 18 Tabela 2- Descrição das sequências dos primers utilizados para a

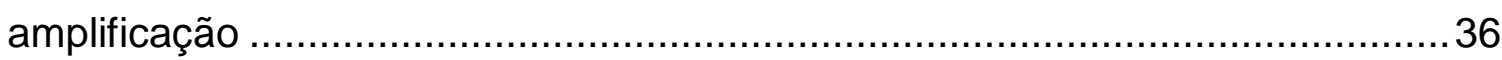

Tabela 3- Descrição das condições da reação de PCR .................................... 37

Tabela 4- Descrição dos reagentes da reação de sequenciamento ....................38

Tabela 5- Espécimes dos mosquitos coletados por parque .............................. 41

Tabela 6- Porcentagem de similaridade das sequências do parque

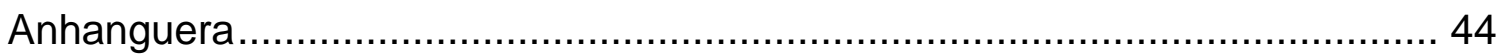

Tabela 7- Porcentagem de similaridade das sequências do parque Ibirapuera

Tabela 8- Porcentagem de similaridade das sequências do parque Santo Dias

Tabela 9- Porcentagem de similaridade das sequências do parque Shangrilá

Tabela 10- Descrição das áreas de cobertura vegetal de cada parque distâncias euclidianas entre os parques .58 


\section{1- INTRODUÇÃO}

\subsection{FAMÍLIA CULICIDAE}

A família Culicidae da ordem Diptera, subordem Nematocera é de suma importância para os estudos epidemiológicos, entomológicos para o controle de agentes causadores e doenças. São um grupo grande e abundante de insetos de distribuição cosmopolita, principalmente na região Neotropical, (América do Sul e Central ), (FORATTINI, 2002) Figura 1, e muito além do círculo Ártico (HARBACH, 2013). Os mosquitos são mais diversos em ambientes de florestas tropicais e são conhecidos popularmente também como pernilongos, muriçocas, ou carapanãs. Os Culicidae contam com 3.565 espécies, classificadas em 2 subfamílias e 113 gêneros. A subfamília Anophelinae possui três gêneros e Culicinae 110 gêneros segregados em 11 tribos (HARBACH, 2013).

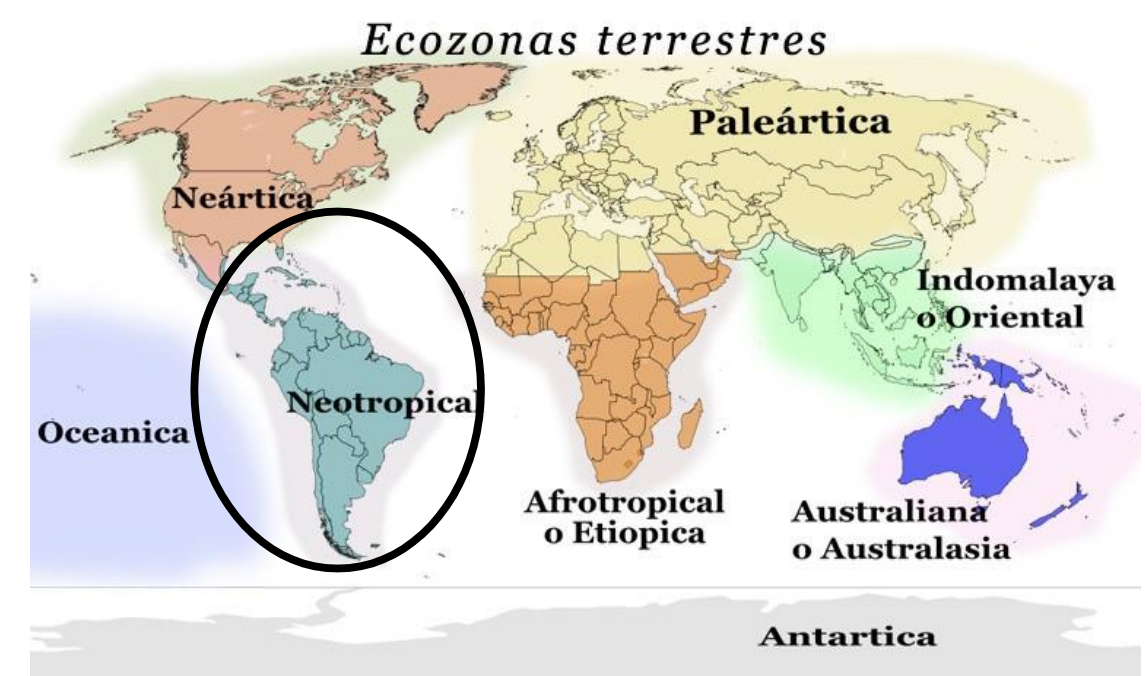

Figura 1- Mapa mundi com a distribuição das regiões zoogeográficas ou ecozonas terrestres. Em destaque no círculo, a região neotropical (em azul claro). Fonte:http://www.megatimes.com.br/2014/05/zoogeografia-eas-regioes-faunisticas.html 
Os adultos são insetos delicados, alados, possuem pernas e antenas longas e, na sua grande maioria são hematófagos. As fêmeas de diversas espécies se alimentam do sangue de animais, mas outras podem produzir ovos sem uma refeição de sangue (Figura 2). Os vertebrados de sangue quente são uma fonte comum de sangue para a maioria das espécies, mas muitas também parasitam animais de sangue frio, como sapos, tartarugas, cobras, rãs e outros insetos, incluindo cigarras ninfas, mantídeos e larvas de lepidópteros (HARBACH, 2013). O corpo é dividido em cabeça, tórax e abdome e, são reconhecidos pela sua longa tromba e pela presença de escamas ao longo do corpo. Apresentam metamorfose completa, passando pelos estágios de ovo, larva (4 estádios larvais) e pupa (Figura 3), sendo que todas as fases imaturas apresentam o seu desenvolvimento na água e adulto (CONSOLI \& LOURENÇODE-OLIVEIRA, 1994). Em relação ao tempo de voo, algumas espécies são ativas à noite ou no período crepuscular, enquanto outras preferem o dia (HARBACH, 2013).

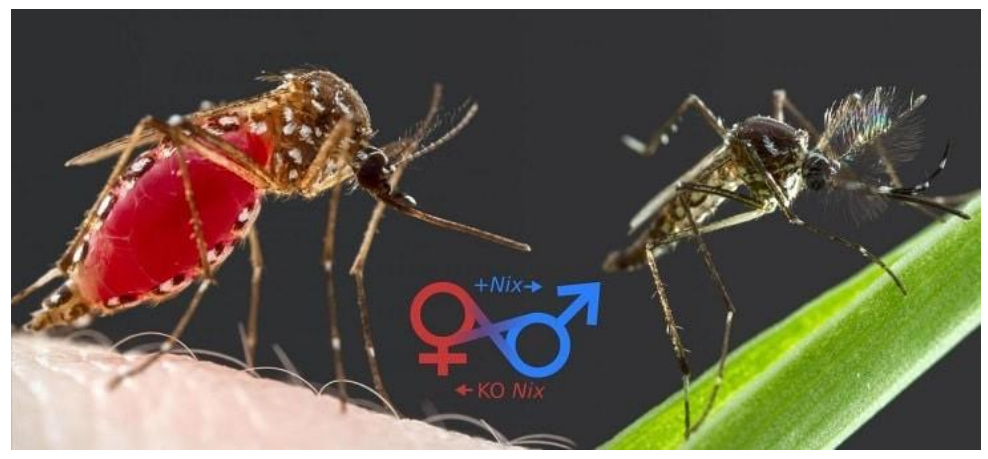

Figura 2- Mosquitos Cullicidae adultos. Fêmea à esquerda, com o abdome ingurgitado. Macho à direita. Fonte: http://topbiologia.com 


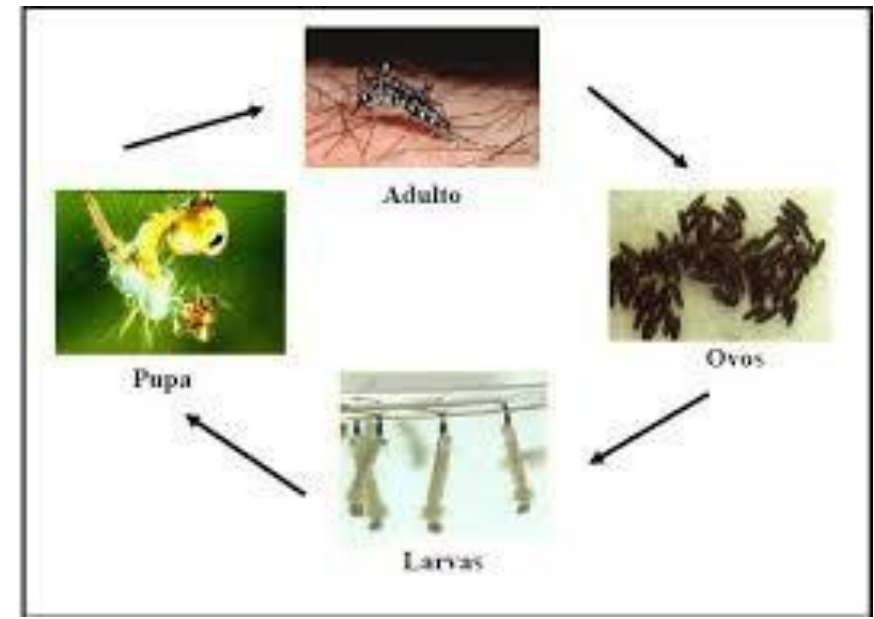

Figura 3- Ciclo de vida dos Culicidae, na sequência: ovo, larva, pupa e adulto. Fonte: CPqAM/Fiocruz

Muitas espécies da família Culicidae são vetores de agentes patogênicos como vírus (arbovírus), filárias (nematoides) e protozoários (REY, 2008; SILVA, 2009). Menos do que 150 espécies compreendidas nos gêneros Anopheles, Aedes e Culex são indiretamente causadores de maior morbidade e mortalidade que qualquer outro grupo de organismos (HARBACH, 2007).

No Brasil, destacam-se as espécies Culex quinquefasciatus, Aedes aegypti e Anopheles sp. além de outras espécies dos gêneros Culex (NATAL et al, 2004). A espécie Culex quinquefasciatus é o transmissor primário da Wuchereria bancrofti (CONSOLI \& LOURENÇO-DE-OLIVEIRA, 1994) causador da filariose linfática. Está muito adaptado ao convívio humano, ocasionando extremo incômodo, como ao que ocorre aos moradores de uma área próxima às margens do Rio Pinheiros na cidade de São Paulo (MORAES, MARRELLI \& NATAL, 2006). O Aedes aegypti é o transmissor dos vírus da dengue (DENV), chikungunya (CHIKV) e zikavírus que são considerados importantes desafios da saúde pública (HONÓRIO et al, 2015). 


\subsection{MARCADORES MOLECULARES E SUA IMPORTÂNCIA PARA A ENTOMOLOGIA}

Atualmente, são utilizadas técnicas de Biologia molecular nas diferentes áreas da Entomologia. Esta estratégia tem sido possível devido aos inúmeros estudos e ao avanço nas pesquisas do genoma de insetos.

$\mathrm{Na}$ Entomologia forense, que consiste na ciência aplicada ao estudo dos insetos e outros artrópodes em procedimentos legais por exemplo, é possível o isolamento, a amplificação e a caracterização do material genético humano encontrado no trato digestório de artrópodes necrófagos e hematófagos sendo fundamental para a estimativa do intervalo pós-morte (SANDOVAL, 2011). A grande maioria dos insetos necrófagos adultos pode ser identificada através da taxonomia morfológica, o que não ocorre com os imaturos. Uma das vantagens do uso de marcadores moleculares é a recuperação da identidade do inseto, independentemente do estágio de desenvolvimento do organismo e não são influenciados pelas condições ambientais (HAYMER \& MCINNIS, 1994). A relevância da estratégia é também demonstrar a origem geográfica do espécime em questão, acusando o local da ocorrência. Esta aplicação mostra-se útil na identificação de cadáveres em estado de decomposição pois, a atividade desses insetos adultos e imaturos acelera a putrefação e a desintegração da carcaça (OLIVEIRA-COSTA, 2008).

O estudo dos insetos na Entomologia forense responde a outras questões como: a causa da morte (OLIVA, 2001), a investigação do uso de substâncias tóxicas e narcóticos pela vítima (O'BRIEN \& TURNER, 2004), situação de maus tratos a seres humanos (BENECKE et al, 2004) e animais (ANDERSON \& HUITSON, 2004).

Para a Entomologia agrícola, ciência que estuda os insetos que infestam as plantações que o homem cultiva e as plantas silvestres de importância econômica, o estudo de marcadores facilita o esclarecimento de dúvidas a respeito das relações filogenéticas entre grupos de insetos-praga proporcionando informações para a implantação de um controle genético desses grupos. As espécies de mosca-branca associadas às desordens ou anomalias fisiológicas em aboboreira e tomateiro, por exemplo, são identificadas pela 
taxonomia convencional ou clássica. Esta tem se mostrado ineficaz para esse inseto, uma vez que dentro do complexo Bemisia tabaci (Genn) (Hemiptera: Aleyrodidae) há 24 espécies morfologicamente indistinguíveis (DE BARRO \& AHMED, 2011).

$\mathrm{Na}$ Entomologia médica e veterinária, são crescentes as inúmeras pesquisas relacionadas ao controle de pragas no que diz respeito a estudos da distribuição geográfica, comportamento, biologia reprodutiva etc, para a compreensão de padrões evolutivos através do uso da Biologia Molecular. Além disso, permite a associação a estudos de identificação e nomenclatura de espécies através das técnicas taxonômicas tradicionais. Do ponto de vista epidemiológico, essa colaboração é importante para programar medidas mais efetivas de controle de vetores (SILVA, 2009).

Em entomologia, nas pesquisas sobre filogenia e sistemática de insetos os pesquisadores utilizam, de forma não coordenada marcadores moleculares diversos em várias situações. Isso gera algumas dificuldades quando da análise de grupos taxonômicos e suas relações (CATERINO et al, 2000). A escolha do marcador molecular adequado proporciona uma ferramenta importante nas pesquisas e, depende de vários fatores como por exemplo, da abordagem biológica, da quantidade de DNA, dos conhecimentos técnicos do investigador e do equipamento disponível no laboratório. Além disso, uma série de outros fatores relacionados com o organismo alvo e a sua complexidade do genoma também desempenham um papel importante na seleção do marcador ou tecnologia a ser utilizada (TURCHETTO-ZOLET, 2013). Da mesma forma, a escolha do marcador deve ser adequada para atender os objetivos do estudo em questão. 


\subsection{GENOMA MITOCONDRIAL E O GENE CITOCROMO C OXIDASE I (COI)}

A mitocôndria é uma organela alongada que se localiza no citoplasma. É especializada na disponibilização de energia para a célula e possui cromossomos próprios de herança materna (Figura 4). Acredita-se que são descendentes de células bacterianas primitivas, que foram fagocitadas simbioticamente por ancestrais eucarióticos e que evoluíram para organelas dentro das células. É onde ocorre a fosforilação oxidativa, reação essencial para a produção de ATP, assim como uma variedade de outras funções bioquímicas (BOORE, 1999)

O DNA mitocondrial (mtDNA ou DNAmit) dos animais é de organização simples, sendo constituído, na grande maioria dos casos, por até 10 cópias de uma única fita circular com 37 genes (Figura 5). Dois deles codificam RNAs ribossômicos, 22 codificam RNAs transportadores e 13 codificam polipeptídeos (BOORE, 1999; FARAH, 2000;) tabela 1. Não possui DNA repetitivo, transposons, introns ou pseudogenes (WILSON et al, 1985). São encontradas poucas inserções, porém, quando presentes, constituem regiões intergênicas não-codificadoras.

A maior sequência não-codificante, com cerca de 1000 pb, é a região controladora (Control Region $\mathrm{CR}$ ), que tem função regulatória na dinâmica da molécula controlando a replicação e a transcrição do genoma da mitocôndria (SILVA, 2009). Esta região é referida nos vertebrados como D-loop (Displacement- loop), é muito variável e, portanto importante na identificação dos indivíduos (FARAH, 2000). 

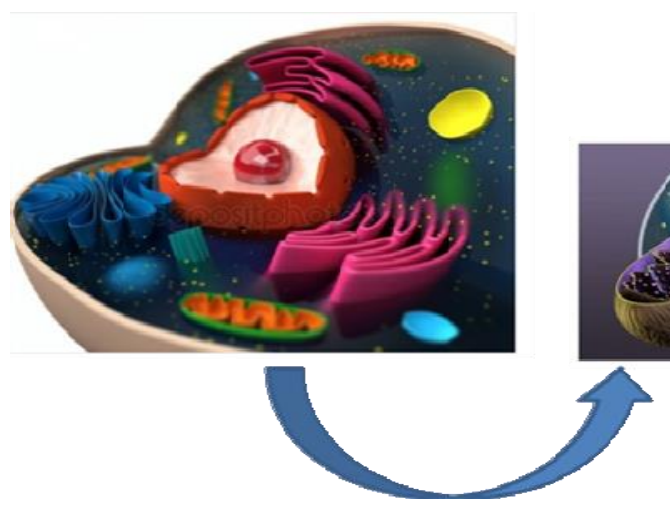

A
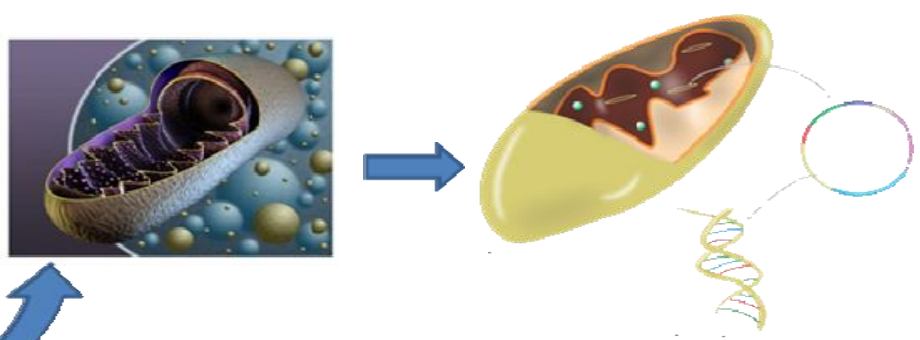

B

C

Figura 4- A: visão geral do interior da célula eucariótica, evidenciando as principais organelas e em destaque (seta), a mitocôndria. B: mitocôndria em corte horizontal. Observa-se no seu interior as cristas ou dobras mitocondriais. C: mitocôndria estilizada em corte horizontal e a localização das moléculas do DNAmit. Fonte: https://medicalia.ning.com e http://www.ufac.br/ccbn/genetica/index.html

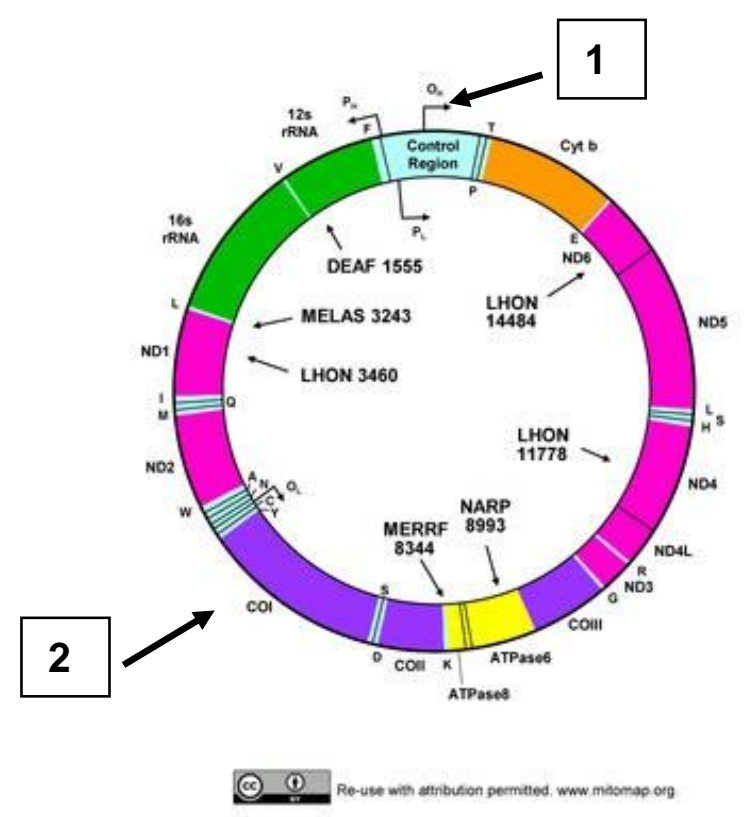

Figura 5- DNAmit (DNA circular com os 37 genes). 1 : sequência não-codificante, com cerca de 1000 pb, é a região controladora (Control Region CR), referida nos vertebrados como D-loop (Displacement- loop). 2: DNA barcode, é a subunidade I (COI) do gene citocromo $\mathrm{c}$ oxidase

Fonte: https://ghr.nlm.nih.gov 
Tabela 1- Genes comumente encontrados no DNA mitocondrial de animais, de acordo com a revisão de Boore, 1999

\begin{tabular}{|c|c|c|}
\hline Codificador de proteínas & $\begin{array}{l}\text { Designação do DNAmit } \\
\text { para os animais }\end{array}$ & Sinônimo \\
\hline $\begin{array}{l}\text { Citocromo c oxidase } \\
\text { subunidades I, II e III }\end{array}$ & COI, COll, COllI & $\begin{array}{l}\operatorname{cox} 1, \operatorname{cox} 2 \\
\operatorname{cox} 3\end{array}$ \\
\hline Citocromo b apoenzima & Cytb & $C O B$ \\
\hline $\begin{array}{l}\text { Nicotinamina adenina } \\
\text { dinucleotídeo (NAD) } \\
\text { desidrogenase subunidades } \\
1-6,4 \mathrm{~L}\end{array}$ & ND1-6, ND4L & nad1-6, nad4L \\
\hline $\begin{array}{l}\text { Trifosfato de adenosina } \\
\text { (ATP) sintetase } \\
\text { subunidades } 6,8\end{array}$ & ATP6, ATP8 & $\begin{array}{l}\text { atp6, atp8 ou } \\
\text { A6, } \\
\text { A8 }\end{array}$ \\
\hline $\begin{array}{l}\text { Subunidade maior do RNA } \\
\text { ribossomal }\end{array}$ & $16 S$ & LrRNA, $m l$ \\
\hline $\begin{array}{l}\text { Subunidade menor do RNA } \\
\text { ribossomal }\end{array}$ & $12 S$ & SrRNA, MS \\
\hline $\begin{array}{l}18 \text { RNAs transportadores } \\
\text { cada um especificando um } \\
\text { aminoácido }\end{array}$ & $\begin{array}{l}\text { Com a primeira letra do aminoácido } \\
\text { correspondente }\end{array}$ & $\operatorname{Trn} X$ \\
\hline $\begin{array}{l}\text { Dois RNAs } \\
\text { transportadores } \\
\text { específicos para leucina }\end{array}$ & $\begin{array}{l}\text { Diferenciado pelo código } \\
\text { Reconhecido } L(C U M) \text { ou } L(U U R)\end{array}$ & $\begin{array}{l}\text { Diferenciado } \\
\text { pelo código }\end{array}$ \\
\hline $\begin{array}{l}\text { Dois RNAs transportadores } \\
\text { específicos para serina }\end{array}$ & $\begin{array}{l}\text { Diferenciado pelo código } \\
\text { Reconhecido } S(A G M) \text { ou } S(U C N)\end{array}$ & $\begin{array}{l}\text { Diferenciado } \\
\text { pelo código }\end{array}$ \\
\hline
\end{tabular}

Em 2003, pesquisadores canadenses da Universidade de Guelp (Ontário), objetivando padronizar um marcador que fosse utilizado na identificação de espécies animais, sugeriram a criação de um código de barras do DNA, pois as sequências desse gene funcionariam como um código de barras semelhante ao que existe no mercado para comércio de produtos (HEBERT et al, 2003). 
Esse marcador, que foi denominado DNA barcode, é a subunidade I (COI) do gene citocromo c oxidase (Figura 5). Esse gene codifica uma proteína pequena e muito conservada, situada na face externa da membrana interna da mitocôndria (proteína heme). É periférica e seu tamanho e mobilidade permitemIhe cumprir sua função na cadeia de transporte de elétrons para a molécula de oxigênio (TORRES,1999) e no mecanismo de morte (apoptose) celular (ZHAO et al, 2008). A região do gene que está sendo usado para quase todos os grupos de animais tem cerca de 648 pb e está se mostrando altamente eficaz na identificação de pássaros, borboletas, peixes, moscas e outros grupos de animais (HEBERT, 2003). Devido a inúmeras vantagens estruturais e às grandes diferenças que apresenta entre as espécies animais relacionadas à sua alta taxa de mutação, torna-se o método de escolha de estudos de identificação de espécies e de evolução.

Utiliza-se o DNAmit quando a amostra em questão é muito pequena ou apresenta-se muito danificada, já que cada célula possui inúmeras mitocôndrias, mesmo amostras obtidas em péssimas condições, na maioria das vezes é possível ter o DNA amplificado por PCR (Reação em cadeia pela polimerase). Podem ser obtidas sequências parciais ou totais do DNA barcode para análise. Uma base de dados integrada chamada BOLD-Systems (Barcodes of Life Data Systems) foi criada para armazenar e disponibilizar os códigos de barras do DNA, e outras informações como pontos de coleta de amostras, outros genes estudados do táxon em questão, dados morfológicos dos espécimes analisados pelos taxonomistas.

Em Entomologia, nos estudos sobre filogenia e sistemática de insetos os pesquisadores utilizam, de forma não coordenada marcadores moleculares diversos, gerando dificuldades quando na análise das relações entre diferentes grupos taxonômicos (CATERINO et al, 2000). Entretanto, na maioria dos estudos recentes sobre mosquitos de importância em Saúde Pública, as regiões do citocromo c oxidase tem sido extensivamente usadas para estudos populacionais e para resolver relacionamentos entre grupos fechados de espécies de insetos (LUNT et al, 1996) e mosquitos anofelinos (KRZYWINSKI E BESANSKY, 2003), assim como filogenia e filogeografia de diversos grupos da família Culicidae (SALLUM et al, 2002, SCARPASSA \& CONN, 2006, SAENG 
et al, 2007, PATSOULA et al, 2007, SCARPASSA et al, 2008, SILVA et al, 2011). Variações neste fragmento tem sido exploradas como DNA barcodes para a identificação de mosquitos Culicidae, incluindo An. fluviatilis (KUMAR et al, 2007). De acordo com o HEBERT et al, (2003), a sequência contida no gene coxl do DNAmit permite a identificação de espécies e até a descoberta de novas espécies.

\subsection{ANÁLISES EVOLUTIVAS}

Os métodos utilizados para inferência filogenética (análise da história do genoma) utilizando sequências são os seguintes: métodos baseados em distâncias, máxima parcimônia, máxima verossimilhança e Bayesiana. Os métodos baseados em distâncias entre sequências são os mais velozes computacionalmente, o que facilita o seu uso na análise de grandes quantidades de OTUs- unidades taxonômicas operacionais ou táxons (TAMURA \& NEI, 1993).

Métodos baseados em parcimônia (YANG \& KUMAR, 1996) procuram uma árvore que minimize o número de passos necessários para explicar os padrões observados nos dados (SWOFFORD, 1998). Após os sítios informativos serem selecionados, a árvore que requer o menor comprimento é selecionada como a mais parcimoniosa.

Na máxima verossimilhança é necessário estabelecer um algoritmo de busca para obter a melhor tipologia. Alguns autores preferem este método, pois estudos recentes mostraram ser mais acurado para inferir a árvore que outros existentes (LIÓ \& GOLDMAN, 1998; GUIDON \& CASCUEL, 2003). Na análise Bayesiana as árvores também se baseiam na máxima verossimilhança, só que os valores não são otimizados como ocorre nesta. Assim os resultados são expressos em termos de probabilidade posterior, levando em conta todos os parâmetros. 


\subsection{A CIDADE DE SÃO PAULO}

A população dos municípios que compõem a grande São Paulo, alcança a cifra de 20,5 milhões de habitantes (http://www.ibge.gov.br). Por esse motivo, sofre o estresse ambiental próprio das maiores metrópoles do planeta, que inclui fatores como: pavimentação excessiva, ilhas de calor, poluição atmosférica, adensamento populacional, exclusão social, violência, entre outros. As alterações no ambiente antrópico e a queima de combustíveis fósseis, contribuem com a elevação de concentração de $\mathrm{CO} 2$ e, consequentemente, com mudanças climáticas; também as inundações, consideradas um dos maiores problemas associados com o desenvolvimento urbano, devido à deficiência no sistema de drenagem (SILVÉRIO \& URBINATTI, 2011). Esse acúmulo de água propicia a geração de milhares de criadouros para mosquitos dentro da cidade.

$\mathrm{Na}$ cidade de São Paulo há parques municipais que preservam fragmentos da vegetação original, comportam lagos, servem de abrigo para aves e mamíferos silvestres e são visitados continuamente por um intenso número de pessoas como ambientes de lazer (GUIA DOS PARQUES MUNICIPAIS DE S. PAULO SMVMA-2014). Essas "ilhas verdes" têm condições de manter populações de algumas espécies de mosquitos ou servir de refúgio para espécies exóticas como Ae. aegypti, Ae. albopictus e Cx. quinquefasciatus (MEDEIROS-SOUSA et al, 2013). Lembrando que quanto mais intensa for a proliferação do mosquito e maior a densidade populacional humana, maiores são as chances de contato.

Trabalhos pontuais, em áreas periféricas, indicam abundância relativamente elevada de mosquitos (URBINATTI et al, 2001; TAIPE-LAGOS \& NATAL, 2003; MONTES, 2005; LAPORTA et al, 2006; MORAES et al, 2006;

SILVÉRIO \& URBINATTI, 2011). Esses registros sugerem que alguns membros desse táxon subsistiram ou adaptaram-se ao processo de urbanização nessa metrópole, dispersando-se e sendo considerados vetores potenciais ou secundários de patógenos causadores de doenças.

As mudanças nas atividades desses insetos decorrentes de processos de intervenções humanas no ambiente já foram observadas para várias espécies 
então, diante do exposto, considerando que essas drásticas mudanças ambientais proporcionam uma estrutura ecológica única dentro da região metropolitana, justifica-se estudar a fauna de mosquitos associada às áreas protegidas utilizadas para lazer no interior da malha urbana da cidade, investigar aspectos ecológicos, epidemiológicos (MEDEIROS-SOUSA et al, 2013) e moleculares dessas populações.

\subsection{PARQUES URBANOS}

De acordo com a Lei 9.985, de julho de 2000, da Constituição Federal, que institui o Sistema Nacional de Unidades de Conservação da Natureza e dá outras providências, no Art. 11 está descrito que: "O Parque Nacional tem como objetivo básico a preservação de ecossistemas naturais de grande relevância ecológica e beleza cênica, possibilitando a realização de pesquisas científicas e o desenvolvimento de atividades de educação e interpretação ambiental, de recreação em contato com a natureza e de turismo ecológico". Já o inciso $4^{\circ}$ detalha que: "As unidades dessa categoria, quando criadas pelo Estado ou Município, serão denominadas, respectivamente, Parque Estadual e Parque Natural Municipal" (LEI 9.985, DE JULHO DE 2000).

Com base na legislação vigente, pode-se dizer de modo menos formal, que os parques públicos urbanos são áreas verdes destinadas a passeios, lazer, prática de esportes, educação ambiental e outras atividades das pessoas que moram nas cidades e, que procuram um momento de diversão, descanso e até de aprendizado. Existem praticamente em todos os países e todas as culturas adaptando-se de acordo com os hábitos da população. Podem ser artificiais, com áreas planejadas e replantadas pelo homem ou naturais, onde as pessoas aproveitam recantos de matas ou florestas com ou sem água corrente.

Inicialmente esses locais surgiram como jardins particulares há muito tempo, através da organização dos elementos naturais (pedras, plantas e tanques) como ornamento em pequenos espaços sem preferência de lugar, inclusive nos desertos. Como um exemplo mais aprimorado, destacam-se os jardins egípcios. Até onde conhecemos, ficou como registro histórico um notável 
grau de desenvolvimento técnico, onde se aplicam sistemas agrícolas e hidráulicos bem avançados (FARIELLO, 2004).

Os parques propriamente ditos, surgiram primeiramente na Europa em 1.789 em Munich, com a finalidade de recreação pública. Em outros lugares como Paris por exemplo, o sistema de parques criado tinha outros objetivos que não prioritariamente atender a população (MAGNOLI, 2006). Somente em Nova York (EUA), com o Central Park, observa-se um planejamento criado para beneficiar as pessoas.

O Estado de São Paulo localizado na região sudeste do Brasil, tem como capital a cidade de São Paulo (23.54ํㅡ, W6.63ํㅗ S), com uma população de 12.106.920 habitantes (IBGE, 2017), é a maior e mais populosa cidade da América Latina. Ela possui até o momento, 106 parques municipais que são considerados patrimônios e servem de locais para a conscientização e preservação da biodiversidade, através da educação para o meio ambiente.

Nessa cidade, os parques existentes se originaram próximos aos limites das áreas urbanas e, aos poucos, foram sendo incorporados à cidade como 0 Parque do Ibirapuera, que hoje está localizado na área central (MENNEH, 2000). Eles estão divididos por regiões e administrados pela Secretaria Municipal do Verde e Meio Ambiente (PREFEITURA DE SÃO PAULO - VERDE E MEIO AMBIENTE, 2017).

Os parques são importantes, principalmente para uma cidade imensa e sem praias como São Paulo. Essa importância se dá pelo fato de, além da amenização do clima, o aprimoramento da vida cultural, a valorização do entorno e o aumento dos investimentos imobiliários e comerciais.

No estudo foram selecionados quatro parques de São Paulo, devido a sua localização geográfica estratégica, abrangendo quatro áreas que circundam a cidade, frequência das pessoas nos locais e, destacando-se a distância entre si. Os parques do estudo são: Anhanguera, Ibirapuera, Santo Dias e Shangrilá (Figura 6). 


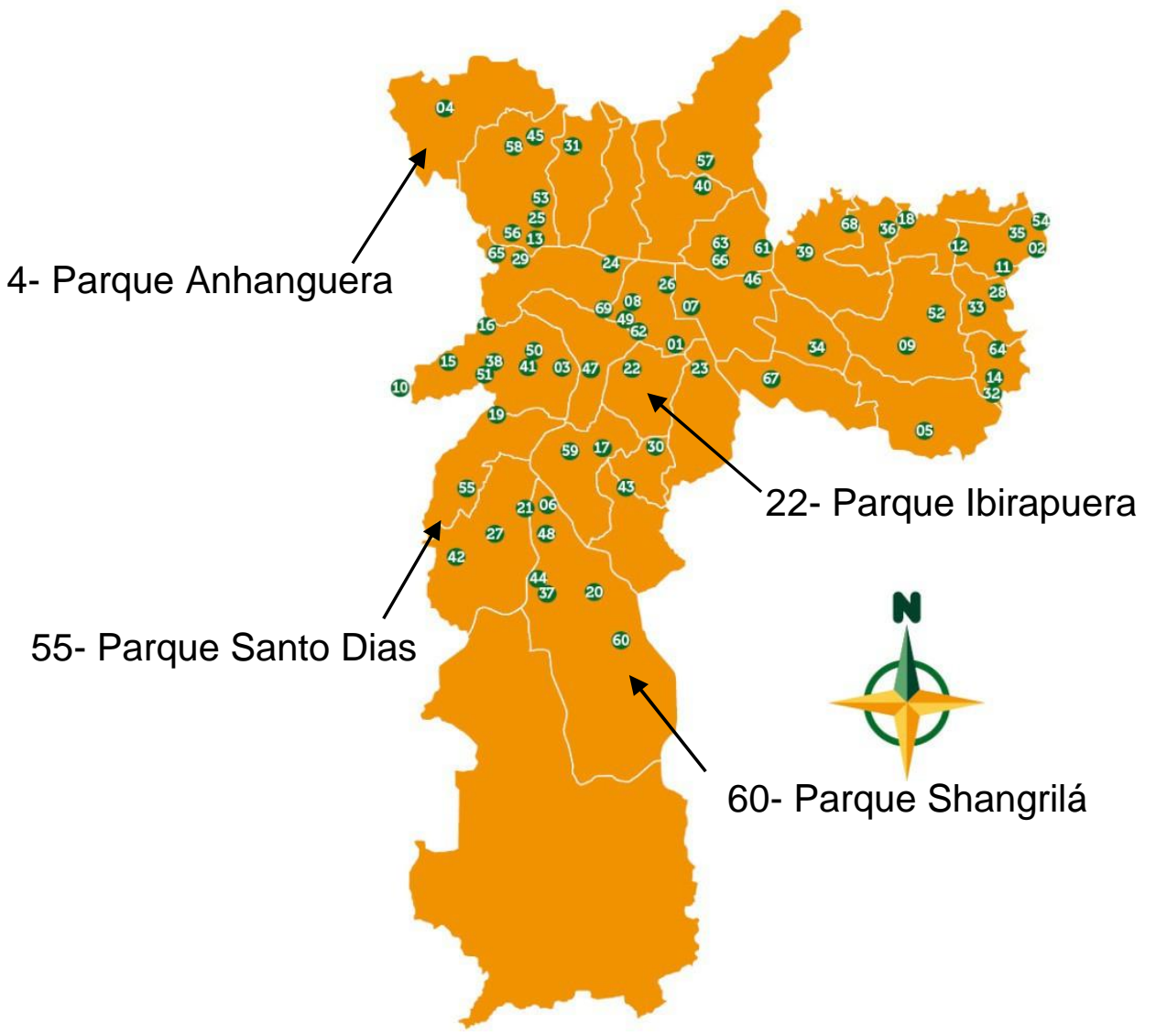

Figura 6 - Mapa da cidade de São Paulo com a localização dos parques municipais de interesse, denominada por números .Fonte: www.prefeitura.sp.gov.br/cidade/secretarias/meio_ambiente/parque

\subsection{ESTUDO DA PAISAGEM}

A Geografia clássica define o espaço como uma porção da superfície com grandes diferenciações na sua composição: os locais denominados mosaicos espaciais. Nesses locais há adequação dos elementos físicos da natureza adaptados ao ser humano para compor o "espaço social". É neste modelo que o conceito de paisagem surge com uma mescla entre os elementos físicos e sociais. Para DOLFFUS (1982), paisagem é uma resultante das transformações ambientais ocorridas devido às relações entre o meio natural e o social, como expressão das intervenções contínuas no meio em que o ser humano vive e 
produz, de acordo com as necessidades do grupo e influências do contexto histórico.

Dentro das transformações ambientais, o termo fragmentação florestal está envolvido com processos de perda de habitat e alterações na qualidade do ambiente que atuam sobre a biodiversidade, em escala espacial. Pode ser definida como uma subdivisão contínua do habitat, resultando em espaços remanescentes da paisagem (FAHRIG, 2003).

As relações entre doenças tropicais e fragmentação da paisagem vegetal são abordadas por uma área denominada Epidemiologia de Paisagens. Segundo ARAGÃO (1988), a Epidemiologia paisagística utiliza todos os aspectos ecológicos dos focos. Neste tipo de abordagem, o epidemiologista, utiliza o conhecimento de algumas condições físicas ambientais, para prever onde se pode esperar o aparecimento de uma doença.

A transformação de uma área de floresta em pequenos fragmentos, pode trazer diversas consequências tais como: a substituição de algumas espécies de plantas e animais (perda de habitat), o favorecimento de espécies mais resilientes (mais resistentes e algumas estranhas ao ecossistema), diminuição no tamanho dos fragmentos, aumento na distância entre os fragmentos e aumento de borda, entre outros problemas (REED, 1996).

Um ambiente alterado, além de favorecer a propagação e a dispersão de vetores e espécies-reservatórios de agentes patogênicos, pode também aumentar a prevalência de patógenos devido ao efeito de diluição (MCCALLUM, 2008; OGRZEWALSKA et al, 2011).

A hipótese do efeito de diluição defende que a biodiversidade diminui 0 risco de doenças infecto-contagiosas. Com uma biodiversidade mais intensa as chances de um vetor encontrar um hospedeiro altamente capaz de transmitir um patógeno é reduzida, devido a provável diluição deste patógeno na natureza. Uma redução da biodiversidade teria um efeito contrário (JOHNSON \& THIELTGES, 2010; OSTFELD \& KEESING, 2012; MILLER \& RUPPERT, 2013).

As pesquisas que relacionam o impacto das características da paisagem às doenças que afetam os seres humanos e animais aumentam constantemente, em função da melhor coleta e análise de dados, pelos avanços na tecnologia como o georreferenciamento e o sensoriamento remoto (a bordo 
de satélites ou em aeronaves), por exemplo. A análise do espaço geográfico atualmente é particularmente interessante nos estudos em questão, pois há uma percepção maior da importância do meio ambiente sobre a existência da humanidade (SILVA \& SCHRAMM, 1997).

O cenário mundial de emergência e reemergência de doenças infecciosas intensificou os esforços incansáveis de epidemiologistas, profissionais das ciências biomédicas e veterinários, bem como de cientistas agrícolas no diagnóstico e tratamento de doenças infecciosas humanas, não-humanas e vegetais, revelando uma postura interdisciplinar correlata. A finalidade desta relação é entender a interação entre patógeno e a espécie hospedeira. Uma vez infectada, a espécie hospedeira pode transmitir o agente patogênico para uma espécie vetor, um mosquito, por exemplo. Por tanto, a compreensão da dinâmica das doenças infecciosas envolve um entendimento sobre o complexo sistema de interação entre os organismos diretamente envolvidos na transmissão das doenças (MACHADO \& RAMOS, 2013).

Os fragmentos de vegetação, originais ou não, que são as áreas verdes das grandes cidades, podem apresentar algumas características importantes como a falta de inimigos naturais e a presença de plantas exóticas. Estes dois fatores podem contribuir para o aumento do número e a disseminação do número de pragas. Quando se busca a compreensão da epidemiologia de doenças muito ligadas ao meio ambiente, como a maioria das doenças infecciosas (transmitidas por vetores) o espaço deve necessariamente entrar na análise para uma avaliação mais acurada do problema estudado (MACHADO \& RAMOS, 2013). 


\section{2- OBJETIVOS}

\subsection{GERAL}

* Estudar a riqueza de espécies de culicídeos de 4 parques distintos da cidade de São Paulo e correlacionar com a paisagem.

\subsection{ESPECÍFICOS}

* Correlacionar os dados obtidos com as características da fauna de Culicidae dos parques amostrados no estudo;

* Verificar indícios de presença de complexos de espécies dentro de alguns gêneros selecionados de culicídios;

* Examinar as distâncias filogenéticas entre os gêneros e espécies de mosquitos estudados;

* Avaliar o uso do marcador molecular COI, para a identificação filogenética e comparar com alguns marcadores mais utilizados em Entomologia,

* Descrever a paisagem dos parques do estudo. 


\section{3- MATERIAL E MÉTODOS}

\subsection{LOCAIS DE ESTUDO}

Este estudo foi realizado com mosquitos adultos capturados (entre outubro 2010 e fevereiro de 2011), nos parques municipais , Anhanguera, Ibirapuera, Santo Dias e Shangrilá, administrados pela Prefeitura da Cidade de São Paulo. Os quatro parques são descritos a seguir:

\subsubsection{PARQUE ANHANGUERA}

Localizado no extremo norte da capital, coordenadas 23 25'6"S,4646'53"W, na Avenida Fortunata Tadiello Natucci, número 1000, no bairro do Perus (km 26 da Rodovia Anhanguera e próximo ao Pico do Jaraguá), conhecido no século XIX como fazenda Ajuá, uma das maiores nas redondezas da capital (PONCIANO, 2004).

O distrito do parque Anhanguera originou-se próximo a rodovia que leva o mesmo nome. O parque propriamente dito surgiu através de uma antiga fazenda de reflorestamento, que foi adquirida pela prefeitura da cidade de São Paulo, em 1978, o Sítio Santa Fé (ÁREAS VERDES DAS CIDADES, 2012) E somente inaugurado um ano depois (A FORMAÇÃO DO TERRITÓRIO DE SÃO PAULO, 2010-13).

O parque tem uma área total de $9.500 .000 \mathrm{~m}^{2}$, sendo $400.000 \mathrm{~m}^{2}$ para visitação pública e o restante que é fechado ao público externo, fica restrito a estudos, pesquisas e preservação ambiental (GUIA DOS PARQUES MUNICIPAIS DE S. PAULO- SMVMA, 2014) (Figura 7).

A área norte é circundada pelo Rio Juqueri, as bordas leste e sudoeste, pelas rodovias Bandeirantes e Anhanguera, respectivamente. É uma das maiores áreas verdes da cidade, com vegetação remanescente da Mata Atlântica (PLETSCH, 2013). 
O nome "Anhanguera" foi o apelido dado pelos indígenas a Bartolomeu Bueno da Silva, um dos bandeirantes. Significa "Espírito Maligno", "Diabo Velho ou "diabo que não tem tanto poder maléfico" (DICIONÁRIO INFORMAL, 2009). $O$ apelido surgiu, pois o bandeirante ameaçou os índios que iria atear fogo na água de todos os rio da região, se não entregassem o ouro que tinham. Como estratégia de convencimento, colocou aguardente num prato e ateou fogo. Os índios ficaram apavorados e entregaram o ouro (PONCIANO, 2004).

O parque apresenta uma fauna exuberante, com cerca de 230 espécies, sendo 146 composta por aves, mais de 15 espécies de anfíbios anuros, como: serpentes, lagartos e cágados. Já em relação às espécies de mamíferos há furões, quatis, cuícas, preás, veados, morcegos, tatus, capivaras e, já foram registrados suçuarana, jaguatirica e canídeos. Espécies ameaçadas de extinção (GUIA DOS PARQUES MUNICIPAIS DE S. PAULO- SMVMA, 2014).

Quanto à flora estão registradas 204 espécies, dentre elas muitas árvores, arbustos e folhagens; várias ameaçadas de extinção. Ao longo de brejos, campos e cursos d'água, há áreas com vegetação remanescente da Mata Atlântica. Considerado importante como corredor ecológico, pois conecta fauna e flora do Parque da Cantareira com a do Parque do Jaraguá (GUIA DOS PARQUES MUNICIPAIS DE S. PAULO- SMVMA, 2014).

Em relação à fauna de mosquitos, destacam-se as espécies: Anopheles (Anopheles) fluminensis (Root), An. (Nyssorhynchus) albitarsis (Lynch Arriba' Izaga), An. (Nys.) evansae (Bre'thes), An. (Nys.) strodei (Root), Ae. (Och.) scapularis (Rondani), Ae. (Stegomyia) aegypti (Linnaeus), Ae. (Stg.) albopictus (Skuse), Culex (Culex) bidens (Dyar), Cx. (Cux.) coronator (Dyar and Knab), Cx. (Cux.) nigripalpus (Theobald), Cx. (Cux.) quinquefasciatus (Say) e Limatus durhamii (Theobald) (MEDEIROS-SOUSA et al, 2013).

A infraestrutura do parque conta com anfiteatro, playgrounds, pista de caminhada, espelho d'água, Centro de Reabilitação de Animais Silvestres na área de visitação restrita, ciclovia, sanitários adaptados, churrasqueiras, trilha, pista de cooper.

Dentre as atividades propostas há o Bosque da Leitura realizado pela Secretaria de Cultura todos os domingos para os visitantes. 


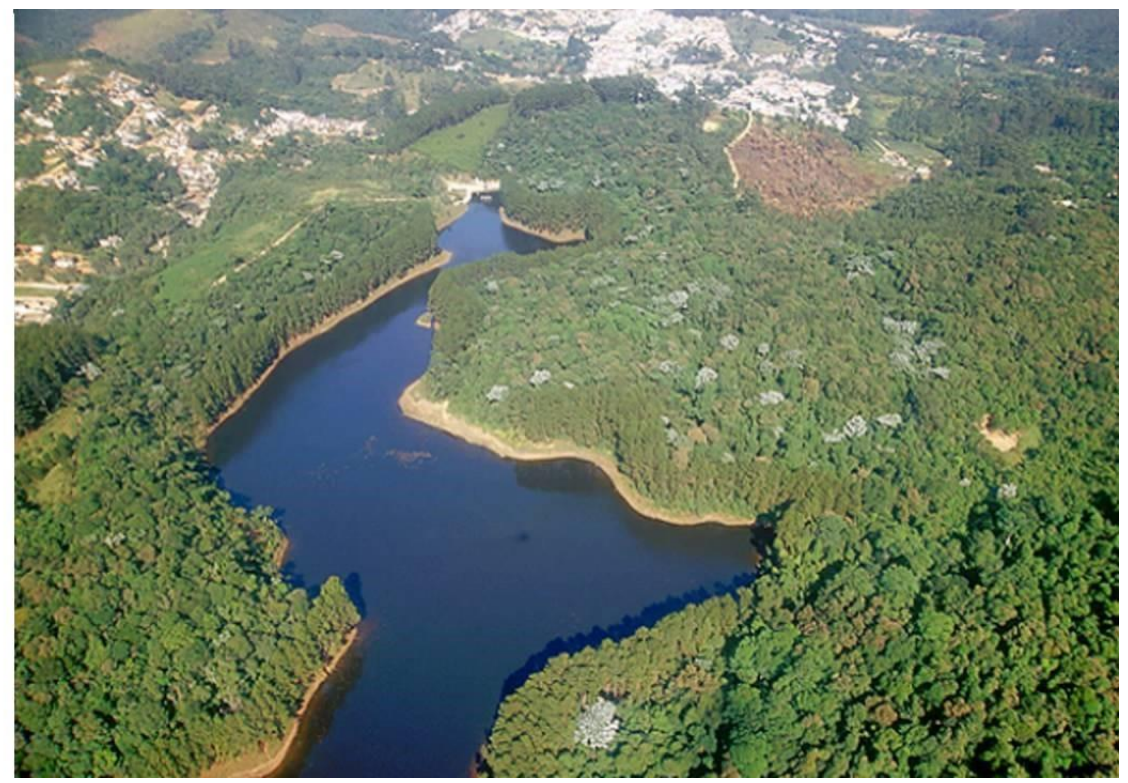

Figura 7- Parque Anhanguera. Vista aérea. Fonte: https://www.google.com.br

\subsubsection{PARQUE DO IBIRAPUERA}

É um dos cenários mais famosos de São Paulo, ficando entre os primeiros da lista dos mais frequentados pelos paulistanos e turistas (Figura 8). Localizado na zona central da cidade, na Avenida Pedro Álvares Cabral s/n, coordenadas $233^{\prime \prime} 18^{\prime \prime} \mathrm{S}, 46^{\circ} 39^{\prime} 32^{\prime \prime} \mathrm{W}$, no bairro da Vila Mariana. Região de tradição, atraente e moderna, com ares de classe média alta e com uma extensa e badalada vida cultural (PONCIANO, 2012).

Foi inaugurado no dia 21 de agosto de 1954 no IV Centenário de São Paulo (para comemorar os 450 anos da cidade e dar mais destaque à festa). $O$ seu projetista foi o arquiteto paisagista Augusto Teixeira Mendes. O famoso arquiteto Oscar Niemeyer, também participou do projeto, criando o núcleo de edificações da centralidade cultural composto pela Oca, Auditório, Bienal, Museu Afro e a Marquise (GUIA DOS PARQUES MUNICIPAIS DE S. PAULO- SMVMA, 2014).

Os visitantes do site Trip Advisor o elegeram em junho de 2013, como o melhor parque da América do Sul. Em 2015, foi considerado pelo jornal inglês The Guardian, um dos dez maiores espaços verdes urbanos do mundo (THE GUARDIAN, 2015). 


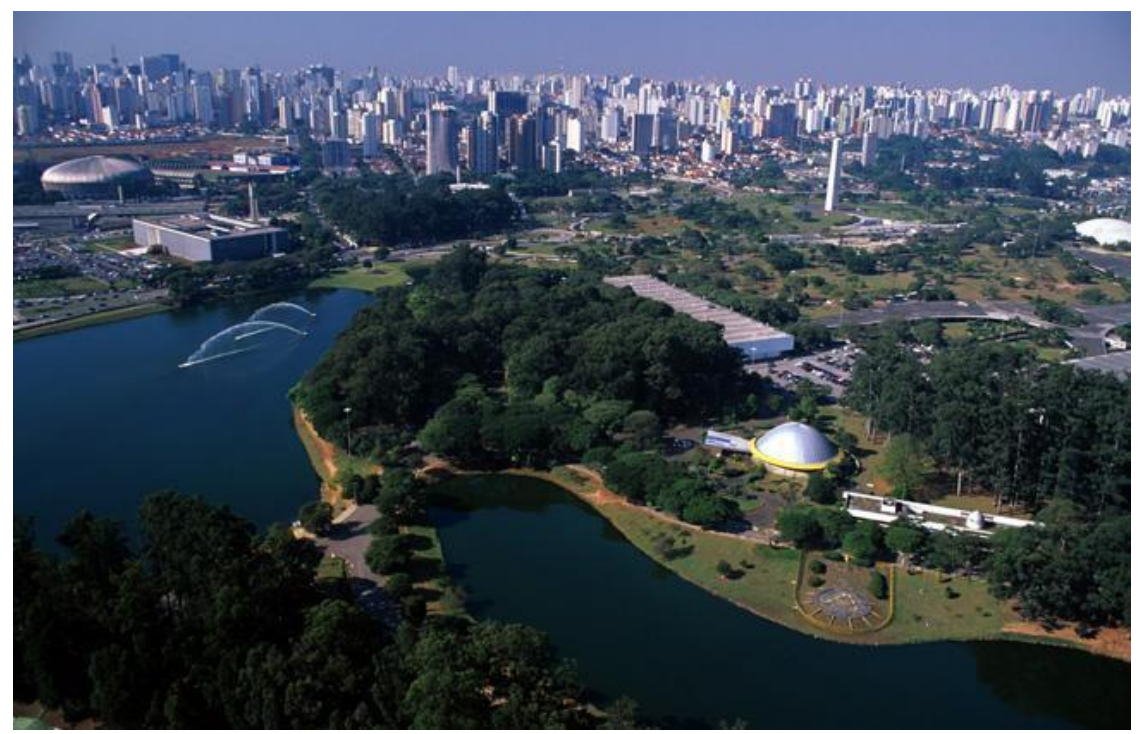

Figura 8- Parque do Ibirapuera. Vista aérea. Fonte: https://www.tripadvisor.com.br

Apresenta uma fauna com 218 espécies dentre elas, na sua maioria, composta por pássaros. Mas também há répteis, peixes, borboletas, mamíferos e uma única espécie de anfíbio. Quanto à flora, há espécies nativas e algumas espécies de vegetação implantada: árvores, gramados, etc. (GUIA DOS PARQUES MUNICIPAIS DE S. PAULO- SMVMA, 2014).

Quanto à fauna de mosquitos, destacam-se: Ae. (Och.) scapularis (Rondani), Ae. (Stegomyia) aegypti (Linnaeus), Ae. (Stg.) albopictus (Skuse), Culex (Culex) bidens (Dyar)r, Cx. (Cux.) coronator (Dyar and Knab), Cx. (Cux.) declarator (Dyar and Knab), Cx. (Cux.) grupo coronator (Dyar and Knab) e Cx. (Cux.) nigripalpus (Theobald) (MEDEIROS-SOUSA et al, 2013).

Com uma área total de $1.584 .000 \mathrm{~m}^{2}$, apresenta excelente infraestrutura com pista de Cooper, campos de futebol, lanchonetes, ciclovias, Planetário, Escola Municipal de Astrofísica, dentre outros. Dentre as atividades propostas, estão a Escola de Jardinagem e o Bosque da Leitura. O nome "Ibirapuera", em Tupi-guarani Ypy-ra-ouêra = significa "pau podre" ou "árvore apodrecida" (DICIONÁRIO ILUSTRADO TUPI GUARANI, 2016). 


\subsubsection{PARQUE SANTO DIAS}

O Parque Santo Dias (Figura 9) está localizado na Travessa Jasmim da Beirada, 71 (Portão I) e Rua Arroio das Caneleiras, s/n (Portão II), no bairro do Capão Redondo, Subprefeitura do Campo Limpo. Nas coordenadas 2339'49.1"S 4646'23.7"W, zona sul da capital.

O seu nome foi dado em homenagem a um morador do bairro Capão Redondo, que foi morto durante a greve dos trabalhadores em 1979. Originou-se da antiga fazenda do Instituto Adventista (IAE), onde funcionava o seminário Adventista. A mesma foi desapropriada para a construção da COHAB Adventista. Nessa mesma época a comunidade, através da associação de moradores, reinvindicou a construção do parque e a administração municipal concordou. O parque Santo Dias foi inaugurado em 07 de novembro de 1992 (ÁREAS VERDES DAS CIDADES, 2014).

A fauna do parque Santo Dias é composta por 84 espécies descritas até 0 momento. Destas, 75 são de aves e há alguns mamíferos A flora é constituída de árvores, especiarias, palmeiras, dentre outras (ÁREAS VERDES DAS CIDADES, 2014/ GUIA DOS PARQUES MUNICIPAIS DE S. PAULO- SMVMA, 2014).

Em relação à fauna de mosquitos, as espécies em destaque são: $A e$. (Och.) scapularis (Rondani), Ae. (Stegomyia) aegypti (Linnaeus), Ae. (Stg.) albopictus (Skuse), Cx. (Cux.) chidesteri (Dyar), Cx. (Cux.) declarator (Dyar and Knab), Cx. (Cux.) lygrus (Root), Cx. (Cux.) nigripalpus (Theobald), Cx. (Cux.) quinquefasciatus (Say), Cx. (Cux.) spp. (Linnaeus), Cx. (Mcx.) imitator imitator (Theobald), Wyeomyia (Phoniomyia) galvaoi (Corrêa and Ramalho) e Tx. spp. (Theobald) (MEDEIROS-SOUSA et al, 2013).

A infraestrutura é composta por várias estruturas de lazer, como quadras de esportes, quiosque para prática de ginástica, pista de Cooper, academia da terceira idade, viveiro de mudas, viveiro de plantas medicinais, conta com um CECCO (Centro de Convivência e Cooperativa), onde são desenvolvidas várias atividades esportivas com o tênis em destaque e as educativas, como o 
"Bosque da Leitura" (programa da Secretaria Municipal da Cultura). Há também uma nascente com um lago pequeno.

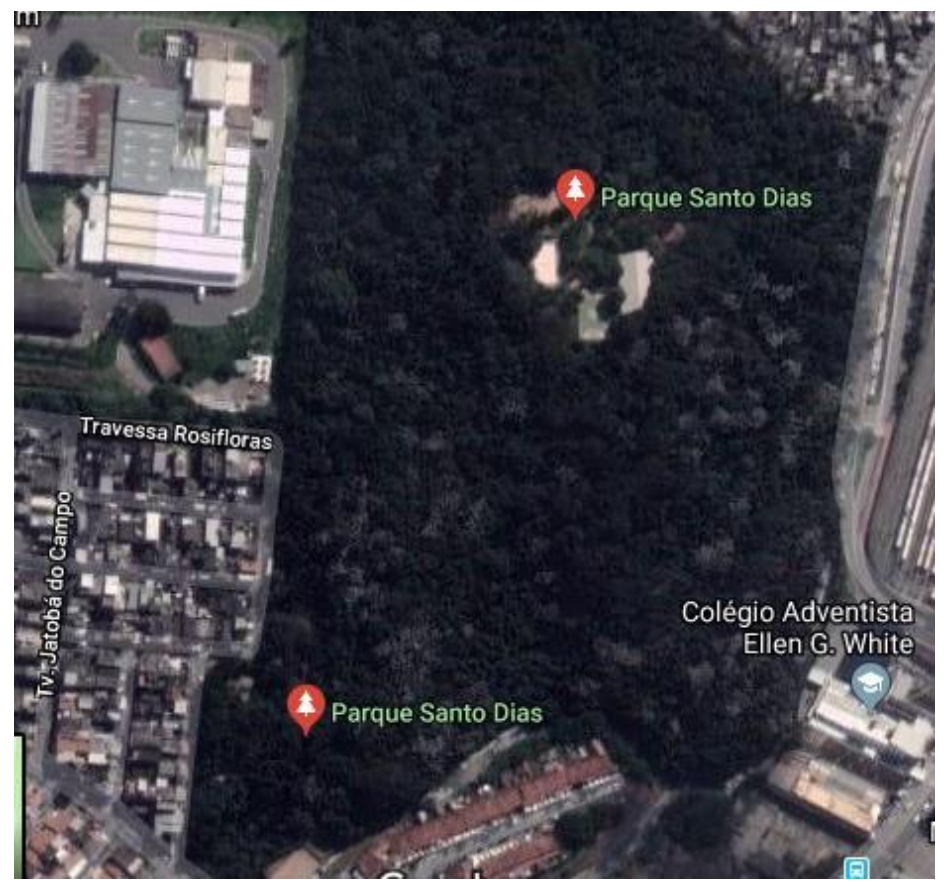

Figura 9- Parque Santo Dias. Vista aérea Fonte:www.google.com.br/maps

\subsubsection{PARQUE SHANGRILÁ}

O parque Shangrilá (Figura 10) está localizado na Rua irmã Maria Lourença, número 250, no bairro do Grajaú, tipicamente paulistano dos novos tempos, muito populoso e com cerca de 50.000 pessoas vivendo em favelas (SÃO PAULO BAIRROS, 2018). Pertence à Subprefeitura da Capela do Socorro, na Zona Sul de São Paulo.

Com uma área de $75.000 \mathrm{~m}^{2}$, o parque fica localizado dentro da Área de Proteção Ambiental Bororé-Colônia, próximo à Represa Billings.

A história do parque começa com a ideia da prefeitura de proteger a represa, quando adquiriu áreas verdes estratégicas para preservar o patrimônio da cidade e da biodiversidade, auxiliando no enriquecimento da vida biológica. 
Foi inaugurado em 19 de agosto de 2008 (ÁREAS VERDES DAS CIDADES, 2014).

Quanto à fauna, foram registradas 109 espécies, dentre elas: aves, mamíferos e répteis. Em destaque para borboletas, com 16 espécies A flora é composta por árvores, arbustos e gramados (GUIA DOS PARQUES MUNICIPAIS DE S. PAULO- SMVMA, 2014). A fauna de mosquitos apresenta as seguintes espécies: Aedes (Ochlerotatus) fluviatilis (Lutz), Ae. (Och.) scapularis (Rondani), Ae. (Stg.) albopictus (Skuse), Culex (Culex) bidens (Dyar), Cx. quinquefasciatus, Cx. (Cux.) chidesteri (Dyar), Cx. (Cux.) declarator (Dyar and Knab), Cx. (Cux.) lygrus (Root), Cx. (Cux.) nigripalpus (Theobald), Cx. (Cux.) spp.(Linnaeus) e Limatus durhamii (Theobald) (MEDEIROS-SOUSA et al, 2013).

A infraestrutura é composta por uma horta, uma área de estar e descanso com mesas e bancos, sanitários, bebedouros, quadra de areia, quadra de futebol com grama sintética, viveiro e playground. Em relação às atividades para a população, há caminhadas das Unidades Básicas de Saúde (UBS) Alcina e da Eliana, acompanhadas por Agentes Comunitários de Saúde, ensino de plantio de mudas, trilhas monitoradas e treinos de futebol feminino. Também compõe o cronograma de práticas do parque, uma lista de atividades permanentes como empréstimo de jogos, coleta de material reciclado, de medicamentos vencidos, de óleo usado, pilhas e baterias (GUIA DOS PARQUES MUNICIPAIS DE S. PAULO- SMVMA, 2014). 


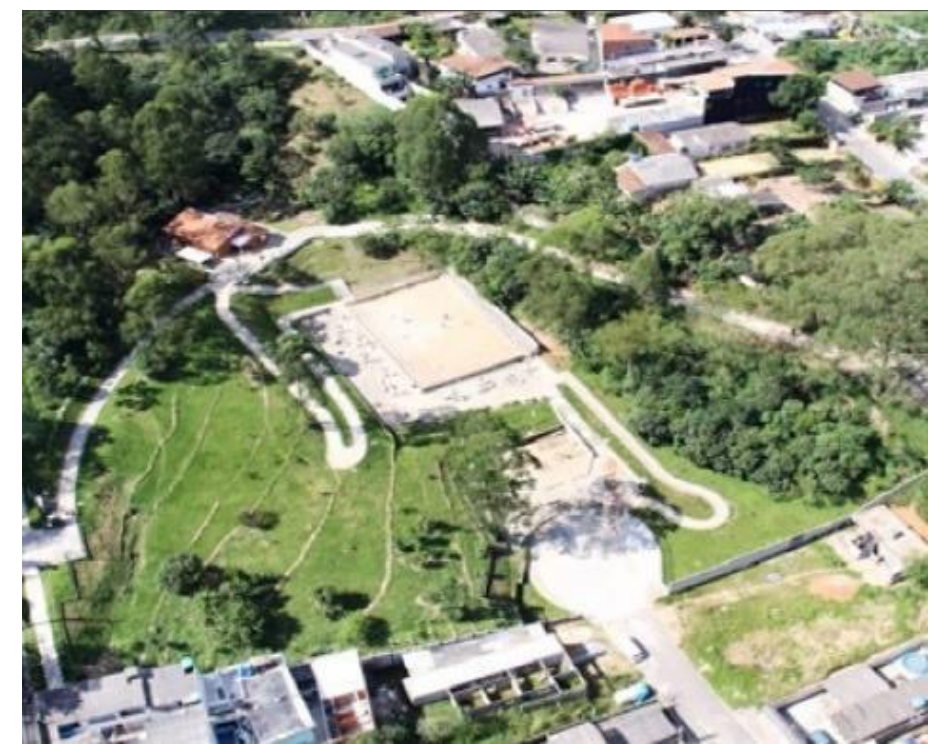

Figura 10- Parque Shangrilá. Vista aérea. Fonte: Guia dos Parques Municipais de São Paulo (SMVMA, 2014 ).

\subsection{CAPTURA DOS MOSQUITOS}

Esse estudo utilizou mosquitos adultos dos parques Anhanguera, Ibirapuera, Santo Dias e Shangrilá, coletados entre outubro de 2010 e fevereiro de 2011. Para a obtenção dos espécimes foram utilizados aspiradores a bateria de $12 \mathrm{~V}$ durante 20 minutos, por $\mathrm{m}^{2}$ (NATAL \& MARUCCI, 1984). Foram feitas de uma a três aspirações por parque, dependendo das dimensões e características ambientais do local (MEDEIROS-SOUSA et al, 2013). Os exemplares foram acondicionados em caixas entomológicas, com papel-filtro e sílicagel, transportados até o Laboratório de Entomologia de Saúde Pública (LESP) da Faculdade de Saúde Pública (FSP) da Universidade de São Paulo.

\subsection{IDENTIFICAÇÃO DOS ESPÉCIMES}

A identificação morfológica baseou-se nas chaves dicotômicas de LANE (1953), CONSOLI \& LOURENÇO-DE-OLIVEIRA (1994) e FORATTINI (2002) e 
as abreviações dos nomes seguiram REINERT (2001). Dois exemplares de cada espécie, de acordo com a frequência das mesmas nos parques, foram acondicionados em microtubos tipo "eppendorff' e congelados à $-20^{\circ} \mathrm{C}$, identificados para uso posterior. Exemplares representativos e informações de cada espécie foram guardados no Laboratório de Entomologia em Saúde Pública (LESP/FSP/USP).

\subsection{EXTRAÇÃO DO DNA GENÔMICO}

A extração do DNA genômico dos espécimes foi feita com o protocolo de extração de DNA de amostras exóticas, de acordo com ALJANABI e MARTINEZ, 1997. O mesmo já foi utilizado para outros artrópodes e leguminosas, demostrando alto rendimento de DNA.

\subsection{REAÇÃO EM CADEIA PELA POLIMERASE (PCR)}

O DNA extraído das amostras foi submetido a uma reação de amplificação, utilizando os primers (iniciadores) descritos na Tabela 2, para a amplificação da região citocromo c oxidase I (fragmento com cerca de 648 pb). As concentrações dos reagentes estão descritas na Tabela 3.

Tabela 2 - Descrição da sequência dos primers utilizados para a amplificação.

\begin{tabular}{l|l}
\hline Primers & Sequência 5' - 3' \\
\hline HCO 2198 BARCODING & TAA ACT TCA GGG TGA CCA AAA AAT CA \\
LCO I 1490 BARCODING & GG T CAA CAA ATC ATA AAG ATA TTG G \\
\hline \hline
\end{tabular}

Fonte: FOLMER et al, 1994 
Tabela 3 - Descrição das condições da reação de PCR.

\begin{tabular}{l|l|l}
\hline REAGENTES $^{*}$ & Mix por tubo & Concentração \\
\hline 5X FIREpol \& Master Mix & $12,5 \mu \mathrm{l}$ & $1 \mathrm{x}$ \\
\hline $\mathrm{HCO}$ I $10 \mu \mathrm{M}$ (forward) & $0,5 \mu \mathrm{l}$ & $0,2 \mu \mathrm{M}$ \\
\hline LCO I $10 \mu \mathrm{M}$ (reverse) & $0,5 \mu \mathrm{l}$ & $0,2 \mu \mathrm{M}$ \\
\hline DNA & $1,0 \mu \mathrm{l}$ & Entre 40 e 80 ng \\
\hline $\mathrm{H}_{2} \mathrm{O}$ ultrapura (deionizada) & $10,5 \mu \mathrm{l}$ & \\
\hline Volume final & $25,0 \mu \mathrm{l}$ & \\
\hline
\end{tabular}

${ }^{*}$ Conforme sugerido pelo fabricante.

O 5X FIREpol ® Master Mix, já contém todos os reagentes necessários para a reação e, o kit utilizado foi da marca Solis BioDyne. O aparelho utilizado foi o termociclador Techne Genius modelo FGEN05TD. Os ciclos de temperatura foram programados para: $1 \mathrm{~min}$. a $94^{\circ} \mathrm{C}$, cinco ciclos de 1 min. a $94^{\circ} \mathrm{C}, 1,5 \mathrm{~min}$ a $45^{\circ} \mathrm{C}$ e $1,5 \mathrm{~min}$. a $72^{\circ} \mathrm{C}$; trinta e cinco ciclos de $1 \mathrm{~min}$. a $94^{\circ} \mathrm{C}, 1,5 \mathrm{~min}$. a $50^{\circ} \mathrm{C}, 1$ min. a $72^{\circ} \mathrm{C}$ e um ciclo final de $5 \mathrm{~min}$. a $72^{\circ} \mathrm{C}$. Para cada uma das reações foi utilizado um controle negativo (água deionizada), garantindo a ausência de contaminações. Como controle positivo foi utilizado $1 \mu \mathrm{l}$ da amostra do espécime Ae. fluviatilis, do parque Anhanguera, que apresentou boa amplificação.

\subsection{ELETROFORESE EM GEL DE AGAROSE}

Os produtos amplificados por PCR foram analisados segundo SAMBROOK et al, 1989 em gel de agarose 1,0 \% (Amresco®), no volume de 50 $\mathrm{ml}$ de tampão TBE. Em cada cavidade foi colocado um volume de $4 \mu \mathrm{l}$ de amostra, $2 \mu$ de Gel red ${ }^{\text {TM }}$ da Uniscience (1:500) e $1 \mu$ de Loading buffer (6X). O marcador de peso molecular utilizado foi o GeneRuler 100 bp DNA Ladder, no volume de $1 \mu \mathrm{l}(0,5 \mu \mathrm{g} / \mu \mathrm{l})$.

O gel com as amostras na cuba horizontal com tampão TBE (1X) foi exposto a uma voltagem de $80 \mathrm{mv}$ por 30 minutos. A visualização dos produtos 
amplificados no gel foi feita em transiluminador de luz ultravioleta modelo ECXF26.MX Vilber Lourmat, assim como a obtenção das fotos dos géis. Os arquivos do aparelho foram salvos em pendrive e no computador.

\subsection{REAÇÃO DE SEQUENCIAMENTO}

Os fragmentos amplificados foram sequenciados usando $A B I$ Prism BigDye Terminator Ready Reaction Kit (Perkin Elmer, Foster City, CA), no sequenciador ABI PRISM 3100 Genetic Analyzer/HITACHI. As condições de sequenciamento estão descritas na Tabela 4.

Tabela 4- Descrição dos reagentes da reação de sequenciamento

\begin{tabular}{l|c|c}
\hline \multicolumn{1}{c|}{ REAGENTES } & Mix por tubo & Concentração \\
\hline Produto de PCR & $40-60 \mathrm{ng}$ & \\
Big Dye & $1,0 \mu \mathrm{l}$ & \\
Tampão & $3,0 \mu \mathrm{l}$ & \\
Primer & $1,0 \mu \mathrm{l}$ & $3,6 \mu \mathrm{M} / \mu \mathrm{l}$ \\
$\mathrm{H}_{2} \mathrm{O}$ ultrapure (deionizada) & $\mathrm{qsp}$ & \\
Volume final & $15 \mu \mathrm{l}$ & \\
\hline
\end{tabular}

${ }^{*}$ Conforme sugerido pelo fabricante.

Após o sequenciamento, a cada reação foram adicionados $5 \mu$ de EDTA $(125 \mathrm{mM})$ e $60 \mu \mathrm{l}$ de etanol absoluto. Vórtex por 15 segundos, incubadas à temperatura ambiente por $15 \mathrm{~min}$. E centrifugadas por $30 \mathrm{~min}$. A $2.173 \mathrm{~g}$. A cada amostra foi adicionado $60 \mu \mathrm{l}$ de etanol $70 \%$, centrifugado a $1.650 \mathrm{~g}$, por $15 \mathrm{~min}$. Ao sobrenadante foi adicionado $10 \mu \mathrm{l}$ de formamida para o sequenciamento. 


\subsection{ANÁLISE DAS SEQUÊNCIAS}

As sequências COI foram editadas e alinhadas com Geneious R11 Coyright(C) 2005-2018 Biomatters Ltd., e analisadas através da ferramenta BLAST (Basic Local Alignment Search Tool) do site http://blast.ncbi.nlm.nih.gov/blast.cgi (MOUNT, 2007). Cada espécime foi sequenciado em média 4 vezes usando os primers, senso e anti-senso, evitando possíveis taxas de erros de sequenciamento (BLAXTER, 2004). Para alguns espécimes, devido ás dificuldade no sequenciamento, foi feito um maior número de tentativas sem sucesso.

Nos sítios que apresentaram problemas de leitura, ou no caso de dúvida nas bases nitrogenadas, foram utilizados os perfis dos eletroferogramas. Este método, juntamente com os alinhamentos das sequências no BLAST, as questões foram resolvidas.

\subsection{PAISAGEM DOS PARQUES}

Em cada uma das quatro áreas selecionadas para o estudo, imagens de satélite foram geradas por meio do aplicativo Google Earth Pro (Satélite Landsat), sendo esse mesmo aplicativo utilizado para o cálculo das métricas, foram mensurados as seguintes variáveis, conforme UEZU et al, 2005:

Área de floresta $5 \mathrm{~km}$ : Quantidade de floresta, em hectares, situados dentro do raio delimitado de $5 \mathrm{~km}$ a partir da borda do fragmento principal. Fragmentos com pequenas distâncias entre si (máximo de $100 \mathrm{~m}$ ) também serão incluídos no cálculo, pois apesar de não haver uma conexão estrutural (física) entre os fragmentos, há uma conexão funcional. Área de floresta $10 \mathrm{~km}$ : Como objetivo de mensurar a conectividade da floresta, cada área de estudo terá a área florestal mensurada em um raio de $10 \mathrm{~km}$ a partir do centro do fragmento estudado. $O$ raio de $10 \mathrm{~km}$ foi determinado com o objetivo de mensurar se a quantidade de floresta presente em cada área apresentaria um incremento ou permaneceria a mesma em relação a área de floresta no raio de 5 km (UEZU et al, 2005). 
A menor distância entre as bordas dos fragmentos florestais foram mensuradas em mapas do Sistema de Informação Florestal do Estado de São Paulo (SIFESP), e as distâncias da mais provável conexão funcional entre os fragmentos intercalados por áreas urbanas foram também mensurados. A conexão funcional foi considerada provável onde fragmentos florestais estão separados uns dos outros por distâncias não superiores a 100 metros de áreas de florestadas. As métricas foram calculadas no programa BaseCamp 4.5.2 (Garmin $\left.\AA^{8}\right)$. 


\section{4- RESULTADOS}

\subsection{ESPÉCIMES DO ESTUDO}

Tabela 5- Espécies dos mosquitos adultos coletados por parque (nomenclatura tradicional, autores e respectivos anos de identificação) no município de São Paulo, selecionados para o estudo. Período de 2010 até 2011:

\begin{tabular}{|c|c|c|c|}
\hline Anhanguera & Ibirapuera & Santo Dias & Shangrilá \\
\hline $\begin{array}{l}\text { + Aedes (Stegomyia) } \\
\text { albopictus (Skuse, } \\
\text { 1895) } \\
\text { + Aedes } \\
\text { (Ochlerotatus) } \\
\text { crinifer (Theobald, } \\
\text { 1903) } \\
\text { + Aedes } \\
\text { (Ochlerotatus) } \\
\text { fluviatilis (Lutz, } \\
\text { 19f03) } \\
\text { + Aedes } \\
\text { (Ochlerotatus) } \\
\text { scapularis (Rondani, } \\
\text { 1848) } \\
\text { + Anopheles } \\
\text { (Nyssorhynchus) } \\
\text { strodei (Root, 1926) } \\
\text { + Culex (Culex) sp. } \\
\text { + Coquillettidia } \\
\text { (Rhynchotaenia) } \\
\text { venezuelensis } \\
\text { (Theobald, 1912) } \\
\text { + Haemagogus } \\
\text { (Conopostegos) } \\
\text { leucocelaenus (Dyar } \\
\text { \& Shannon, 1924) } \\
\text { + Psorophora } \\
\text { (Janthinosoma) } \\
\text { ferox (Von } \\
\text { Humboldth, 1819) }\end{array}$ & $\begin{array}{l}+ \text { Aedes (Ste.) } \\
\text { albopictus } \\
+ \text { Aedes (Och.) } \\
\text { scapularis } \\
+ \text { Culex (Culex) } \\
\text { declarator (Dyar \& } \\
\text { Knab, 1906) } \\
+ \text { Culex dolosus } \\
\text { (Lynch } \\
\text { Arribálzaga, 1891) } \\
+ \text { Culex (Culex) } \\
\text { quinquefasciatus } \\
\text { (Say, 1823) } \\
+ \text { Culex (Culex) } \\
\text { grupo Coronator } \\
+ \text { Mansonia } \\
\text { (Mansonia) titilans } \\
\text { (Walker, 1848) } \\
+ \text { Toxorhynchites } \\
\text { bambusicolus } \\
\text { (Lutz \& Neiva } \\
\text { 1913) } \\
+ \text { Toxorhynchites } \\
\text { sp. }\end{array}$ & $\begin{array}{l}\text { + Aedes } \\
\text { (Stegomyia) } \\
\text { aegypti (Linnaeus, } \\
\text { 1762) } \\
\text { + Aedes (Ste.) } \\
\text { albopictus } \\
\text { + Aedes (Och.) } \\
\text { scapularis } \\
\text { + Anopheles } \\
\text { (Nyssorhynchus) } \\
\text { evansae (Brètes, } \\
\text { 1926) } \\
\text { + Culex (Culex.) } \\
\text { chidesteri (Dyar, } \\
\text { 1921) } \\
\text { + Culex (Cx.) } \\
\text { declarator } \\
\text { + Culex } \\
\text { (Microculex) imitator } \\
\text { (Netto, 1940) } \\
\text { + Culex (Culex) } \\
\text { nigripalpus } \\
\text { (Theobald, 1901) } \\
\text { + Limatus durhami } \\
\text { (Theobald, 1901) } \\
\text { + Wyeomyia } \\
\text { (Phoniomyia)sp. }\end{array}$ & $\begin{array}{l}\text { + Aedes (Ste.) } \\
\text { albopictus } \\
\text { + Aedes (Och.) } \\
\text { fluviatilis } \\
\text { + Culex (Cx.)chidesteri } \\
\text { + Culex(Melanoconion) } \\
\text { ribeirensis (Forattini \& } \\
\text { Sallum, 1985) } \\
\text { + Culex saltanensis } \\
\text { + Limatus durhami } \\
\text { + Mansonia(Mansonia) } \\
\text { indubitans (Dyar \& } \\
\text { Shannon, 1925) } \\
\text { + Mansonia (Mansonia) } \\
\text { wilsoni (Barreto \& } \\
\text { Coutinho, 1944) } \\
\text { +Toxorhynchites sp. } \\
\text { +Uranotaenia } \\
\text { (Uranotaenia) lowii } \\
\text { (Theobald, 1901) }\end{array}$ \\
\hline
\end{tabular}




\subsection{AMPLIFICAÇÃO E QUANTIFICAÇÃO DO DNA}

O material produzido por PCR foi aplicado em gel de agarose, com $4 \mu \mathrm{l}$ do marcador de massa molecular Low DNA Mass Ladder da Invitrogen ${ }^{\mathrm{TM}}$, o qual além de quantificar o material de até $200 \mathrm{ng}$, propicia a verificação do tamanho do fragmento até a marca de 2.000 pares de bases. Os fragmentos amplificados são menores que 800 pares de bases, apresentaram diferenças na intensidade da amplificação e alguns espécimes não amplificaram, como pode ser observado na Figura 11.

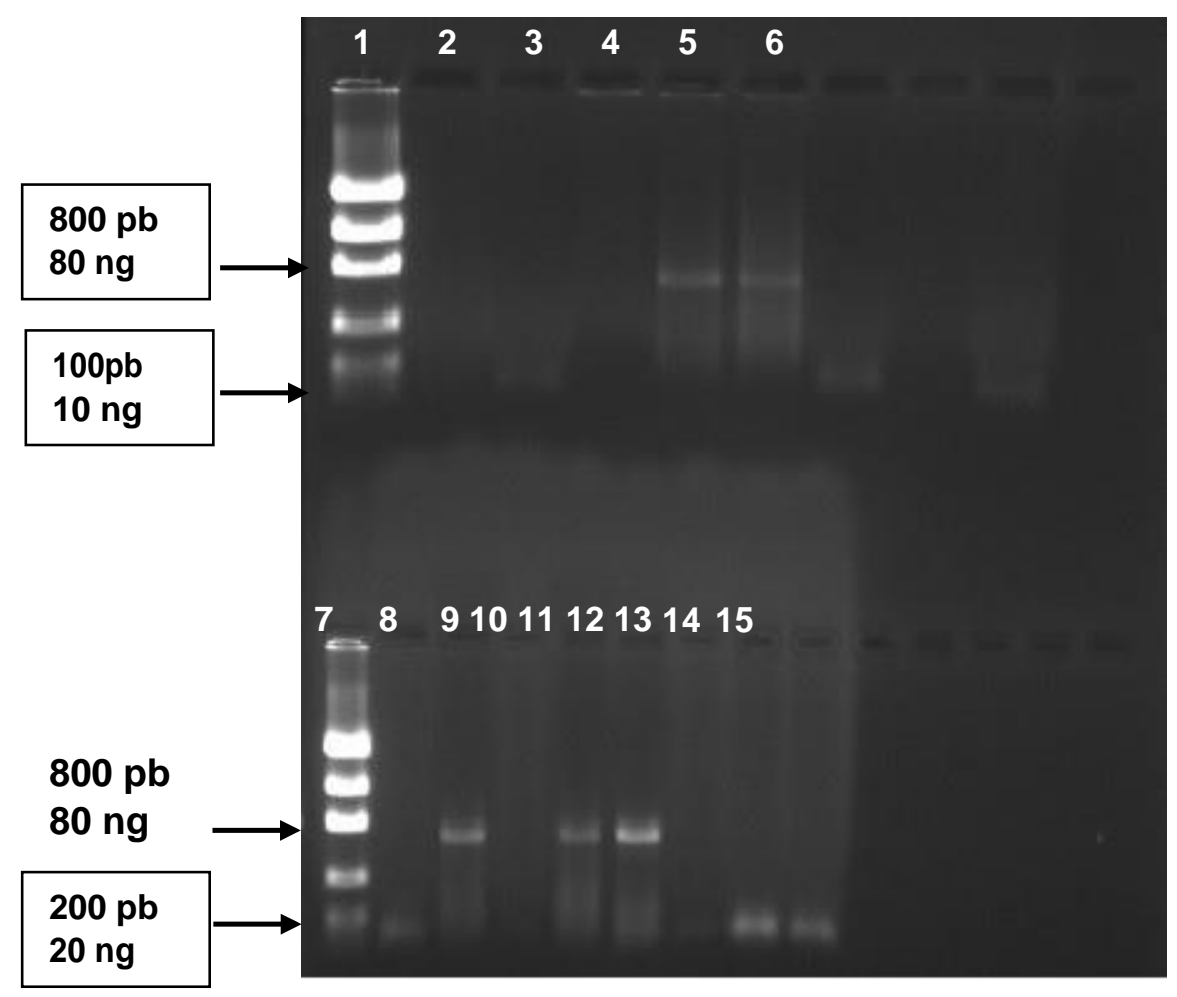

Figura 11- Gel de agarose com amostras do parque Shangrilá: tamanho dos fragmentos amplificados e quantificação do DNA dos produtos de PCR. 1 e 7- marcador Low DNA Mass Ladder (4ul); 2- controle negativo, 3- Ae. albopictus (1ul), não amplificado. 4- Ae. albopictus (4 ul), não amplificado; 5- Culex (Culex) saltanensis (Dyar, 1928), com cerca de 10 ng de DNA. Amplificado, mas não sequenciado; 6- Ur. lowii, com cerca de 10ng de DNA. Amplificado, mas não sequenciado; 8- controle negativo; 9- $C x$. chidesteri, com cerca de 20 ng de DNA (sequenciado).10- Mansonia (Mansonia) indubitans (1ul), não amplificado; 11- Li. durhami, cerca de 20 ng de DNA (sequenciado). 12- An. fluviatilis, cerca de 40 ng de DNA (sequenciado) 13Ma. indubitans (4ul,) não amplificado 14- Ma. indubitans (5ul), não amplificado 15- Ma. indubitans (6ul), não amplificado 


\subsection{SEQUENCIAMENTO DAS AMOSTRAS}

Foram sequenciadas as espécies apresentadas na Tabela 5, distribuídas por parques. As demais espécies apresentadas em negrito não puderam ser sequenciadas, talvez devido à degradação do material (espécime em questão), nas caixas entomológicas. Mesmo após todos os cuidados preconizados para a armazenagem dos mesmos.

\subsection{CARACTERÍSTICAS DAS SEQUÊNCIAS}

Analisando os perfis das sequências obtidas, pode-se observar uma taxa elevada de Adenina (A) e Timina (T). Esta composição está de acordo com o padrão esperado para sequências de DNA mitocondrial descritas na literatura para o grupo dos artrópodes (LESSINGER; AZEREDO-ESPIN, 2000).

\subsection{PORCENTAGEM DE SIMILARIDADE NO BASIC LOCAL ALIGNEMENT SEARCH TOOL (BLAST)}

As sequências obtidas foram comparadas com os perfis dos eletroferogramas, para a confirmação das bases sequenciadas. Foram computadas as porcentagens de similaridade das sequências obtidas, no programa Geneious e as mesmas foram alinhadas com as sequências depositadas no GenBank®. As espécies referentes a essas similaridades também foram citadas, assim como o número de acesso de cada uma e o tamanho do fragmento sequenciado, por espécie trabalhada no estudo e por parque. As anotações foram dispostas nas Tabelas 6, 7, 8 e 9 para melhor visualização e análise posterior, como segue. 
Tabela 6- Descrição das porcentagens de similaridade das sequências das espécies se mosquitos do Parque Anhanguera, do Município de São Paulo, obtidas em novembro de 2018:

\begin{tabular}{|c|c|c|c|}
\hline Espécime & $\begin{array}{c}\text { Espécie e número } \\
\text { do GenBank® }\end{array}$ & $\%$ similaridade & $\begin{array}{c}\text { Tamanho do } \\
\text { fragmento }\end{array}$ \\
\hline Ae. albopictus & $\begin{array}{l}\text { Ae.albopictus } \\
\text { MF148292.1 }\end{array}$ & $100 \%$ & $568 \mathrm{pb}$ \\
\hline Ae. crinifer & $\begin{array}{l}\text { Ochlerotatus crinifer } \\
\text { HE605118.1 }\end{array}$ & $97 \%$ & $589 \mathrm{pb}$ \\
\hline Ae. fluviatilis & $\begin{array}{l}\text { Ochlerotatus } \\
\text { fluviatillis } \\
\text { KF314738.1 }\end{array}$ & $100 \%$ & $649 \mathrm{pb}$ \\
\hline Ae. scapularis & $\begin{array}{l}\text { Ochlerotatus } \\
\text { scapularis } \\
\text { KM115446.1 }\end{array}$ & $100 \%$ & $533 \mathrm{pb}$ \\
\hline$C x . s p$ & $\begin{array}{l}\text { Culex (Culex) } \\
\text { eduardoi (Casal \& } \\
\text { Garcia, 1968) } \\
\text { KF919217.1 }\end{array}$ & $99 \%$ & $499 \mathrm{pb}$ \\
\hline Cq. venezuelensis & $\begin{array}{l}\text { Coquillettidia } \\
\text { nigricans } \\
\text { KY859872.1 }\end{array}$ & $95 \%$ & $571 \mathrm{pb}$ \\
\hline Hg.leucocelaenus & $\begin{array}{l}\text { Hg. leucocelaenus } \\
\text { MG242532.1 }\end{array}$ & $98 \%$ & $581 \mathrm{pb}$ \\
\hline
\end{tabular}

A espécie $C q$. venezuelensis, destacada em negrito apresentou baixa taxa de similaridade (95\%) com a sequência mais próxima, a espécie Cq. nigricans alinhada pelo GenBank®. 
Tabela 7- Descrição das porcentagens de similaridade das sequências das espécies de mosquitos do Parque lbirapuera, do Município de São Paulo em novembro de 2018:

\begin{tabular}{|c|c|c|c|}
\hline Espécime & $\begin{array}{c}\text { Espécie e número do } \\
\text { GenBank }{ }^{\circledR}\end{array}$ & $\%$ similaridade & $\begin{array}{c}\text { Tamanho do } \\
\text { fragmento }\end{array}$ \\
\hline Ae. albopictus & $\begin{array}{l}\text { Ae. albopictus } \\
\text { MF148292.1 }\end{array}$ & $100 \%$ & $614 \mathrm{pb}$ \\
\hline Ae. scapularis & $\begin{array}{l}\text { Aedes (och) } \\
\text { scapularis } \\
\text { MF172267.1 }\end{array}$ & $98 \%$ & $643 \mathrm{pb}$ \\
\hline Cx. declarator & $\begin{array}{l}\text { Cx. declarator } \\
\text { NC037822.1 }\end{array}$ & $99 \%$ & $474 \mathrm{pb}$ \\
\hline Cx. dolosus & $\begin{array}{l}\text { Cx. dolosus } \\
\text { KF919216.1 }\end{array}$ & $99 \%$ & $646 \mathrm{pb}$ \\
\hline Cx. quinquefasciatus & $\begin{array}{l}\text { Cx. quinquefasciatus } \\
\text { GU188856.2 }\end{array}$ & $99 \%$ & $411 \mathrm{pb}$ \\
\hline$C x$. grupo Coronator & $\begin{array}{l}\text { CX. }(C x .) \text { coronator } \\
\text { KX671399.1 }\end{array}$ & $99 \%$ & $517 \mathrm{pb}$ \\
\hline$T x . s p$ & $\begin{array}{l}\text { Tx. sp } \\
\text { MF577258.1 }\end{array}$ & $99 \%$ & $579 \mathrm{pb}$ \\
\hline Ma. titillans & $\begin{array}{l}\text { Wyeomya } \\
\text { (Decamyia) } \\
\text { ulocoma (Theobald, } \\
\text { 1903) } \\
\text { KF671040.1 } \\
\text { Culicidae sp } \\
\text { KY117374.1 }\end{array}$ & $90 \%$ & $512 \mathrm{pb}$ \\
\hline
\end{tabular}

A espécie Ma. titillans foi destacada em negrito, pois apresentou baixa taxa de similaridade com as espécies mais próximas alinhadas e descritas pelo GenBank®: Wy. ulocoma (90\%) e Culicidae sp. (90\%). 
Tabela 8- Descrição das porcentagens de similaridade das sequências das espécies de mosquitos do Parque Santo Dias, do Município de São Paulo, obtidas em novembro de 2018:

\begin{tabular}{|c|c|c|c|}
\hline Espécime & $\begin{array}{l}\text { Espécie e número do } \\
\text { GenBank } \AA\end{array}$ & $\%$ similaridade & $\begin{array}{c}\text { Tamanho do } \\
\text { fragmento }\end{array}$ \\
\hline Ae. albopictus & $\begin{array}{l}\text { Ae. albopictus } \\
\text { MG913592.1 }\end{array}$ & $100 \%$ & $384 \mathrm{pb}$ \\
\hline Cx.chidesteri & $\begin{array}{l}\text { Cx. chidesteri } \\
\text { KF919243.1 }\end{array}$ & $99 \%$ & $503 \mathrm{pb}$ \\
\hline Cx. declarator & $\begin{array}{l}\text { Culex (Culex) bidens } \\
\text { Dyar, } 1922 \\
\text { KY581239.1 } \\
\text { Cx. declarator } \\
\text { NC037822.1 }\end{array}$ & $100 \%$ & $450 \mathrm{pb}$ \\
\hline Cx. imitator & $\begin{array}{l}\text { Cx. imitator } \\
\text { GU291979.1 }\end{array}$ & $99 \%$ & $610 \mathrm{pb}$ \\
\hline Cx. nigripalpus & $\begin{array}{l}\text { Cx. nigripalpus } \\
\text { KF919228.1 }\end{array}$ & $99 \%$ & $591 \mathrm{pb}$ \\
\hline Li. durhami & $\begin{array}{l}\text { Li. durhami } \\
\text { MF172331.1 }\end{array}$ & $98 \%$ & $535 \mathrm{pb}$ \\
\hline Wyeomyia sp. & $\begin{array}{l}\text { Wyeomyia (Phoniomyia) } \\
\text { splendida Bonne- } \\
\text { Wepster \& Bonne } 1919 \\
\text { MF172504.1 }\end{array}$ & $89 \%$ & $597 \mathrm{pb}$ \\
\hline
\end{tabular}

A espécie Cx. declarator apresentou $100 \%$ de similaridade com a espécie Cx. bidens e, 99\% de similaridade com Cx. declarator. Já a espécie Wy. sp. apresentou $89 \%$ de similaridade com Wy. splendida, a espécie mais próxima selecionada pelo GenBank®. As duas foram destacadas em negrito na tabela acima. 
Tabela 9- Descrição das porcentagens de similaridade das sequências das espécies de mosquitos do Parque Shangrilá, do Município de São Paulo, obtidas em novembro de 2018:

\begin{tabular}{|c|c|c|c|}
\hline Espécime & $\begin{array}{c}\text { Espécie e número } \\
\text { do GenBank }{ }^{\circledR}\end{array}$ & $\%$ similaridade & $\begin{array}{c}\text { Tamanho do } \\
\text { fragmento }\end{array}$ \\
\hline An. fluviatilis & $\begin{array}{l}\text { Ochlerotatus fluviatilis } \\
\text { KF314738.1 }\end{array}$ & $99 \%$ & $409 \mathrm{pb}$ \\
\hline Cx. chidesteri & $\begin{array}{l}\text { Cx. chidesteri } \\
\text { KF919253.1 }\end{array}$ & $99 \%$ & $508 \mathrm{pb}$ \\
\hline Cx. (Mel.) ribeirensis & $\begin{array}{l}\text { Cx. (Melanoconion) } \\
\text { crybda (Dyar, 1924) } \\
\text { KX779884.1 } \\
\text { Cx. (Mel) ribeirensis } \\
\text { Kx779863.1 }\end{array}$ & $95 \%$ & $542 \mathrm{pb}$ \\
\hline Li. durhami & $\begin{array}{l}\text { Li. durhami } \\
\text { Mf172331 }\end{array}$ & $96 \%$ & $448 \mathrm{pb}$ \\
\hline Ma. wilsoni & $\begin{array}{l}\text { Ma. titillans } \\
\text { KY859902.1 }\end{array}$ & $93 \%$ & $353 \mathrm{pb}$ \\
\hline Tx. sp. & Tx.Sp. & $98 \%$ & $646 \mathrm{pb}$ \\
\hline
\end{tabular}

$\mathrm{Na}$ Tabela 9, seguindo o padrão das tabelas anteriores, a espécie Cx. (Mel.) ribeirensis apresentou baixa taxa de similaridade com Cx. crybda e com Cx. ribeirensis. A espécie Ma. wilsoni, apresentou baixa taxa de similaridade com Ma. titillans. As duas espécies também foram destacadas em negrito para essas características.

\subsection{ALINHAMENTOS}

A maioria das espécies não teve nenhuma divergência significativa nos alinhamentos com as espécies do GenBank®. O que ilustra a Figura 12. A seguir, nas Figuras 13 e 14 estão ilustrados os alinhamentos de algumas 
espécies onde apareceram divergências ou situações relevantes. Algumas

figuras ilustram a pesquisa no GenBank® e os respectivos números de acesso.

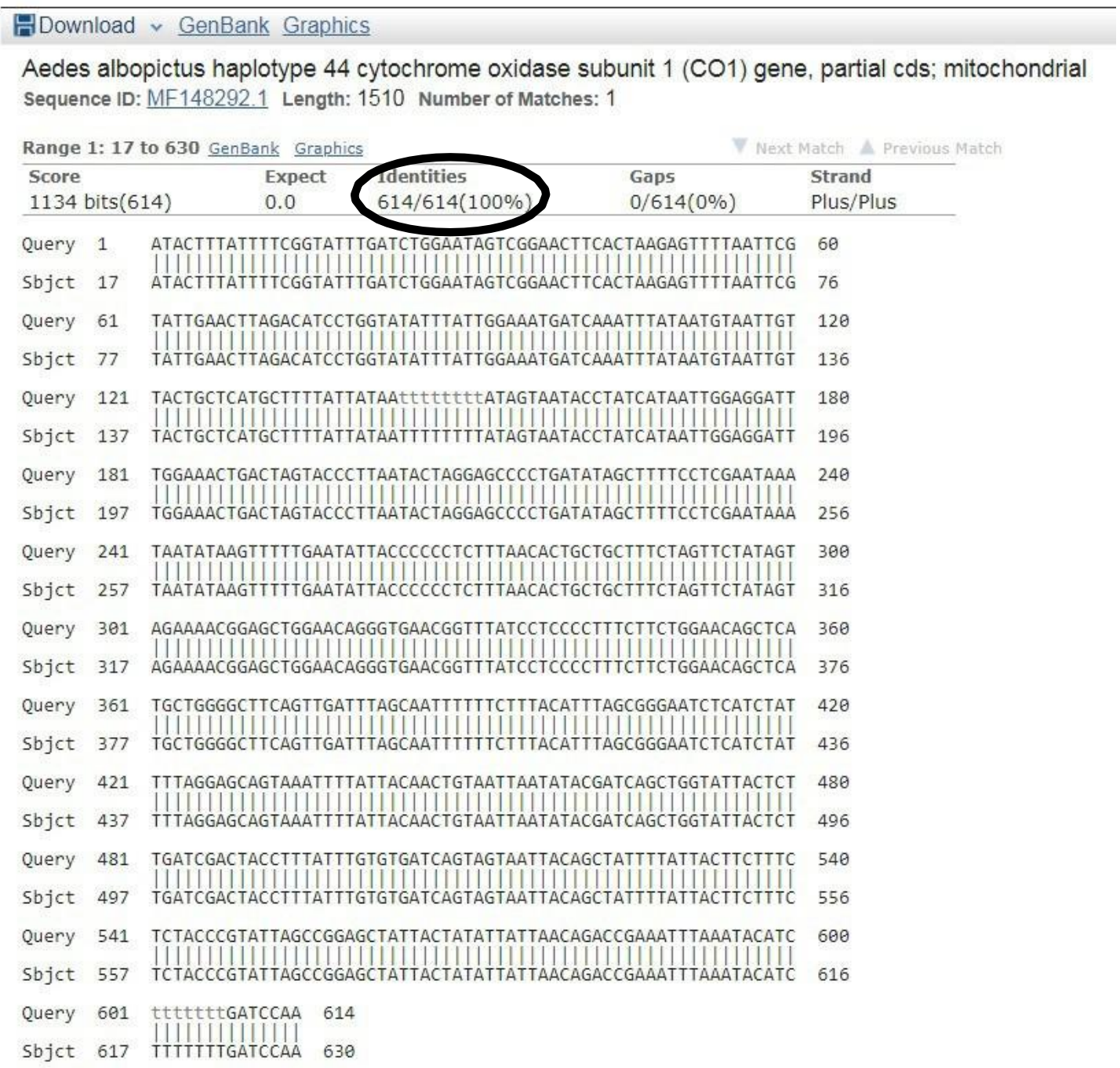

Figura 12- Alinhamento original da espécie Ae. albopictus do parque Ibirapuera com a sequência do GenBank ${ }^{\circledR}$. Com $100 \%$ de similaridade. A sequência de interesse é a da parte superior do alinhamento. 
Wyeomyia sp. stB voucher ST10121 cytochrome oxidase subunit 1 (COI) gene, partial cds; mitochondrial Sequence ID: MF172505.1 Length: 658 Number of Matches: 1

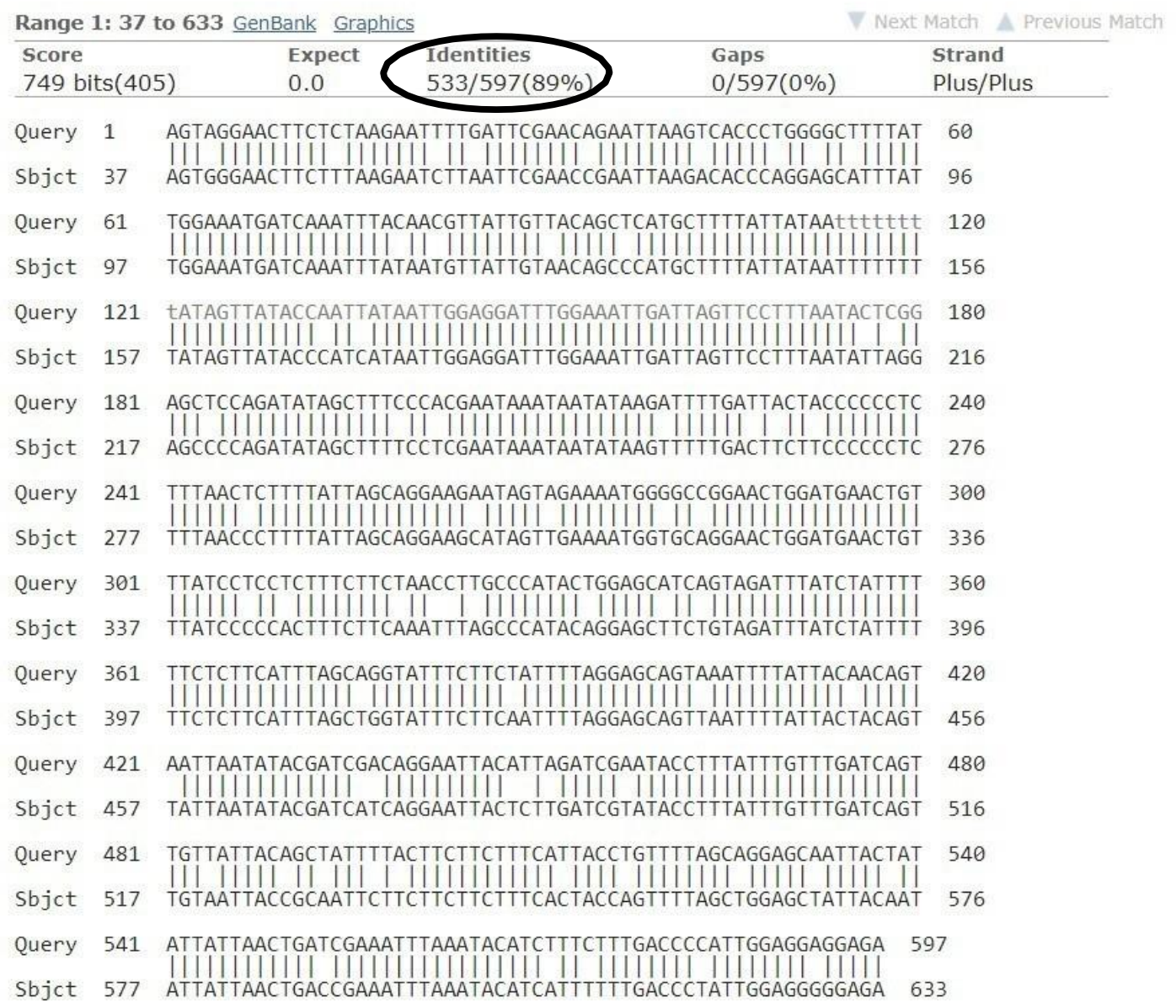

Figura 13- Alinhamento original da espécie Wy. sp. do Parque Santo Dias, com a mais próxima Wy. $s p$. do GenBank®, mostrando o valor de $89 \%$ de similaridade entre as duas espécies. A sequência de interesse se encontra na parte superior do alinhamento. 


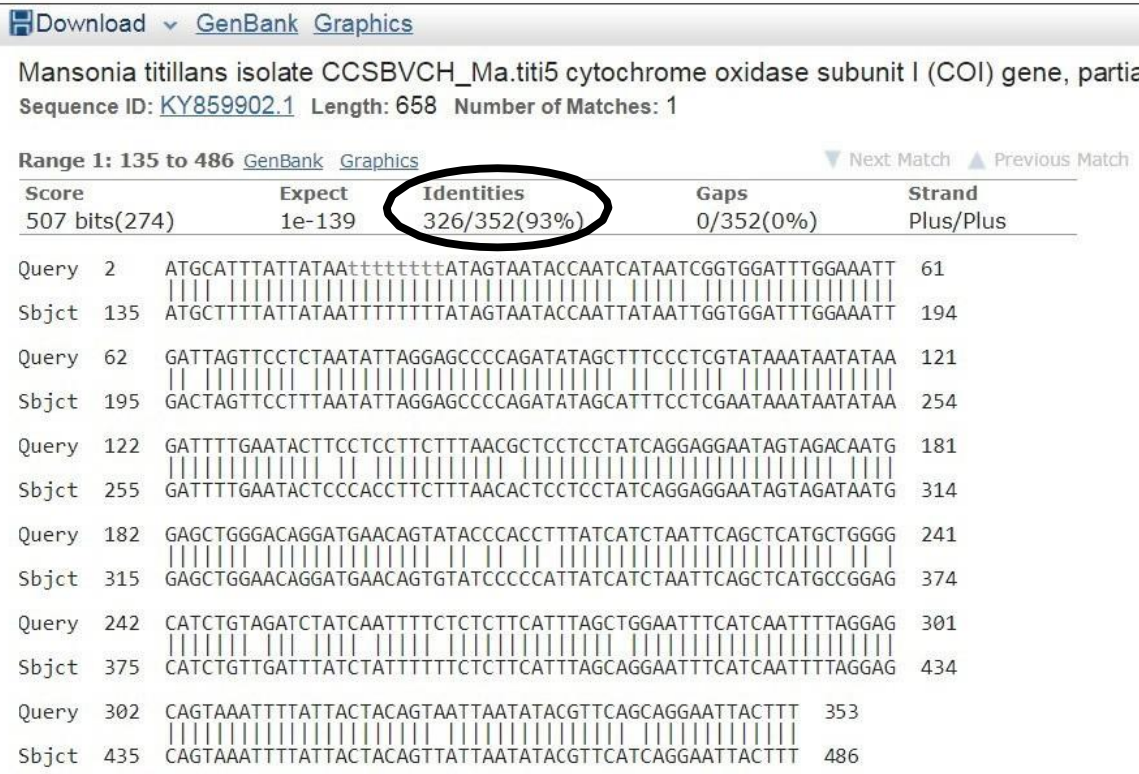

Figura 14- Alinhamento original da espécie Ma. wilsoni do parque Shangrilá, com Ma. titillans do GenBank ${ }^{\circledR}$, mostrando o valor de $93 \%$ de similaridade entre elas. A sequência de interesse fica na parte superior do alinhamento.

Sequences producing significant alignments:

Select: All None Selected:0

\begin{tabular}{|c|c|c|c|c|c|c|c|}
\hline \multicolumn{8}{|c|}{ 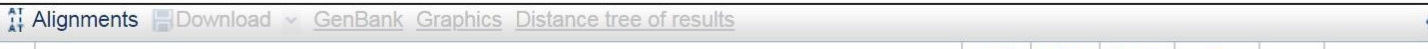 } \\
\hline & Description & $\begin{array}{l}\text { Max } \\
\text { score }\end{array}$ & $\begin{array}{l}\text { Total } \\
\text { score }\end{array}$ & $\begin{array}{l}\text { Query } \\
\text { cover }\end{array}$ & $\begin{array}{c}E \\
\text { value }\end{array}$ & & Accession \\
\hline$\square$ & Wyeomyia ulocoma voucher CCDB-10763-H07 cytochrome oxidase subunit 1 (COl).gene, partial cds; mitochs & 660 & 660 & $99 \%$ & 0.0 & & \\
\hline$\square$ & Wyeomyia ulocoma voucher CCDB-10764-A05 cytochrome oxidase subunit 1 (COI)-gene, partial co & 654 & 654 & $99 \%$ & 0. & & 39.1 \\
\hline$\square$ & Wyeomyia ulocoma voucher CCDB-10764-C02 cytochrome oxidase subunit 1 (COl),gene, partial cds; mitochs & 654 & 654 & $99 \%$ & 0.0 & & 1 \\
\hline$\square$ & Culicidae sp. JPS017_Wy cytochrome oxidase subunit I (COI) gene, partial cds; mitochondrial & 649 & 649 & $99 \%$ & 0.0 & & 4.1 \\
\hline$\square$ & Culicidae sp. JBB31-1_Wy cytochrome oxidase subunit I ( $\mathrm{COI}$ )gene, partial cds; mitochondrial & 649 & 649 & $99 \%$ & 0.0 & & $\underline{\mathrm{KY} 117371.1}$ \\
\hline$\square$ & Wyeomyia ulocoma voucher CCDB-10764-A03 cytochrome oxidase subunit 1 (COI)_gene, partial cds; mitochc & 649 & 649 & $99 \%$ & 0.0 & $90 \%$ & KF671044.1 \\
\hline$\square$ & Aedes vexans voucher NEONTculicid791 cytochrome oxidase subunit 1 (COI) gene, partial cds; mitochondrial & 1) 643 & 643 & $99 \%$ & $1 e-180$ & $89 \%$ & $\underline{\mathrm{J} \times 259703.1}$ \\
\hline$\square$ & Aedes vexans voucher BIOUG<CAN>:10BBCDIP-2311 cytochrome oxidase subunit 1 (COI),gene, partial cds; & ; 643 & 643 & $99 \%$ & $1 e-180$ & $89 \%$ & $\underline{\mathrm{J} F 868958.1}$ \\
\hline$\square$ & Culicidae sp. ANT79-131_Wy cytochrome oxidase subunit I (COI) gene, partial cds; mitochondrial & 641 & 641 & $99 \%$ & $5 e-180$ & $89 \%$ & $\underline{\mathrm{KY} 117373.1}$ \\
\hline$\square$ & Culicidae sp. 5JBr2-3_Wy cytochrome oxidase subunit I ( $\mathrm{COI}$ ) gene, partial cds; mitochondrial & 641 & 641 & $99 \%$ & $5 e-180$ & $89 \%$ & $\underline{\text { KY117368.1 }}$ \\
\hline$\square$ & Aedes sp. BOLD:AAA7067 voucher BIOUG08857-G01 cytochrome oxidase subunit 1 (COI) gene, partial cds; & 641 & 641 & $98 \%$ & $5 e-180$ & $90 \%$ & KM907905.1 \\
\hline$\square$ & Aedes vexans cytochrome oxidase subunit I ( $\mathrm{COI}$ ).gene, partial cds; mitochondrial & 638 & 638 & $99 \%$ & $6 e-179$ & $89 \%$ & MG242525.1 \\
\hline$\square$ & Aedes vexans voucher BIOUG01574-F08 cytochrome oxidase subunit 1 (COI) gene, partia & 38 & 638 & $99 \%$ & $6 e-179$ & $89 \%$ & 309.1 \\
\hline
\end{tabular}

Figura 15- Resultado da pesquisa no GenBank® dos alinhamentos da espécie Ma. titillans do parque lbirapuera, com as respectivas porcentagens de similaridade das espécies mais próximas e seus números de acesso. 
Sequences producing significantalignments:

Select: All None Selected:0

\begin{tabular}{|c|c|c|c|c|c|c|c|}
\hline \multicolumn{8}{|c|}{ i: Alignments 1 Download GenBank Graphics Distance tree of results } \\
\hline & Description & $\begin{array}{l}\text { Max } \\
\text { score }\end{array}$ & $\begin{array}{l}\text { Total } \\
\text { score }\end{array}$ & $\begin{array}{l}\text { Query } \\
\text { cover }\end{array}$ & $\begin{array}{c}E \\
\text { value }\end{array}$ & Ident & Accession \\
\hline$\square$ & Culex bidens isolate $C_{x}$ bidens_LR_15_24 cytochrome axidase subunit I (COligene, partial cds; mitachondrie & 876 & 876 & $100 \%$ & & & KY581239.1 \\
\hline$\square$ & Culex bidens isolate Cx_bidens_LR_1E_06 cytochrome oxidase subunit_(CO),gene, partial cds; mitochendris & 876 & 876 & $100 \%$ & 0.0 & & KY581238.1 \\
\hline$\square$ & Culex bidens isolate CX_bidens_LR_15_02 eytochrome oxidase subunit I (COl) gene, partial cds; mitechondria & 876 & 876 & $100 \%$ & 0.0 & $100 \%$ & $\underline{K} 581237.1$ \\
\hline$\square$ & Culex bideng isolate Cx_bidens_Cba_15_39 cytochrome oxidase subunit I ( $\mathrm{CO}$ ),gene, partial cds; mitochondr & 876 & 876 & $100 \%$ & 0.0 & $100 \%$ & KY581220.1 \\
\hline$\square$ & Culex bidens isolate $\mathrm{Cx}$ bidens_Cba_15_32 cytochrome oxidase subunit $\mathrm{I}$ ( $\mathrm{CO}$ ).gene, partial eds; mitochondr & 876 & 876 & $100 \%$ & 0.0 & $100 \%$ & KY581219.1 \\
\hline$\square$ & Culex bidens isolate $\mathrm{Cx}$ _bidens_Cba_15_15 cytochrome cxidase subunit I ( & 876 & 876 & $100 \%$ & 0.0 & $100 \%$ & KY581216.1 \\
\hline$\square$ & Culex bidens isolate Cx_bidens_Cba_15_07 cytochrome oxidase subunit $\perp$ (CO) & 876 & 876 & $100 \%$ & 0.0 & $100 \%$ & KY581213.1 \\
\hline$\square$ & 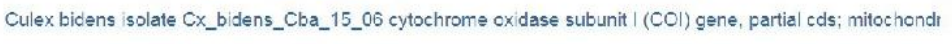 & 876 & 876 & $100 \%$ & 0.0 & $100 \%$ & $\underline{K Y 581212.1}$ \\
\hline$\square$ & Culex bidens isolate $\mathrm{Cx}$ bidens_Cat_12_57 cytochrome oxidase subunit I (COal) gene, partial cds: mitochondri & 876 & 876 & $100 \%$ & 0.0 & $100 \%$ & KYE81209.1 \\
\hline$\square$ & Culex bidens voucher M108 cytochrome c oxidase subunit I (COligene, partial cds; mitochondrial & 876 & 876 & $100 \%$ & 0.0 & $100 \%$ & KF919201.1 \\
\hline$\square$ & Culex declarator clone SP36_100 mitochondrion, complete geneme & 870 & 870 & $100 \%$ & 0.0 & & \\
\hline
\end{tabular}

Figura 16- Resultado da pesquisa no GenBank ${ }^{\circledR}$ dos alinhamentos da espécie $C x$. declarator do parque Ibirapuera, mostrando $100 \%$ de similaridade com a espécie Cx. bidens e $99 \%$ de similaridade com $C x$. declarator.

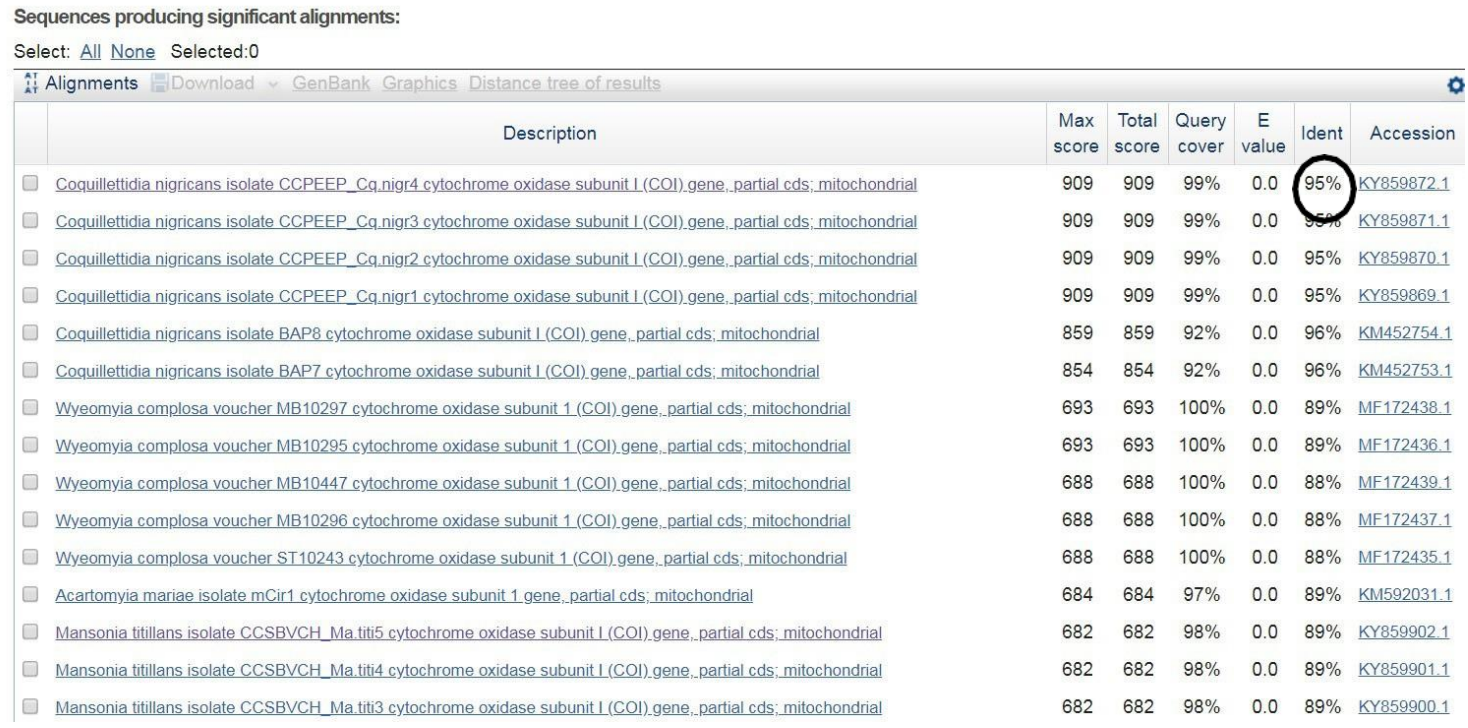

Figura 17- Resultado da pesquisa no GenBank® dos alinhamentos da espécie Cq. venezuelensis, mostrando 95\% de similaridade com vários espécimes de Cq. nigricans. 


\section{7. ÁRVORES FILOGENÉTICAS}

A seguir as Figuras das árvores filogenéticas produzidas após o alinhamento das espécies por parque e árvore única com todos os parques.

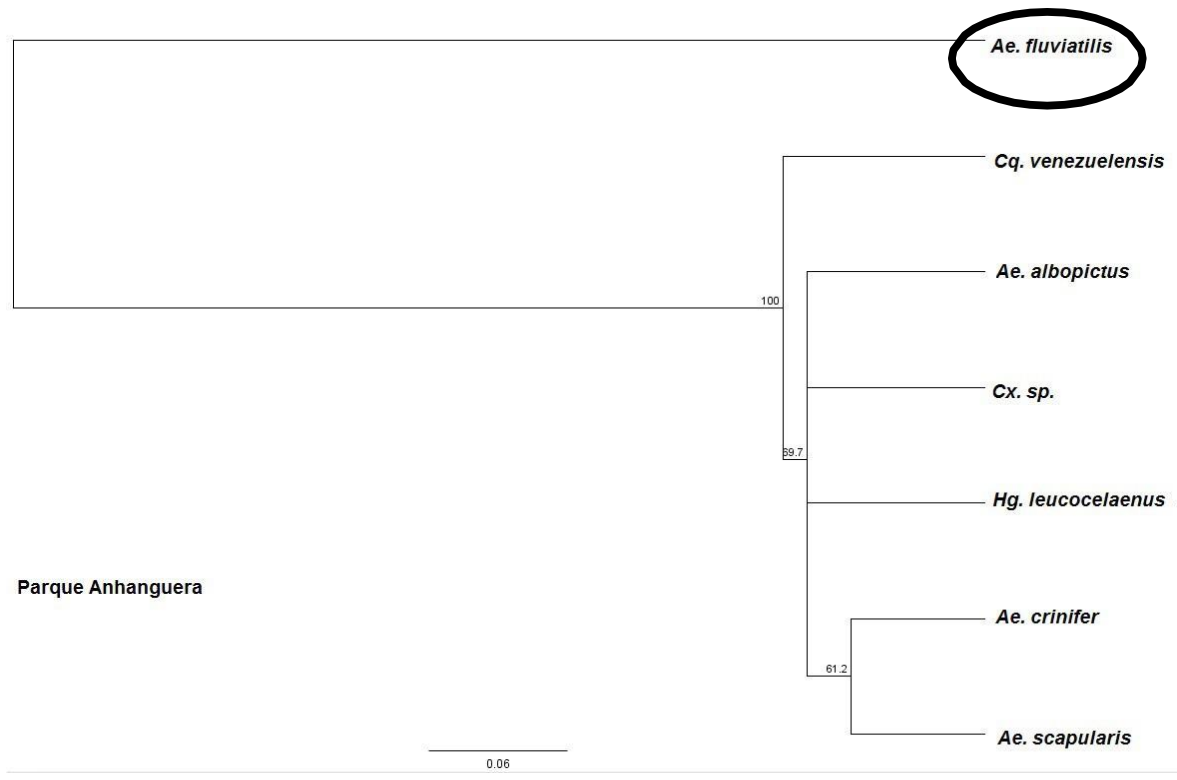

Figura 18- Parque Anhanguera (HKY- UPGMA), mostrando o Ae. fluviatilis como grupo externo, o que significa que é o mais primitivo

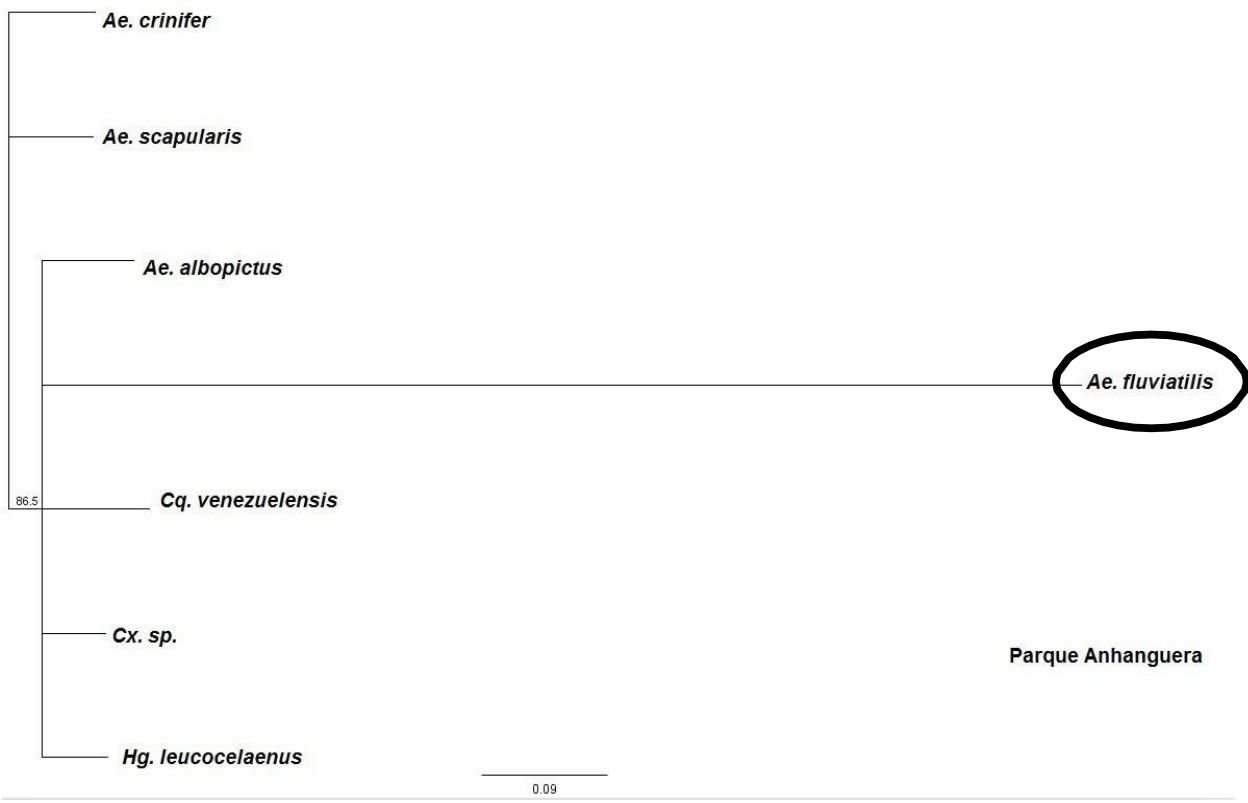

Figura 19- Parque Anhanguera (HKY- Neighbor-joining). Confirma o Ae. fluviatilis como grupo externo, confirmando a árvore da figura 18 


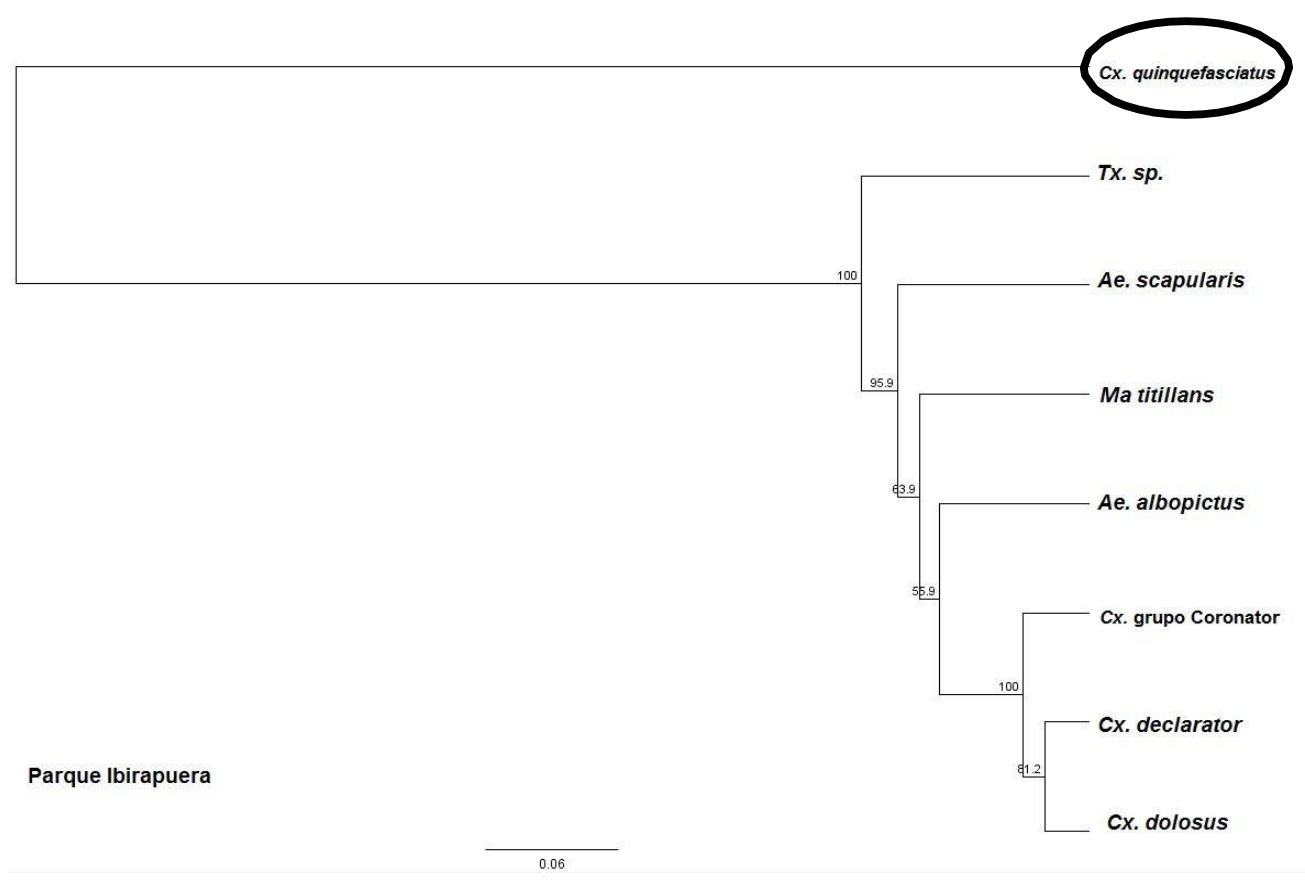

Figura 20- Parque Ibirapuera (HKY- UPGMA). Em destaque a espécie $C x$. quinquefasciatus que aparece como grupo mais antigo em relação aos demais.

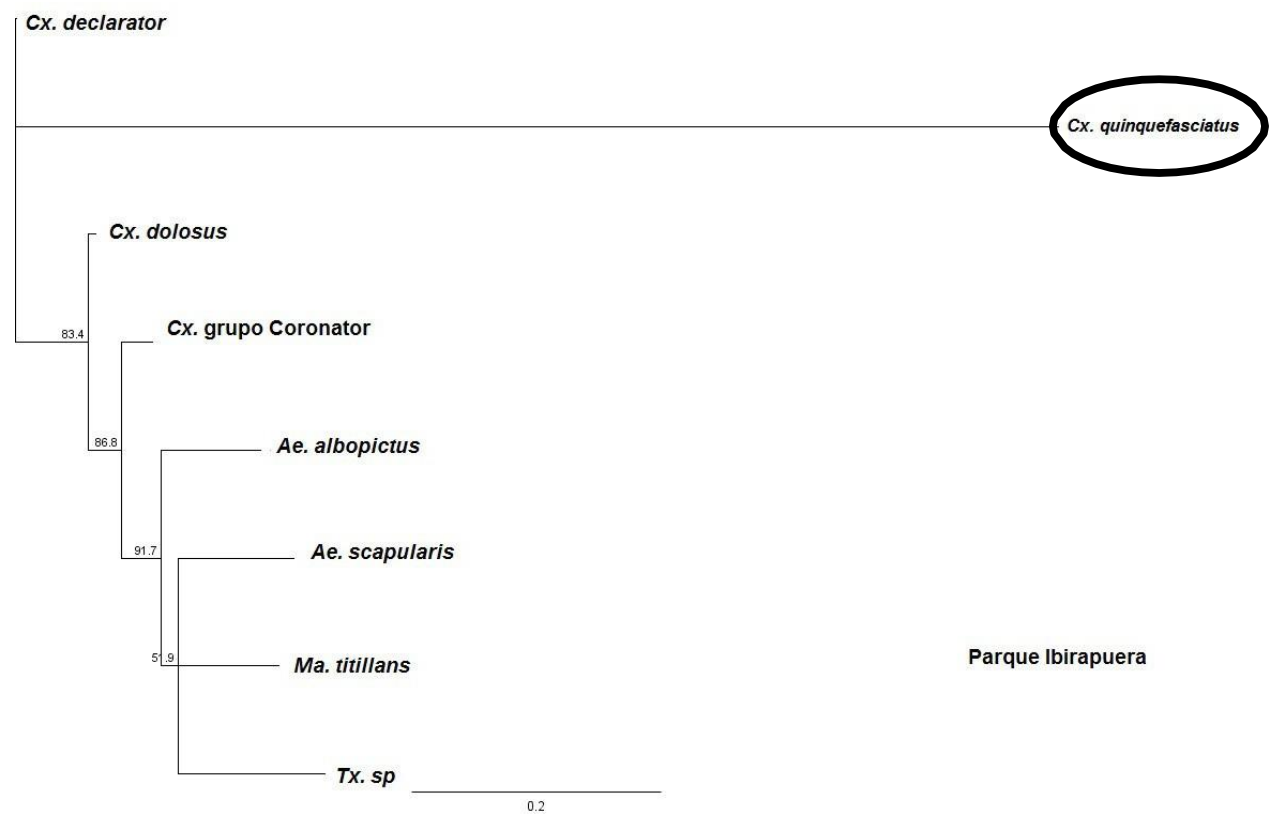

Figura 21- Parque Ibirapuera (HKY- Neighbor-joining). Confirma o Cx. quinquefasciatus como ancestral comum de todas as demais espécies. 


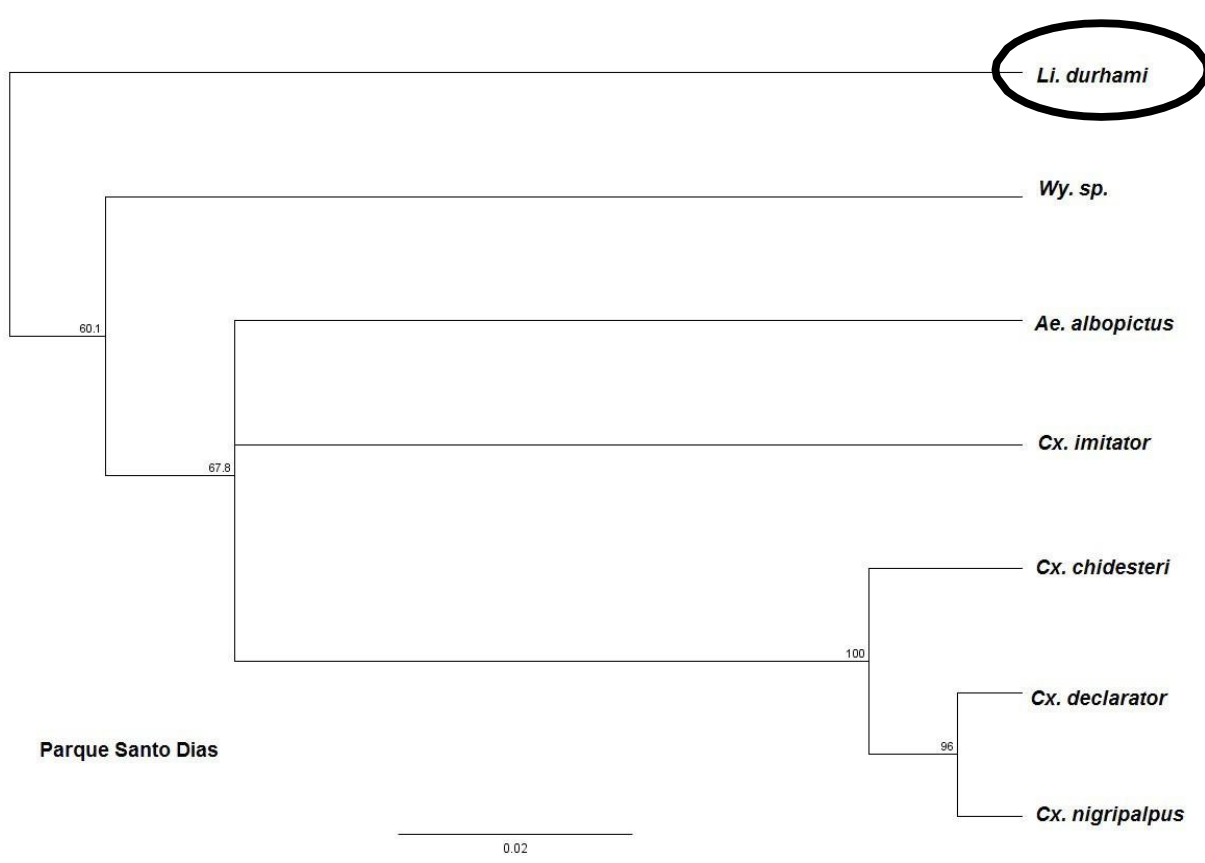

Figura 22- Parque Santo Dias (HKY- UPGMA). Mostra o Li. durhami como grupo externo (mais primitivo)

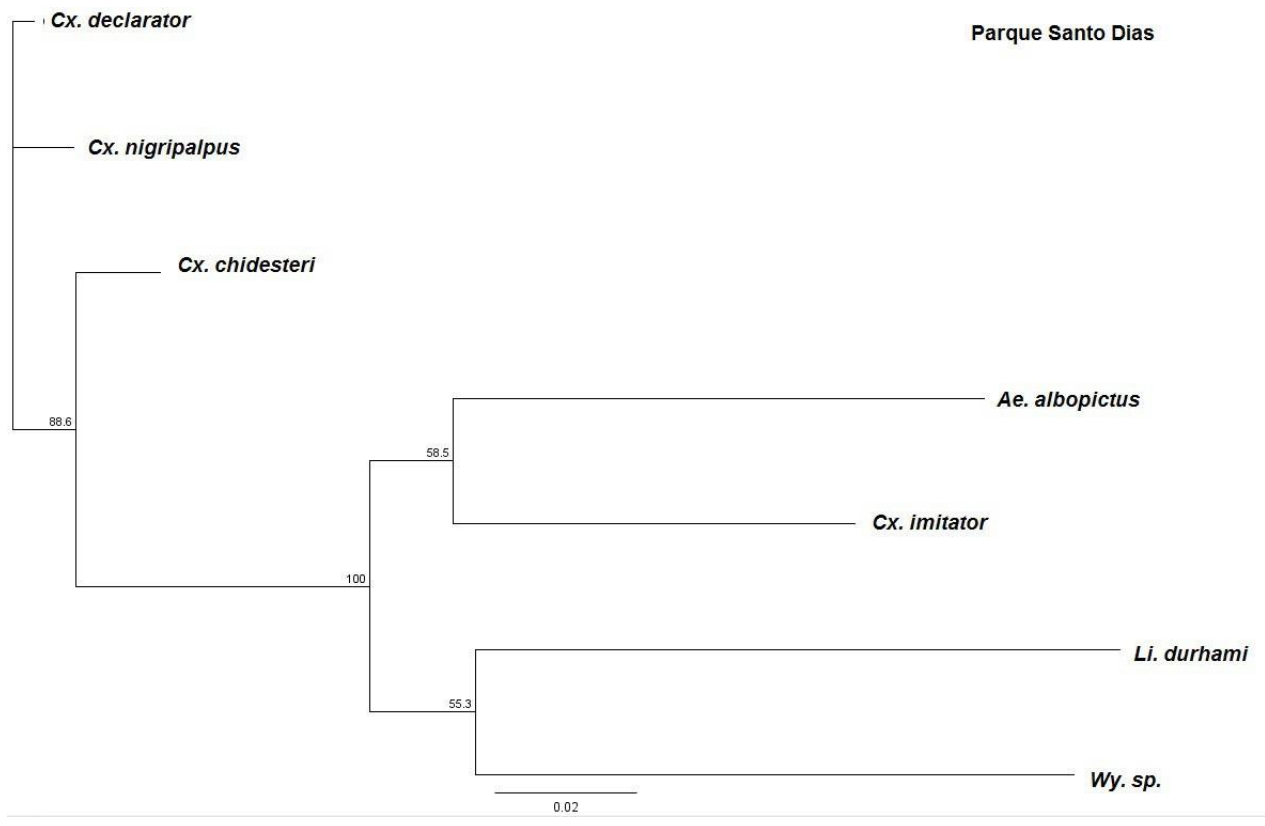

Figura 23- Parque Santo Dias (HKY-Neighbor-joining). A espécie $C x$. declarator aparece como a mais primitiva, junto com a espécie $C x$. nigripalpus. 
Li. durhami

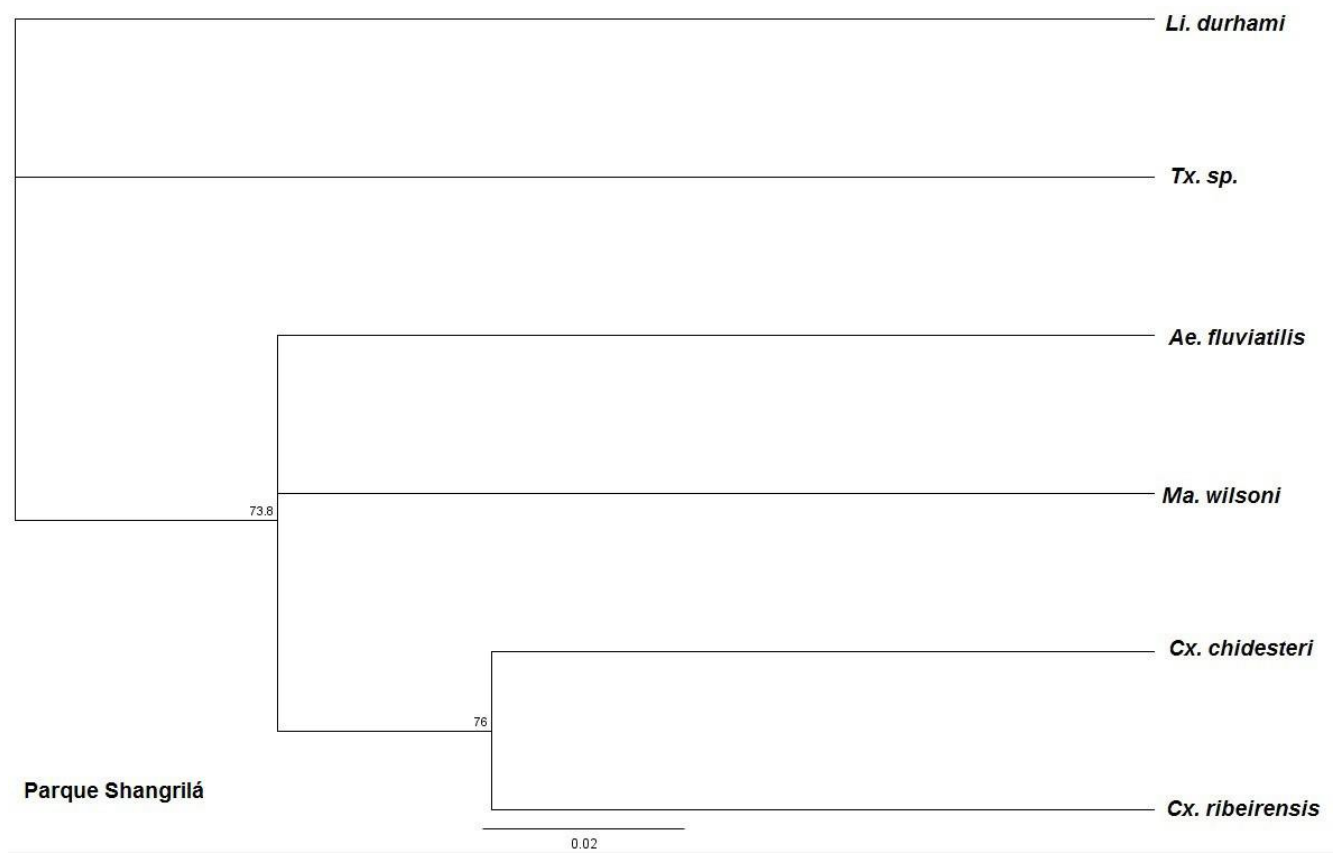

Figura 24- Parque Shangrilá (HKY- UPGMA). Cx. chidesteri e Cx. ribeirensis aparecem no mesmo cluster

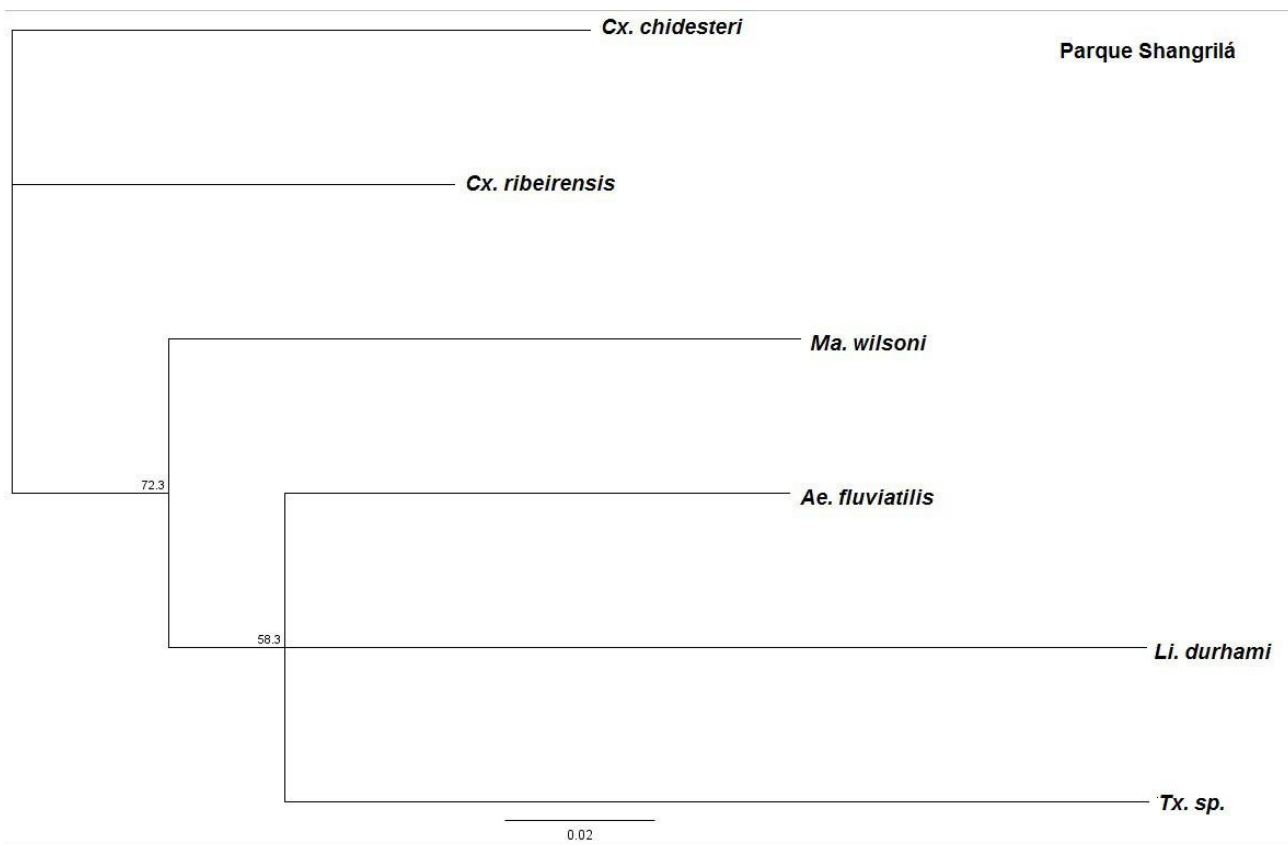

Figura 25- Parque Shangrilá (HKY- Neighbor-joining). Cx. chidesteri e Cx. ribeirensis muito próximos e externos ao grupo 


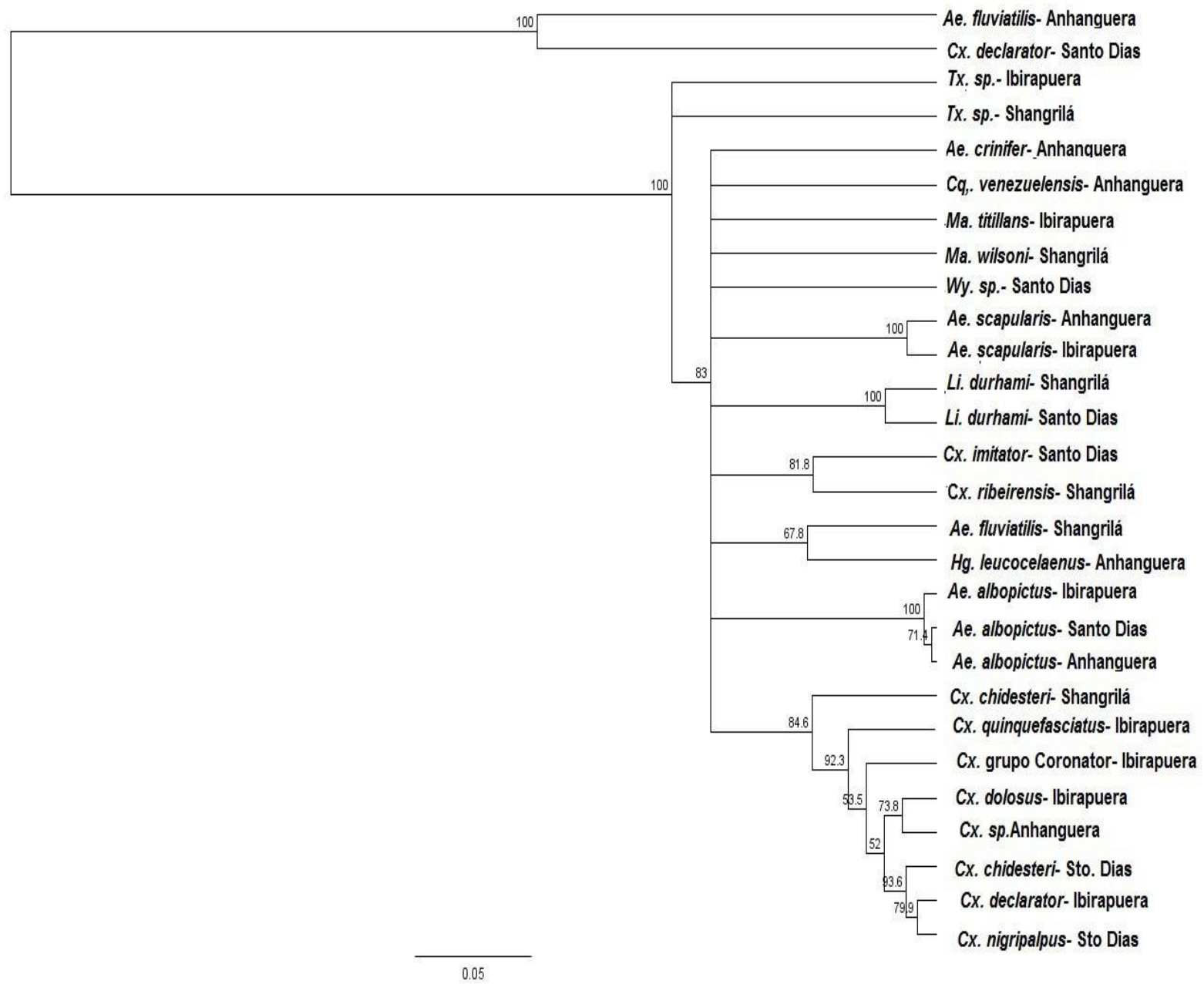

Figura 26- Árvore UPGMA mostrando todos os 28 espécimes do estudo que foram sequenciados. A espécie Ae. fluviatilis do parque Anhanguera e a espécie $\boldsymbol{C x}$. declarator do parque Santo Dias aparecem como os grupos mais antigos em relação aos demais; Os espécimes de Ae. scapularis dos parques Anhanguera e lbirapuera aparecem juntos no mesmo cluster, confirmando a origem dos mesmos; os espécimes de Ae. albopictus dos parques Ibirapuera, Santo dias e Anhanguera, também ficaram juntos no mesmo cluster, confirmando a mesma origem. 
Ae. fluviatilis- Anhanguera

Cx. declarator-Santo Dias

Ae. fluviatilis- Shangrilá

Cq. venezuelensis- Anhanguera

Cx. dolosus- Ibirapuera

Cx. quinquefasciatus- Ibirapuera

CX. sp. Anhanguera

Cx. grupo Coronator- Ibirapuera

Hg. leucocelaenus- Anhanguera

Ma. titillans- Ibirapuera

Ma. wilsoni- Shangrilá

Wy. sp.- Santo Dias

Li. durhami- Shangrilá

Li. durhami- Santo Dias

Cx. imitator-Santo Dias

Cx. ribeirensis- Shangrilá

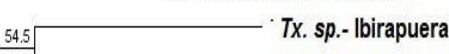

TX. sp.- Shangrilá

Ae. albopictus- Santo Dias

54.t- Ae. albopictus- Anhanguera

- Ae. albopictus- Ibirapuera

Ae. crinifer-Anhanguera

${ }_{100}$ Ae. scapularis- Anhanguera

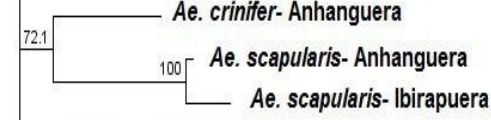

- Cx. declarator- Ibirapuera

Cx. nigripalpus- Santo Dias

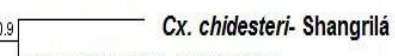

Cx. chidesteri- Santo Dias

Figura 27- Árvore Neighbor-joining para todas as espécies trabalhadas nos quatro parques, confirma a topologia da árvore UPGMA, para a maioria das espécies. 


\subsection{PAISAGEM DOS PARQUES}

A seguir são mostrados os resultados da descrição da paisagem dos quatro parques de interesse: Anhanguera, Ibirapuera, Santo Dias e Shangrilá, no que tange à localização na cidade de São Paulo, fauna, flora e a ligação das espécies de mosquitos estudadas com os ambientes sinantrópicos.

$\mathrm{Na}$ Tabela 10, estão dispostas as áreas vegetais dos parques em hectares e distâncias euclidianas entre eles. Isso mostra que, o Anhanguera é o parque mais distante e com menos conexão com os outros parques.

Tabela 10- Descrição das áreas com cobertura vegetal de cada parque e distância euclidiana entre os parques.

\begin{tabular}{|l|l|l|l|l|}
\hline & $\begin{array}{l}\text { P. Anhanguera } \\
\text { 2413 hectares }\end{array}$ & $\begin{array}{l}\text { P. Santo Dias } \\
\text { 24,5 hectares }\end{array}$ & $\begin{array}{l}\text { P. Ibirapuera } \\
\text { 69 hectares }\end{array}$ & $\begin{array}{l}\text { P. Shangrilá } \\
\mathbf{5 5 4} \text { hectares }\end{array}$ \\
\cline { 2 - 5 } P. Anhanguera & - & $27 \mathrm{~km}$ & $22,8 \mathrm{~km}$ & $39,8 \mathrm{~km}$ \\
\hline P. Santo Dias & $27 \mathrm{~km}$ & - & $14,2 \mathrm{~km}$ & $15,5 \mathrm{~km}$ \\
\hline P. Ibirapuera & $22,8 \mathrm{~km}$ & $14,2 \mathrm{~km}$ & - & $19,4 \mathrm{~km}$ \\
\hline P. Shangrilá & $39,8 \mathrm{~km}$ & $15,5 \mathrm{~km}$ & $19,4 \mathrm{~km}$ & - \\
\hline
\end{tabular}




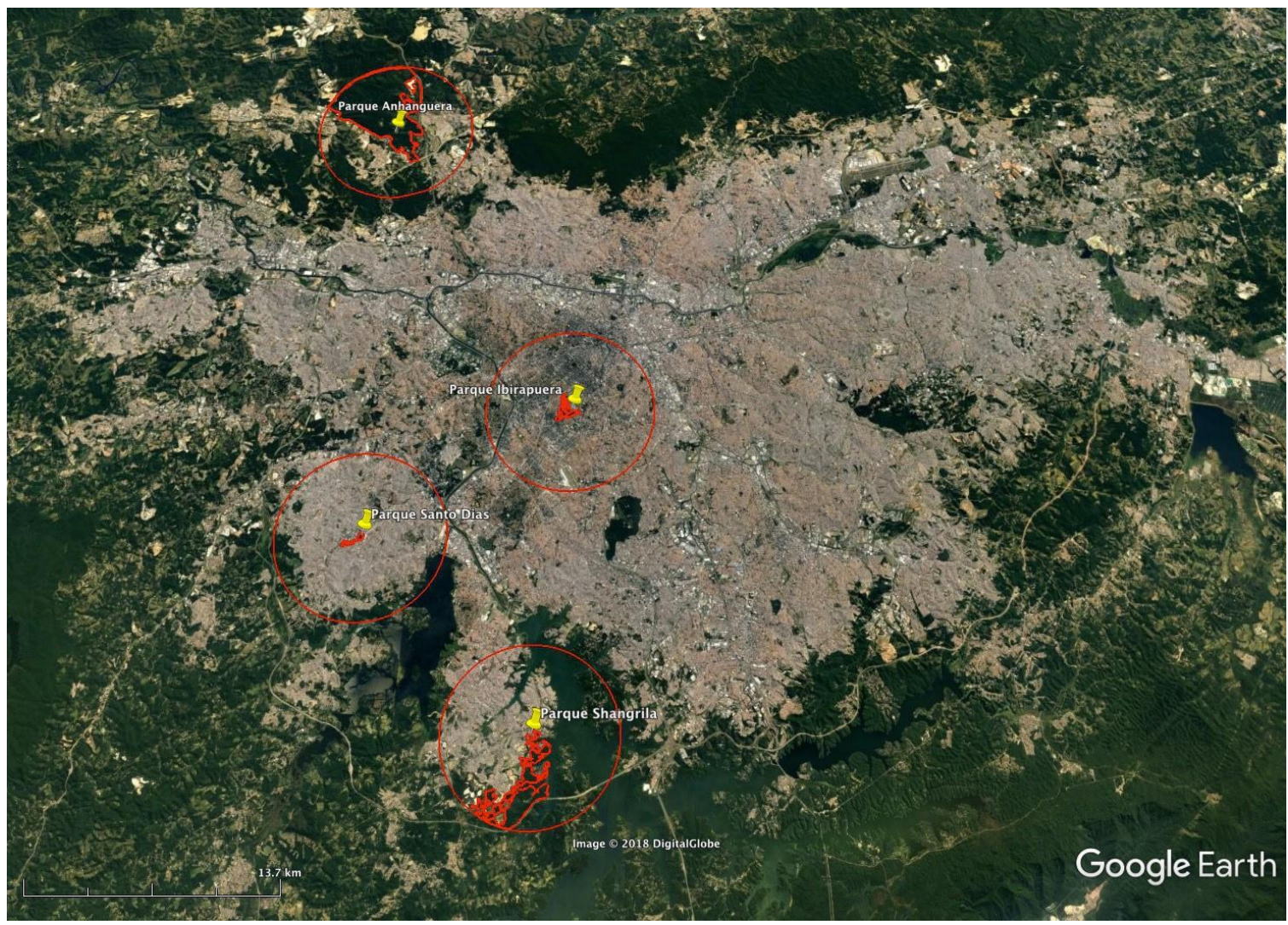

Figura 28- Localização dos parques na cidade de São Paulo. O contorno em vermelho é a área de abrangência e o entorno de cada parque. Fonte: Google Earth

Em relação ao parque Anhanguera, o mais próximo é o parque Ibirapuera, com espécimes de Ae. scapularis, sendo que o do parque Anhanguera apresentou $98 \%$ de similaridade com sequência do banco de genes. Já o exemplar do lbirapuera apresentou $100 \%$ de similaridade. Essa espécie está presente em todo o Brasil e essa diferença confirma a presença de características genéticas de populações locais, o que pode ser observado na Figura 27 (Árvore Neighbor-joining), onde o exemplar do Ibirapuera aparece como um espécime mais antigo, e consequentemente mais sujeito a variações no DNA (o que justifica a variação na sequência do DNA barcoding em 2\%). 


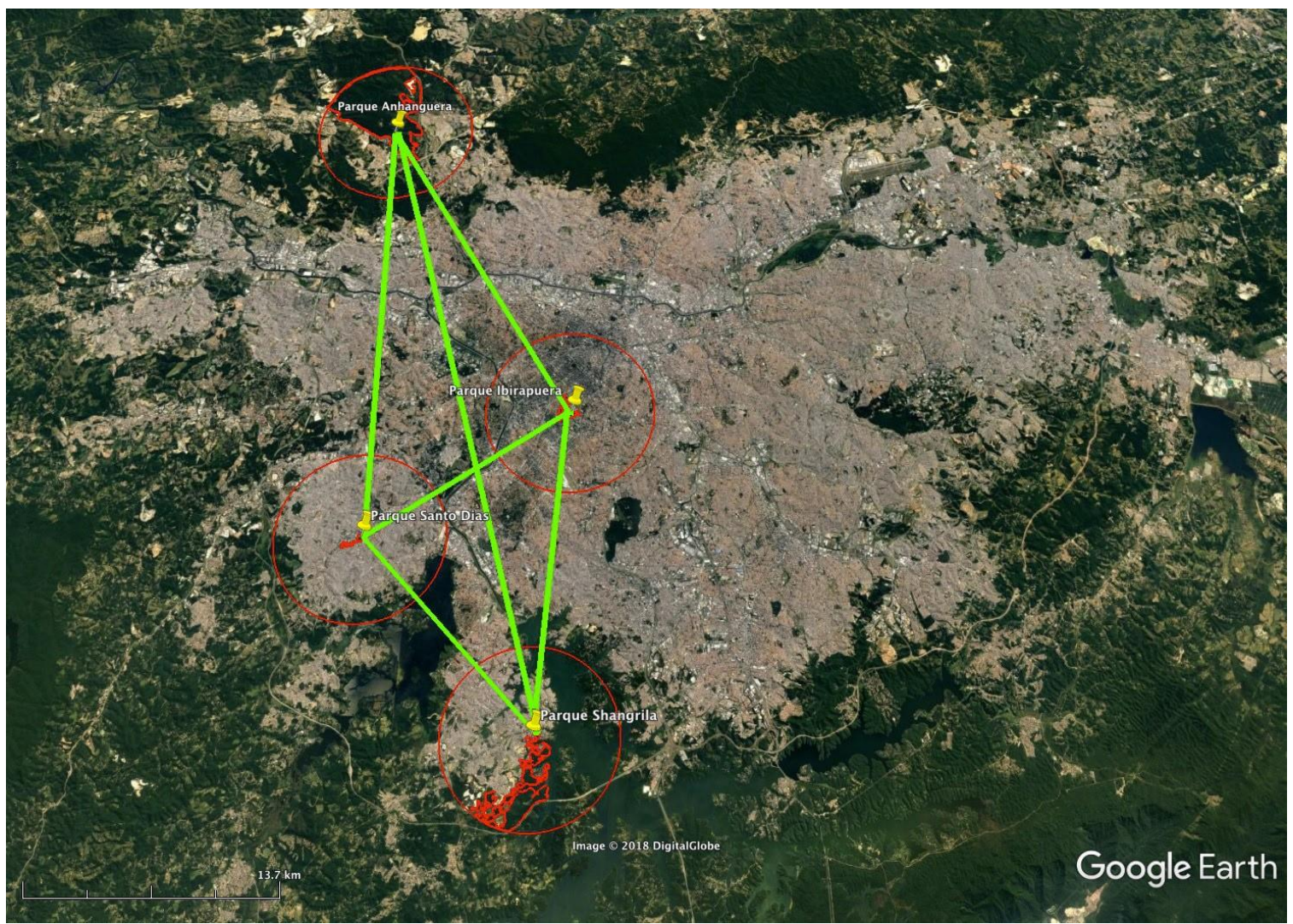

Figura 29- Localização e contorno dos parques do estudo na cidade de São Paulo (em vermelho), com os respectivos nomes e entorno; em verde as distâncias euclidianas entre os parques. Fonte: Google Earth

Os parques Ibirapuera e Santo Dias, os mais próximos entre si, de acordo com a Figura 29, apresentaram uma espécie em comum: $C x$. declarator. Os dois exemplares sequenciados apresentaram a mesma porcentagem de similaridade (99\%), inclusive com um exemplar brasileiro já registrado no banco de genes. Isso levanta claramente a hipótese de uma conexão, em tempos remotos, entre os dois parques (corredores de ligação). 


\section{5- DISCUSSÃO}

Durante o período de estudo do projeto Biodiversidade de mosquitos (Diptera:Culicidae) nos parques da cidade de São Paulo", no período entre outubro de 2010 e fevereiro de 2011, foram coletados 5.129 espécimes entre imaturos e adultos. $\mathrm{Na}$ análise das coletas, o parque Anhanguera apresentou a maior riqueza de espécies, o parque Ibirapuera ficou em terceiro lugar e o Shangrilá, em quarto. Em destaque, a espécie Cx. quinquefasciatus (tabela 5), com o maior número de exemplares coletados (MEDEIROS-SOUSA et al, 2013).

Para os estudos epidemiológicos e de saúde pública, o $C x$. quinquefasciatus é importante vetor de parasitoses infecciosas que colocam em risco a população exposta às doenças emergentes e as arboviroses, como 0 vírus Oropouche (vetor secundário no Brasil). Também muito conhecido pelo incômodo e à constante e intensa presença do inseto junto às populações humanas (CONSOLI \& LOURENÇO DE OLIVEIRA, 1994, MORAES, et al, 2006).

O exemplar sequenciado foi 0 do parque lbirapuera e, apresentou a porcentagem de similaridade esperada $(99 \%)$ com $C x$. quinquefasciatus do GenBank®, assim como para a espécie $C x$. pipiens (99\%), cuja denominação ficou por muito tempo conhecido, devido às similaridades morfológicas com as espécies do complexo (CONSOLI \& LOURENÇO DE OLIVEIRA, 1994). Apesar de ser uma das espécies que apresentou maior frequência em 27 parques dos 35 que fizeram parte do estudo de biodiversidade e, presente nos 4 parques desta pesquisa, foi selecionado apenas no parque Ibirapuera por ser um local estratégico devido à frequência das pessoas. Nos estudos anteriores, foi a espécie com maior número de imaturos coletados em recipientes artificiais (MEDEIROS-SOUSA, 2014). Essa informação é relevante, pois confirma a adaptação da espécie ao ambiente sinantrópico.

A árvore filogenética do parque lbirapuera (UPGMA) apresenta 0 $C x$. quinquefasciatus como grupo externo. Consequentemente mais antigo que as demais espécies do parque. Já a árvore Neighbor-joining classifica a espécie em um cluster isolado junto com $C x$. declarator (figuras 20 e 21), mas ainda 
como o mais antigo. Isso indica uma diferenciação anterior às demais do estudo. A hipótese talvez explique a grande capacidade dessa espécie de se alimentar em inúmeros hospedeiros e o alto grau de sinantropia nos ambientes urbanos (TAIPE-LAGOS \& NATAL, 2003).

O Ae. scapularis (tabela 5) foi registrado nos quatro parques. Apresentou 98\% de similaridade com Ae. scapularis do GenBank®, originado da Guiana Francesa, para o parque Ibirapuera. Já para o parque Anhanguera, o exemplar sequenciado mostrou $100 \%$ de similaridade com a mesma espécie, um exemplar do Estado de São Paulo (tabela 6). Os números de acesso das espécies do GenBank® encontram-se nas Tabelas 7 e 8 . É considerada espécie oportunista, alimentando-se do sangue humano, mas prefere mamíferos de grande porte como bovinos e equinos (CONSOLI \& LOURENÇO DE OLIVEIRA, 1994). Considerado capaz de transmitir o vírus do Rocio no Vale do Ribeira (São Paulo) e Dirofilaria immitis (Leidy, 1856), parasita de cães no Rio de janeiro (FORATTINI, 2002).

$\mathrm{Na}$ análise topológica das árvores do parque Anhanguera (Figuras $18 \mathrm{e}$ 19), Ae. scapularis (tabela 5) e Ae. crinifer aparecem como espécies muito próximas na árvore UPGMA (grupo monofilético), já no método Neighbor-joining aparecem relacionadas, mas como grupos externos às demais espécies do parque. Nas análises gerais (figuras 26 e 27), com todos os espécimes de todos os parques, confirma-se a relação entre as duas espécies e as duas árvores confirmam o Ae. crinifer como organismo mais antigo entre as duas. O Ae. scapularis foi relatado como possível vetor de arboviroses (GUIMARÃES et al,1987). O que justifica mais estudos dessa espécie.

O Ae albopictus com $100 \%$ de similaridade com a mesma espécie através dos alinhamentos do GenBank®, foi registrado em 24 parques da cidade de São Paulo (MEDEIROS-SOUSA et al, 2013). E identificado nos quatro parques do estudo, onde foram também sequenciados exemplares dos parques Anhanguera e Santo Dias. Todos apresentaram similaridade de 100\% (um dos alinhamentos está disposto na Figura 12).

Esta espécie é de grande destaque epidemiológico, pois é considerada uma "ponte" entre os ciclos urbano e silvestre da febre amarela (JOHNSON, 
et al, 2010) e, pode potencialmente carrear o vírus Chikungunya, recentemente introduzido no Brasil (VEGA-RÚA et al, 2014).

Conforme os dois dendogramas gerados pelas sequências de todos os parques (Figuras 26 e 27), os 3 exemplares aparecem juntos no mesmo cluster como esperado, devido à alta similaridade entre elas.

A espécie $C x$. declarator foi registrada em 10 dos 35 parques do estudo de biodiversidade e sequenciado nos parques Ibirapuera e Santo Dias. Apresentou $100 \%$ de similaridade com Cx. bidens e $99 \%$ de similaridade com $C x$. declarator, nos dois parques, conforme a figura 16, referente às espécies que o GenBank® alinhou. Cx. declarator é uma espécie noturna, tem tendências à ornitofilia, mas pica o homem ocasionalmente e parece estar envolvido na transmissão de arbovirus no Brasil (LOURENÇO-DE-OLIVEIRA,1994).

A espécie $C x$. bidens foi relatada pela primeira vez na Colômbia, apesar desse país apresentar uma fauna de mosquitos bem diversificada. A identificação molecular das duas espécies não pode ser comprovada apenas através de Biologia Molecular com marcadores nucleares ou mitocondriais. As diferenças até o momento, são confirmadas por uma única característica na genitália masculina (LAURITO, 2018). Em 2011, Demari et al, obtiveram resultados semelhantes com o marcador ITS2, com uma resposta da distância intersepecífica de $0,5 \%$ entre as espécies, o que indica que o status taxonômico das mesmas deva ser investigado em estudos posteriores.

Cx. dolosus (tabela 5) foi identificado nos parques Anhanguera, Ibirapuera e Shangrilá. O único espécime sequenciado, do parque Ibirapuera, apresentou 99\% de similaridade com o espécime do GenBank®. Possui hábitos alimentares ecléticos e são considerados vetores potenciais de arboviroses, que podem causar infecções no homem e nos animais domésticos. Após a dissecção de mosquitos adultos, foram encontradas larvas (L3) da filária Dirofilaria immitis que, apesar de parasitar cães, gatos e furões, pode ocasionalmente parasitar as câmaras cardíacas do ser humano, o tecido subcutâneo e as artérias pulmonares, causando graves danos (MARCONDES, 2011). A espécie presente no parque Ibirapuera (um dos mais visitados parques de São Paulo) é uma informação relevante para as ações de vigilância. 
Para $C x .(C x$.$) sp grupo Coronator (ver tabela 5, todos os parques), o$ resultado foi $99 \%$ de similaridade com a mesma espécie, do parque Ibirapuera. A espécie foi identificada nos parques Anhanguera, Ibirapuera e Shangrilá e, apesar de terem sido coletados poucos exemplares, há a necessidade de mais estudos, já que foi encontrada veiculando arbovírus causadores de encefalites. Algumas dessas arboviroses são de grande importância epidemiológica, como o vírus da Encefalite Equina Venezuelana no México, o vírus da Encefalite Mucambo, na região amazônica e o vírus da Encefalite de Saint Louis (MARCONDES, 2011).

A espécie Ma. titillans, apesar da pouca frequência nas coletas, o único exemplar do parque Ibirapuera foi sequenciado e, apresentou $90 \%$ de similaridade com outras duas espécies: Wyeomyia ulocoma e Culicidae sp., conforme a Figura 15. O que indica a necessidade de registro da espécie no GenBank® para posteriores sequenciamentos e futuros estudos e comparações. As fêmeas desta espécie são mosquitos robustos, vorazes e muito agressivos.

Sugam o sangue de aves, mamíferos e do homem, com atividade preferencialmente exofílica. Os horários preferidos dessa espécie são os crepúsculos matutino e vespertino e, foram encontrados parasitados naturalmente com o vírus da Encefalite Equina Venezuelana, o qual causa no

ser humano dores retro-oculares, náuseas, febre, dores de cabeça intensas, calafrios. Nas crianças menores de 5 anos, em 35\% dos casos, há sequelas neurológicas (MARCONDES, 2011). Essas informações justificam estudos mais aprofundados para essa espécie.

Toxorhynchites sp. foi coletado nos parques Santo Dias e Ibirapuera. E nos estudos posteriores foi coletado nos demais parques desta pesquisa (MEDEIROS-SOUSA, 2014). Os espécimes sequenciado foram o do parque Ibirapuera, apresentando 99\% de similaridade com outro exemplar da mesma espécie coletado no Brasil o do parque Shangrilá, com 98\% de similaridade no alinhamento do GenBank®. A espécie não tem importância epidemiológica, já que os adultos não apresentam hábitos hematófagos.

As formas imaturas dessa espécie apresentam comportamento predatório, controlando a população de espécies como Ae. aegypti e 
Cx. quinquefasciatus, de grande importância epidemiológica (CONSOLI \& LOURENÇO-DE-OLIVEIRA, 1994; FORATTINI, 2002).

Outra espécie pesquisada foi um exemplar do Ae. (Och.) crinifer, do parque Anhanguera. Nos alinhamentos apresentou 97\% de similaridade com a espécie Ochlerotatus crinifer (tabela 6), um espécime da Argentina, de acordo com o GenBank®. Foram coletados poucos exemplares, sendo que dos parques do estudo, apenas no Anhanguera a espécie foi identificada. Uma hipótese que pode justificar o aparecimento de poucos espécimes desta espécie, é que talvez no momento da coleta, o local não tenha tido as características ambientais e alimentares para sustentar uma população maior no período do estudo.

Ae. fluviatilis foi capturado em 21 parques dos 35 do estudo anterior (MEDEIROS-SOUSA, 2013). Foram sequenciados um exemplar do Parque Anhanguera e um do parque Shangrilá. $O$ do parque Anhanguera apresentou $100 \%$ de similaridade no alinhamento com a mesma espécie presente no GenBank® (tabela 6). Já o do parque Shangrilá, 99\% com a mesma espécie (tabela 9).

A espécie foi classificada em quarto lugar em relação à frequência nos 35 parques. Tem preferência pelos locais escavados em rochas onde há água da chuva acumulada, nos ambientes silvestres. Mas frequenta os ambientes peridomiciliares juntamente com Ae. aegypti e Cx. quinquefasciatus. Alimenta-se em répteis, aves e mamíferos e, em condições experimentais prefere o ser humano. No laboratório, foi competente para infectar-se com o vírus da Febre Amarela e Dirofilaria immitis. Destaca-se também por ser um dos modelos experimentais mais utilizados para malária, em todos os continentes (CONSOLI \& LOURENÇO-DE-OLIVEIRA, 1994; FORATTINI, 2002)

Um exemplar de Cx. sp. do parque Anhanguera foi selecionado para 0 estudo. Foi coletado em 22 dos 35 parques da pesquisa destacando-se em segundo lugar em abundância. Foi identificado nos 4 parques e o espécime sequenciado apresentou 99\% de similaridade com Cx. eduardoi do GenBank®.

O táxon $C x$. (Cx.) sp., inclui um grupo de espécies onde as fêmeas não são morfologicamente indistinguíveis, com exceção de alguma espécies. A espécie $C x$. eduardoi prefere ambientes silvestres, mas sobrevivem bem aos ambientes alterados, enfetizando a capacidade de adaptação aos ambientes 
antrópicos. Esse fato é relevante nas implicações epidemiológicas (ZEQUI et al, 2005). Isso se confirma, no que diz respeito às adaptações reprodutivas a esses ambientes, pois nos estudos de biodiversidade foram coletados somente imaturos dessa espécie em 4 parques, incluindo o parque Anhanguera (MEDEIROS-SOUSA, 2013). Outro ponto importante é o ecletismo para a alimentação, já que a espécie é considerada potencial carreadora de arboviroses, que causam doenças nos animais domésticos e no homem (CONSOLI \& LOURENÇO-DE-OLIVEIRA, 1994).

A espécie Cq. venezuelensis presente apenas no parque Anhanguera, em relação aos quatro parques desta pesquisa (MEDEIROS-SOUSA, 2014), foi sequenciado e apresentou 95\% de similaridade com Cq. nigricans um exemplar da Colômbia, conforme a figura 17, o que sugere que não há registro no GenBank®. A espécie exerce suas atividades de alimentação à noite e no período de crepúsculo. Sugam sangue de diferentes espécies de hospedeiros. Em épocas de grande densidade populacional invadem as residências das pessoas, representando um sério problema, pois são muito agressivas e perturbadoras, além disso, veiculam o vírus da Encefalite Equina Venezuelana e o vírus Oropouche (CONSOLI \& LOURENÇO-DE-OLIVEIRA, 1994; MARCONDES, 2011).

Outra espécie que teve um exemplar sequenciado foi Hg. leucocelaenus, que nos estudos anteriores, foi coletada apenas no parque Anhanguera (MEDEIROS-SOUSA, 2014 e et al, 2015). O alinhamento com sequencias do GenBank® resultou em $98 \%$ de similaridade com a mesma espécie (tabela 6).

As fêmeas desta espécie tem hábitos diurnos e acrodendrófilos. Preferem buracos de árvores para a oviposição, e também foram encontradas larvas em taquaras e internódios de bambu. Outros imaturos foram registrados em recipientes artificiais abandonados nas matas $e$, inclusive em áreas de desmatamento.

A espécie apresenta boa capacidade de voo (até $6 \mathrm{~km}$ ), alimenta-se de sangue de animais e dos humanos com muita agressividade. Foi encontrada naturalmente infectada com o vírus da febre amarela, sendo considerada vetor primário do ciclo silvestre da doença no sudeste do Brasil. Outros tipos de 
arbovírus também foram registradas nessa espécie (MARCONDES, 2011;

CONSOLI \& LOURENÇO-DE-OLIVEIRA, 1994; FORATTINI, 2002).

Cx. chidesteri obteve $99 \%$ de similaridade com sequência do GenBank®. Dois exemplares foram sequenciados: o do parque Santo Dias e o do Parque Shangrilá e apresentaram o mesmo valor para ambos. Foi identificado em 12 parques dos 35 do estudo, com uma frequência razoável. As topologias das árvores gerais mostram o do parque Shangrilá como mais antigo, pois aparece como grupo externo ao do parque Santo Dias (figura 26). Na figura 27 apesar de aparecerem juntos no mesmo cluster, o do parque Shangrilá foi alocado no ramo mais longo.

Apresenta hábitos ecléticos e é considerada uma espécie vetora em potencial para alguns arbovírus, que podem causar infecções no homem e nos animais domésticos, assim como intenso desconforto (FORATTINI, 2002).

Cx. (Mcx.) sp. grupo Imitator foi identificado com uma frequência bem baixa e, somente no parque Santo Dias. Com 99\% de similaridade para $C x$. imitator para o único exemplar sequenciado. Juntamente com as espécies $C x$. dolosus e Cx. mollis, podem compreender três complexos de espécies (DEMARI, 2009).

Li. durhami foi identificado nos parques Anhanguera, Santo Dias e Shangrilá. Além de mais três parques do estudo de Medeiros et al 2013, com baixa abundância. As porcentagens de similaridade dos exemplares sequenciados foram de 98\% e 96\%, consecutivamente, com a mesma espécie registrada no GenBank® $B$. Na topologia das árvores, na árvore UPGMA (figura 22), a espécie foi colocada com Wy. sp. como grupo externo. Já a Neighborjoining coloca as duas espécies no mesmo cluster (figura 23). Isso confirma a classificação das duas espécies na tribo Sabethini (CONSOLI \& LOURENÇODE-OLIVEIRA, 1994).

Os mosquitos dessa espécie são muito bonitos, recobertos de escamas com reflexos metálicos com variações entre o amarelo e o dourado, com manchas avermelhadas ou violáceas. As formas imaturas são consideradas predadoras não obrigatórias, ou seja, somente na ausência do alimento, ou em ocasiões de encontro casual com a presa. Inclusive já foram encontradas larvas 
dessa espécie convivendo com larvas de Ae. aegypti e de Ae. albopictus (CONSOLI \& LOURENÇO-DE-OLIVEIRA, 1994; FORATTINI, 2002)

A espécie não é uma escolha para o controle biológico, pois as fêmeas adultas são hematófagas. Se alimentam com sangue humano no peridomicílio e de outros animais no período diurno. Outro fator relevante que caracteriza a espécie é que a baixa frequência de espécimes nesses ambientes, pode indicar mudanças ambientais que estão impedindo a sobrevivência nesses lugares (FORATTINI, 2002; PAULA et al, 2015).

A espécie $C x$. nigripalpus foi identificada em todos os parques desta pesquisa. Um espécime do parque Santo Dias foi sequenciado, apresentando 99\% de similaridade com a mesma espécie registrada no GenBank® (tabela 8). Foi a mais abundante no parque Anhanguera na pesquisa de 2015, com o maior número de espécimes adultos coletados (MEDEIROS-SOUSA, 2015).

Esse mosquito é mais frequente nos meses quentes e chuvosos, devido a maior variedade de criadouros. Apresenta maior atividade no período vespertino e à noite e prefere as aves, mas alimenta-se também do sangue de mamíferos de grande porte e do homem. Espécie exófila, mais comum nos ambientes silvestres, intermediários ou no peridomicílio e raramente invade as casas (CONSOLI \& LOURENÇO-DE-OLIVEIRA, 1994). Foi naturalmente encontrada infectada com o vírus da Encefalite de São Luís na região do Vale do Ribeira e como potencial vetora do Vírus do Nilo Ocidental (DEMARI, 2009).

Wyomyia. sp. teve um único exemplar do parque Santo Dias sequenciado e apresentou $92 \%$ de similaridade com a espécie Wy. splendida do GenBank®, e $89 \%$ com outro exemplar sequenciado de $W y$ sp., conforme a figura 13. $\mathrm{Na}$ topologia das árvores, na UPGMA aparece como anterior ao Aedes e aos Culex. Já na Neighbor-joining aparece como mais recente (figura 27). Essas informações justificam o registro da sequência deste espécime obtido neste estudo no GenBank®, para pesquisas posteriores.

O gênero Wyeomyia é muito problemático, pois ainda há confusões com várias espécies que foram descritas e redescritas e, várias fêmeas não podem ser distinguidas apenas pelas características morfológicas. Os imaturos criamse em internódios de bambus, bromélias, axilas de folhas e cascas de frutos. Foram encontrados vários vírus nas espécies desse gênero, o que justifica um 
maior estudo desse táxon, pois não tem preferência de hospedeiros e, em número excessivo, podem sugar o sangue dos humanos (CONSOLI \& LOURENÇO-DE-OLIVEIRA, 1994, FORATTINI, 2002).

Cx.(Mel) ribeirensis nos estudos de 2014 e 2015, foi identificado nos parques Anhanguera e Shangrilá. O espécime sequenciado foi 0 do parque Shangrilá. O mesmo apresentou 95\% de similaridade com Cx. crybda e 95\% com Cx.(Mel) ribeirensis do GenBank® (tabela 9) .

A espécie apresenta comportamentos noturnos e é favorecida pelas atividades antrópicas. Acredita-se que esteve envolvido na transmissão do vírus da Encefalite Equina do Leste, no sul do Estado de São Paulo, no Vale do Ribeira e, há registros antigos de identificação errônea como $C x$. crybda, o que justifica o resultado dos alinhamentos. Mesmo com essas características, sugere-se o estudo posterior mais aprofundado dessa espécie no parque Shangrilá e o registro da sequência no GenBank®, pois a baixa similaridade com $C x$. ribeirensis já registrado levanta a hipótese de um complexo de espécies (tabela 9).

O último exemplar desse estudo foi Ma. wilsoni, onde nos estudos de 2014 foi coletado apenas no parque Shangrilá. O espécime sequenciado apresentou $93 \%$ de similaridade com Ma. titillans, um espécime colombiano postado no GenBank®, conforme a Figura 14. Na árvore UPGMA (Figura 24) aparece como mais antigo que os Culex e na Neighbor-joining (Figura 25), aparece como mais recente.

Os mosquitos do gênero Mansonia são muito robustos e com escudos de aspecto felpudo. As espécies não são consideradas vetoras de doenças endêmicas no território brasileiro e, no Brasil já foram identificadas 9 espécies, dentre elas Ma. titillans já discutida anteriormente (CONSOLI \& LOURENÇODE-OLIVEIRA, 1994). A figura 15 mostra uma baixa porcentagem de similaridade com a mesma espécie registrada no banco de genes. Devido às informações obtidas nessa pesquisa, sugere-se o registro desse exemplar no GenBank®, com o intuito de auxiliar nos estudos futuros.

Vários estudos envolvendo o uso de outros marcadores para a continuidade de diversas pesquisas são indicados. O uso de microssatélites, por exemplo, para mosquitos de diversos gêneros estão sendo úteis para as dúvidas 
dos complexos de espécies, como já foi utilizado com o gênero Haemagogus (MÜLLER et al, 2010). O uso do marcador em amostras de locais diferentes, e em períodos temporais distintos, por exemplo seria de grande valia para a continuidade dos estudos da fauna de mosquitos dos parques da cidade de São Paulo.

A descrição da paisagem através do mapeamento possibilita verificar as formas do relevo e da vegetação, associados a processos naturais ou antrópicos. Auxilia na formação de hipóteses que sugerem a ligação entre os parques desse estudo e, consequentemente às espécies de mosquitos e de animais que existem ali.

Um fenômeno comum que ocorre com as cidades brasileiras é 0 crescimento desordenado. Isso é uma consequência da falta de planejamento urbano. Nesse sentido os administradores do espaço comum e a população começam a perceber a vegetação como componente necessário nas cidades. Daí a necessidade de vigilância e maiores estudos das malhas verdes da cidade, principalmente no que diz respeito ao entorno urbanizado com 0 mapeamento e às espécies que ali habitam.

A análise das áreas de cada parque quanto às áreas de cobertura vegetal de cada parque, o tamanho de cada parque em hectares e as distâncias euclidianas entre eles (Tabela 10), mostrou que o parque de maior tamanho, o Parque Anhanguera, é o parque mais distante e com menos conexão com os outros três parques estudados. Nos estudos de biodiversidade dos mosquitos nos parques municipais da cidade de São Paulo, mostrou que o Parque Anhanguera foi o parque mais rico em espécies, com 26 categorias taxonômicas, Ibirapuera com 15 e Shangrilá com 14 (MEDEIROS-SOUSA et al, 2013). Esse fenômeno pode ser explicado pela exuberância do parque Anhanguera, pela quantidade de vegetação e pela menor proximidade da malha urbana (Figura 28). Além de ser uma das maiores áreas verdes da cidade, com uma fauna (230 espécies) e flora (204 espécies) variadas e, há a presença de vegetação remanescente da Mata Atlântica (BOCARDI et al, 2013).

Quanto maior o grau de heterogeneidade estrutural de um bioma, maior a diversificação dos recursos no habitat, permitindo a coexistência de um número maior de espécies (JAMMONEAU et al, 2011). Esse aumento pode também 
minimizar o efeito da competição e, por consequência, aumentar a diversidade local de espécies.

É uma realidade que a fragmentação de habitat (isto é, a tendência dos habitats se tornarem menores e mais isolados) ocorre e vem causando a perda de diversidade (FAHRIG, 2003). É essa redução do habitat original, não só a perda no tamanho, mas também o isolamento das manchas de vegetação que mudam a fauna local.

Outro processo muito comum que pode ocorrer, após o desmatamento é a adaptação dos mosquitos aos ambientes modificados. Fragmentos de habitat isolados são muito importantes porque quebram os padrões de distribuição natural das espécies, direcionando as mesmas para a utilização dos ambientes que circundam os fragmentos (EWERS e DIDHAM, 2006). Essa hipótese reforça o resultado do levantamento da riqueza das espécies dos parques analisados.

A conectividade entre os fragmentos de paisagem é a capacidade que facilita o fluxo biológico (TAYLOR et al, 1993). Pelos cálculos e os resultados da Figura 29, o Parque Anhanguera aparece como o mais distante dos demais, indicando um grau importante de isolamento e um maior distanciamento da zona urbana.

A preferência pelo ambiente antrópico modificado já foi evidenciada por Ae. albitarsis, Ma. indubitans, Cq. venezuelensis (FORATTINI et al, 1993a), Ae. scapularis, Ae. serratus, Cx. nigripalpus, Cx. ribeirensi e Cx. bidens (FORATTINI et al, 1993b). Isso pode explicar a presença de Ae. albopictus nos parques Anhanguera, Ibirapuera e Santo Dias. Os três espécimes mostraram-se exatamente idênticos, com 100\% de similaridade nas sequências para o DNA barcoding. Essa porcentagem mostra que não houve fluxo genético para essa espécie nesses parques.

Esse mosquito assim como Ae. aegypti é exótico e, mesmo o Anhanguera estando mais distante dos demais parques e, mais próximo da Mata Atlântica, provavelmente a espécie foi introduzida nos três parques pelo homem, ficou isolada em cada um dos parques e muito bem adaptada (CONSOLI \& LOURENÇO-DE-OLIVEIRA, 1994).

A espécie $C x$. quinquefasciatus, extremamente adaptada ao ambiente sinantrópico, apareceu nos parques Anhanguera, Ibirapuera e Shangrilá. A 
maior quantidade de espécimes foi registrada no parque Ibirapuera, o que confirma as características antropofílicas desse mosquito e, observando o mapa, nota-se que é o parque com a maior urbanização no entorno.

Os parques Ibirapuera e Santo Dias são os mais próximos entre si. Foi observado claramente a presença de intenso entorno urbanizado ao redor desses dois parques (Figuras 28 e 29). Consequentemente, isso pode sugerir características muito parecidas entre os dois, inclusive a frequência das mesmas espécies de pássaros, já que o $C x$. declarator apresenta tendências à ornitofilia (CONSOLI\& LOURENÇO-DE-OLIVEIRA, 1994).

A preocupação com a preservação do verde nos espaços públicos deve ser uma constante para todos os cidadãos, poder público e profissionais da área no sentido de se entender que a cidade, quando cultivada e mantida a educação ambiental, constitui um ambiente mais saudável para a vida humana e, portanto mais propício ao crescimento das espécies vegetais. Assim sendo, todos os cidadãos desempenham papel importante na sua manutenção. Essa cumplicidade entre todas as esferas presentes no espaço urbano é a condição básica para o alcance de uma melhor qualidade ambiental urbana e um padrão mínimo de qualidade de vida humana. 


\section{6- CONCLUSÕES}

> As sequências dos espécimes Ae. albopictus dos parques Ibirapuera, Anhanguera e Santo Dias, foram idênticas demonstrando que o gene COI I é muito conservado e adequado para a identificação de espécies, inclusive para diferentes localidades;

$>\quad$ A utilização de outros marcadores como por exemplo microssatélites para a continuidade dos estudos e futuras confirmações das espécies: Cq. venezuelensis, Ma. titillans, Cx. declarator, Wy. sp., Cx. (Mel) ribeirensis e Ma. wilsoni é uma necessidade, assim como os registros das respectivas sequências no banco de genes produzidas nesta pesquisa;

O gene mitocondrial COI demonstra ser um importante marcador molecular para código de barras genético de animais, oferecendo a vantagem de ser espécie-específico;

$>\quad$ A utilização de outros marcadores como por exemplo microssatélites para a continuidade dos estudos e futuras confirmações das espécies: Cq. venezuelensis, Ma. titillans, Cx. declarator, Wy. sp., Cx. (mel) ribeirensis e Ma. wilsoni é uma necessidade, assim como os registros das respectivas sequências no banco de genes produzidas nesta pesquisa;

$>\quad \mathrm{O}$ uso de marcadores moleculares, juntamente com as características taxonômicas são fundamentais para a precisa identificação das espécies e para a retirada de dúvidas nos complexos e espécies;

$>\quad$ O Brasil é um país extremamente rico em biodiversidade e, por isso, é necessário a criação de bancos de dados genéticos para consolidar o conhecimento gerado por taxonomistas e sistematas do país. Isso justifica o registro no GeneBank® dos espécimes indicados nesse estudo;

$>\quad$ Para estudos posteriores de pesquisa de descrição de paisagem, sugerese o sequenciamento de espécimes de $C x$. quinquefasciatus dos demais parques para possíveis comparações;

$>\quad$ O parque Anhanguera por ser mais distante dos aglomerados humanos, proporciona a circulação de parasitas de infecções silvestres;

$>\quad O$ parque Ibirapuera por estar situado no centro da malha urbana predomina o aparecimento de espécies mais antropofílicas e sinantrópica 


\section{7- REFERÊNCIAS BIBLIOGRÁFICAS}

ANDERSON, G. S.; HUITSON, N. R. Myiasis in pet animals in British Columbia: the potential of forensic entomology for determining duration of possible neglect. The Canadian Veterinary Journal, v. 45, n. 12, p. 993, 2004.

ALJANABI, S. M. e MARTINEZ, I. Universal and rapid salt extraction of high quality genomic DNA for PCR based techniches. Nucleic Acid research $\vee 2, p$ 4692-4693, 1997.

ALTSCHUL et al, 1990. Basic Local alignment search tool (BLAST) disponível em: >http://www.blast.ncbi.nlm.nih.gov/blast.cgi

ARAGÃO, Mário B. A epidemiologia paisagística no Brasil. Cad. Saúde Pública, Rio de Janeiro, v. 4, n. 1, p. 106-109, Mar. 1988.

Áreas Verdes das Cidades - Guia de Parques disponível em https://www.areasverdesdascidades.com.br 2012.

BELLONI, A. M. C. et al. Guia de apresentação de teses. Universidade de São Paulo- USP $2^{\circ}$ ed atual. São Paulo. 2015. Disponível em: http://www.biblioteca.fsp.usp.br/guia/

BENECKE, M.; JOSEPHI, E.; ZWEIHOFF, R. Neglect of the elderly: forensic entomology cases and considerations. Forensic science international, v. 146, p. S195-S199, 2004.

BOCARDI, J. M. B., et al. Parâmetros Físicos e Químicos de Referência em Solos de Unidades de Conservação Florestal da Bacia do Paraná 3, Brasil (Physical and Chemical Parameters of Reference Soils in Forest Conservation 
Units of the Paraná Basin 3, Brazil). Revista Brasileira de Geografia Física, v. 11, n. 1, p. 099-113, 2013.

BOORE, J.L., Animal mitochondrial genomes, Nucleic Acids Research, Volume 27, Issue 8, Pages 1767-1780; 1 April 1999.

BRASIL, Lei $N^{0}$ 9.985, DE 18 de julho de 2000. Esta Lei institui o Sistema Nacional de Unidades de Conservação da Natureza Diário oficial da União, Brasília, DF Seção 1 - 19/7/2000, Página 1

CATERINO et al. Annu. Rev. Entomol. 2000. 45:1-54 2000.

CONSOLI, R. A. G. B. e LOURENÇO-DE-OLIVEIRA, R. Principais mosquitos de importância sanitária no Brasil. Rio de janeiro: Fiocruz, 1994.

DE BARRO, P. \& AHMED, M. Z. Genetic networking of the Bemisia tabaci cryptic species complex reveals pattern of biological invasions. PLoS One, v. 6, n. 10, p. e25579, 2011.

DEMARI, B. S. Estudos taxonômicos de espécies do gênero Culex (Diptera: Culicidae) da região neotropical, utilizando a subunidade I do gene mitocondrial citocromo oxidase. Dissertação de mestrado. Faculdade de Saúde Pública da Universidade de São Paulo, 2009.

DEMARI-SILVA, B. et al. Taxonomic and phylogenetic relationships between species of the genus Culex (Diptera: Culicidae) from Brazil inferred from the cytochrome c oxidase I mitochondrial gene. Journal of medical entomology, $v$. 48, n. 2, p. 272-279, 2011.

DICIONÁRIO inFormal: Dicionário Online 2009. Disponível em: https://www.dicionarioinformal.com.br/

DICIONÁRIO ILUSTRADO TUPI GUARANI disponível em: 
https://www.dicionariotupiguarani.com.br 2016.

DOLLFUS, O. O Espaço Geográfico. São Paulo: Difel, 4aed., 121p. 1982.

EWERS, R. M.; DIDHAM, R. K. Confounding factors in the detection of species responses to habitat fragmentation. Biological reviews, v. 81, n. 1, p. 117-142, 2006.

FARAH, S. B. DNA segredos \& mistérios. São Paulo, Sarvier, 2000.

FAHRIG, L. 2003. Effects of habitat fragmentation on biodiversity. Annual review of ecology, evolution, and systematics 34: 487-515. 2003.

FARIELLO, F. La arquitectura de los jardines: De la antigüedad al siglo XX. Editorial Reverte. Itália- Roma, 2004.

FERREIRA, M. E. \& GRATTAPAGLIA, D. Introdução ao uso de marcadores moleculares em análise genética. 3 ed. Brasília: Embrapa-Cenargen, 1998.

FUNDAÇÃO OSWALDO CRUZ (Fiocruz): Ciência e tecnologia em saúde Disponível em: https://portal.fiocruz.br/

FOLMER, O. M.; BLACK, W.; HOEH, R.; LUTZ, R. V. DNA primers for amplification of mitochondrial cytochrome $c$ oxidase subunit I from diverse metazoan invertebrates. Molecular Marine Biology and Biotechnology. 3, pp. 294-297 1994.

FORATTINI, O. P., GOMES, A. D. C., SANTOS, J. L. F., GALATI, E. A. B., RABELLO, E. X., \& NATAL, D. Observações sobre atividade de mosquitos Culicidae, em mata residual no Vale do Ribeira, S. Paulo, Brasil. Revista de Saúde Pública, 15, 557-586, 1981. 
FORATTINI, O. P.; GOMES, A. C.; KAKITANI, I. and MARUCCI, D. Observações sobre domiciliação de mosquitos Culex (Melanoconion), em ambiente com acentuadas modificações antrópicas. Rev. Saúde Pública, São Paulo, v. 25, n. 4, p. 257-266, Aug. 1991.

FORATTINI, OP, I. KAKITANI, E. MASSAD e D. MARUCCI. 1993a . Estudos sobre mosquitos (Diptera: Culicidae) e ambiente antrópico. 3. Pesquisa de formas adultas no sistema de irrigação de arroz e emergência de Anopheles albitarsis no Sudeste, Brasil. Rev. Saúde Públ. $27: 313$.

FORATTINI, OP, I. KAKITANI, E. MASSAD e D. MARUCCI. 1993b . Estudos sobre mosquitos (Diptera: Culicidae) e ambiente antrópico . 4. Levantamento de adultos em repouso e comportamento sinantrópico no sudeste do Brasil. Rev. Saúde Públ . 27 : 398.

FORATTINI. O. P. Culicidologia Médica. vol.1. Princípios gerais, morfologia, glossário taxonômico. São Paulo: Editora da USP. 548p 1996.

FORATTINI, O. P. Culicidologia Médica. vol. 2. Identificação, Biologia, Epidemiologia. Editora da Universidade de São Paulo - Edusp, São Paulo SP, 860p. 2002.

GOOGLE. Mountain View, Califórnia, EUA. Disponível em: www.google.com

GOOGLE EARTH. EUA. Disponível em: https://www.google.com/earth/

Guia dos Parques Municipais de São Paulo - Prefeitura. Disponível em: www.prefeitura.sp.gov.br/cidade/secretarias/upload/.../guia-parquesmunicipais.pdf 2014

GUIDON S., GASCUEL O. A simple fast and accurate algorithm to estimate large phylogenies by maximum likelihood. Systematics Biologists. 52: 639-704, 2003. 
GenBank Overview - NCBI - NIH- disponível em: https://www.ncbi.nlm.nih.gov/genbank/

GUIMARAES, A. E.; ARLE, M.; MACHADO, R. N. M.. Mosquitos no Parque Nacional da Serra dos Orgãos, estado do Rio de Janeiro, Brasil: IV. Preferência alimentar. Mem. Inst. Oswaldo Cruz, Rio de Janeiro, v. 82, n. 2, p. 277-285, jun. 1987 .

HARBACH, R. E. \& KITHING, I. J. Phylogeny and classification of the Culicidae (Diptera). Systematic Entomology. 23:327-370, 1998.

HARBACH, R. E. The Culicidae (Diptera): review and taxonomy, classification and phylogeny. Zootaxa. 1668:591-638, 2007.

HARBACH, R. E. Mosquito taxonomic inventory. 2013.

HAYMER, D. S.; MCINNIS, D. O. Resolution of populations of the Mediterranean fruit fly at the DNA level using random primers for the polymerase chain reaction. Genome, v. 37, n. 2, p. 244-248, 1994.

HEBERT, P. et al, 2003. DNA barcoding. Disponível em: http://www.barcodinglife.org

HONÓRIO, A. N.; CÂMARA, P.C.D.; CALVET, A. G., Brasil, P. Chikungunya: an arbovirus infection in the process of establishment and expansion in Brazil Cad. Saúde Pública, Rio de Janeiro, 31(5):1-3, mai, 2015.

IBGE. Instituto Brasileiro de Geografia e Estatística. Disponível em: http://www.ibge.gov.br 
JOHNSON, P. T. J.; THIELTGES, D. W. Diversity, decoys and the dilution effect: how ecological communities affect disease risk. The Journal of Experimental Biology, v. 213, 961-970, 2010.

JAMONEAU, A.; CHABRERIE, O.; CLOSSET-KOPP, D. \& DEMOCOCQ, G. Fragmentation alters beta-diversity patterns of habitat specialists within metacommunities. Ecography, 34: 1-10, 2011.

KRZYWINSKI, J. \& BESANSKY, N. J. Molecular systematic of Anopheles: from subgenera to subpopulations. Annu Rev Entomol. 48:111-139, 2003.

KUMAR, N. P.; RAJAVEL, A. R.; NATARAJAN, R.; JAMBULINGAM, P. DNA barcodes can distinguish espécies of indian mosquitoes (Diptera: Culicidae). J. Med Entomol, 44(1):1-7, 2007.

LANDSAT disponível em: http://landsat.usgs.gov/mission_headlines2012.php

LANE, J. Neotropical Culicidae. 2. v. Universidade de São Paulo, São Paulo, 1953.

LAPORTA, G. Z.; URBINATTI, P. R., \& NATAL, D. Aspectos ecológicos da população de Culex quinquefasciatus Say (Diptera, Culicidae) em abrigos situados no Parque Ecológico do Tietê, São Paulo, SP. Rev Bras Entomol,50(1), 125-7, 2006.

LAURITO M, HOYOS-LÓPEZ R. First record of Culex (Culex) bidens (Diptera: Culicidae) in Colombia: Taxonomic and epidemiological implications. Acta Trop. Dec;188:251-257, 2018.

LESSINGER, AC E AZEREDO-ESPIN, AM. Evolution and structural organisation of mitochondrial DNA control region of myiasis-causing flies. Med Vet Entomol. 2000 Mar;14(1):71-80. 
LIÓ, P. \& GOLDMAN, N. Models of molecular evolution and phylogeny. Genome Res. 1233-1244,1998.

LORENÇO-DE-OLIVEIRA, R., SILVA, T.F., HEYDEN, R., Alguns aspectos da ecologia dos mosquitos (Diptera: Culicidae) de uma área de planície (Granjas Calábria), em Jacarepaguá, Rio de Janeiro: III. Preferência horária das fêmeas para o hematofagismo. Mem. Inst. Oswaldo Cruz, Rio de Janeiro, v. 80, n. 2, p. 195-201, June 1985.

LUNT, D. H.; ZHANG, D. X.; SZYMURA, J. M.; HEWITT, G. M. The insect cytocrome oxidase I gene: evolucionary patterns and conserved primers for phylogenetic studies. Insect Mol Biol. 5(3):153-165, 1996.

MACHADO, C. J. S. \& RAMOS, R. R. Ecologia e Doenças Infecciosas: Um Perfil Nacional dos Grupos de Pesquisa do CNPQ. Acta Scientiae et Technicae, v. 1, n. 2, 2013.

MAGNOLI, M. M. O parque no desenho urbano. Paisagem e Ambiente, (21), 199-213, 2006.

MARCONDES, C. B. Entomologia médica e veterinária. In: Entomologia médica e veterinária. 2011.

MEDEIROS-SOUZA, A. R. et al. Biodiversidade de mosquitos (Diptera: Culicidae) nos parques da cidade de São Paulo I. Biota Neotropica, 13 (1): 317 321, 2013.

MEDEIROS-SOUSA A R, CERETTI, W., URBINATTI, P R., de CARVALHO G.C., de PAULA MB, FERNANDES, A., et al. Mosquito fauna in municipal parks of São Paulo City, Brazil: a preliminary survey. J Am Mosq Control Assoc;29: 275-9, . 2013. 
MEDEIROS-SOUSA, A.R., Estudo dos padrões de diversidade de mosquitos (Díptera:Culicidae) em parques urbanos da cidade de São Paulo. Dissertação de mestrado. Faculdade de Saúde Pública da Universidade de São Paulo, 2014.

MEDEIROS-SOUSA, A. R., CERETTI, W., de CARVALHO G.C., M.S. NARDI, ARAÚJO, A. B., VENDRAMI, D.P., MARRELLI, M.T. Diversity and abundance of mosquitoes (Diptera:Culicidae)in na urban park: larval habitats and temporal variation. Acta Tropica 150 200/209, 2015.

MCCALLUM, H. Landscape Structure, Disturbance, and Disease Dynamics. In: OS TFELD, R. S.; KESSING, F.; EVINER, V. T. Infectious Disease Ecology: Effects of Ecosystems on Disease and of Disease on Ecosystems. Princeton University Press, cap 5, 2008.

MENNEH, M., \& COELHO, A. M. Características do sistema de parques públicos urbanos da cidade de São Paulo. ENCONTRO NACIONAL DE CONFORTO NO AMBIENTE CONSTRUíDO, 8., 2000.

MILLER, E.; RUPPERT, A.; The effects of host diversity on vector-borne disease: The conditions under which diversity will amplify or dilute the disease risk. PlosOne, v. 8, 2013.

MONTAGNER, F. R. G.; SILVA, O. S. e JAHNKE, S. M. Ocorrência de espécies de mosquitos associada à composição de paisagem em áreas verdes urbanas. Braz. J. Biol.[online], vol.78, n.2 , 2018.

MONTES, J. Culicidae fauna of Serra da Cantareira, Sao Paulo, Brazil. Revista de Saúde Pública, 39(4), 578-584, 2005.

MORAES, S. A. ; MARRELLI, M. T.; NATAL, D. Aspectos da distribuição de Culex (Culex) quinquefasciatus Say (Diptera, Culicidae) na região do rio 
Pinheiros, na cidade de São Paulo, Estado de São Paulo, Brasil Revista Brasileira de Entomologia 50(3): 413-418, setembro 2006.

MOUNT, D. W. Using the basic local alignment search tool (BLAST). Cold Spring Harbor Protocols, (7), pdb-top17, 2007.

MÜLLER, G.A.; MARCONDES, C.B.; NAVARRO-SILVA, M.A. Aplicações de marcadores microssatélites para o estudo de Culicidae (Diptera): revisão com especial referência a Haemagogus. Boletín de Malariología y Salude Ambiental, v.02, p.175-186, 2010.

NATAL, D. et al. O mosquito das águas poluídas. Saneas, 2004.

NATAL, D. \& MARUCCI, D. Aparelho de sucção tipo aspirador para captura de mosquitos. Revista de Saúde Pública 18:418-420, 1984.

O'BRIEN, C. \& TURNER, B. Impact of paracetamol on Calliphora vicina larval development. International journal of legal medicine, v. 118, n. 4, p. 188-189, 2004.

OGRZEWALSKA, M.; UEZU, A.; JENKINS, C. N.; LABRUNA, M. B. Effect of Forest Fragmentation on Tick Infestations of Birds and Tick Infection Rates by Rickettsia in the Atlantic Forest of Brazil. EcoHealth, v.8, 320-331, 2011.

OLIVA, A. Insects of forensic significance in Argentina. Forensic science international, v. 120, n. 1, p. 145-154, 2001.

OLIVEIRA-COSTA, J. Entomologia forense: quando os insetos são os vestígios. In: Tratado de perícias criminalísticas. Campinas, SP. Millennium, 2008.

OSTFELD, R. S.; KEESING, F. Effects of Host Diversity on Infectious Disease. Annu. Rev. Ecol. Evol. Syst, v. 43, 157-182, 2012. 
PATSOULA, E., et al. Molecular characterization of the Anopheles maculipennis complex during surveillance for the 2004 Olympic Games in Athens. Medical and veterinary entomology 21.1: 36-43, 2007.

PAULA, M. B. et al. Mosquitoe (díptera:Culicidae) fauna in parks in greater São Paulo, Brazil. Biota Neotropica 15(3): e20140026, 2015.

PONCIANO, L. São Paulo: 450 bairros, 450 anos. Senac, 2012.

$\begin{array}{lllll}\text { Prefeitura de } & \text { São } & \text { Paulo: }\end{array}$ http:/www.prefeitura.sp.gov.br/cidade/secretarias/meio_ambiente/parques/

REED, R. A.; JOHNSON-BARNARS, J,. BAKER, W. L. Fragmentation of a forested Rocky Mountain landscape, 1950-1993. Biological Conservation, v.75, 267-277, 1996.

REINERT, J. E. Revised list of abbreviations for genera and subgenera of Culicidae (Diptera) and notes on generic and subgeneric changes. J Am Mosq Control Assoc. 17(1):51-5, 2001.

REY, L. Parasitologia: parasitos e doenças parasitárias do homem nos trópicos ocidentais. 4. ed. Rio de Janeiro: Guanabara Koogan, 2008.

SANDOVAL, R. C. S. Marcadores Moleculares como ferramentas para a identificação de dípteros de importância forense (Calliphoridae, Muscidae). 2011. UFPR, Dissertação apresentada à Coordenação do Programa de PósGraduação em Ciências Biológicas, Área de Concentração em Entomologia, Universidade Federal do Paraná, Curitiba, PR, 2011.

SAENG, A. et al. Molecular and cytogenetic evidence of three sibling species of the Anopheles barbirostris Form A (Diptera: Culicidae) in Thailand. Parasitology research $102.3:$ 499-507, 2008. 
SCARPASSA, V. M. and CONN, J. E. Molecular differentiation in natural populations of Anopheles oswaldoi sensu lato (Diptera: Culicidae) from the Brazilian Amazon, using sequences of the $\mathrm{COI}$ gene from mitochondrial DNA. Genet Mol Res 5.3: 493-502, 2006.

SCARPASSA, V. M.; CARDOZA, T. B.; and CARDOSO, R. P. Population genetics and phylogeography of Aedes aegypti (Diptera: Culicidae) from Brazil. The American journal of tropical medicine and hygiene 78.6 : 895903, 2008.

SALLUM, M. A. M. et al. Phylogeny of Anophelinae (Diptera: Culicidae) based on nuclear ribosomal and mitochondrial DNA sequences. Systematic Entomology 27.3 361-382, 2002.

SAMBROOK, J.; FRITSCH, E. F.; MANIATIS, T. Molecular cloning. A laboratory manual 2 ed. Cold spring harbor laboratory press, 1989.

SÃO PAULO BAIRROS - Guia de Bairros, Cultura, Turismo e Utilidades . Disponível em: www.spbairros.com.br/ 2018.

SECRETARIA MUNICIPAL DO VERDE E MEIO AMBIENTE - Prefeitura de São Paulo Disponível em: https://www.prefeitura.sp.gov.br/cidade/secretarias/meio_ambiente/

SILVA, E. R.; SCHRAMM, F. R. A questão ecológica: entre a ciência e a ideologia/utopia de uma época. Cadernos de Saúde Pública, v. 13, n. 3, p. 355365, 1997.

SILVA, B. D. Estudos taxonômicos de espécies do gênero Culex (Diptera: Culicidae) da região neotropical, utilizando a subunidade I do gene mitocondrial citocromo oxidase. 2009. Universidade de São Paulo. USP Dissertação apresentada ao Programa de Pós-graduação em Saúde Pública . Faculdade de Saúde Pública da Universidade de São Paulo. São Paulo, 2009. 
SILVA, D. B. et al. Taxonomic and phylogenetic relationships between species of the genus Culex (Diptera: Culicidae) from Brasil inferred from the cytochrome $\mathrm{C}$ oxidase I mitochondrial gene. Journal of Medical Entomology. 48 (2): 272-279, 2011.

Sistema de informações florestais do

Estado de São Paulo, disponível em: http://www.iflorestal.sp.gov.br/sifesp/

SILVÉRIO, E. C. \& URBINATTI, P. R. Presença de mosquitos (Diptera: Culicidae) em piscinões na zona leste de São Paulo. Revista da Sociedade Brasileira de Medicina Tropical 44(4):504-507, jul-ago, 2011.

SWOFFORD, D. L. PAUP*: Phylogenetic analysis using parsimony ( ${ }^{*}$ and other methods). Version 4. Sinauer Associates, Sunderland, Massachusets, 1998.

TAMURA, K. \& NEI, M. Estimation of the Number of Nucleotide Substitutions in the Control Region of Mitochondrial DNA in Humans and Chimpanzees. Molecular Biology and Evolution. 10 (3) 512-526, 1993.

TAIPE-LAGOS, C. B. \& NATAL, D. Abundância de culicídeos em área metropolitana preservada e suas implicações epidemiológicas. Revista de Saúde Pública, (37) 3:275-9, 2003.

TAYLOR, P. D. et al. Connectivity is a vital element of landscape structure. Oikos, p. 571-573, 1993.

THE GUARDIAN JOURNAL Kings Place, London. Disponível em: https://www.theguardian.com/us 2015. 
TURCHETTO-ZOLET, A. C. et al. Phylogeographical patterns shed light on evolutionary process in S outh A merica. Molecular ecology, v. 22, n. 5, p. 1193-1213, 2013.

TORRES, B. B, \& MARZZOCO, A. Bioquímica básica. Segunda edição. Guanabara Koogan, Rio de Janeiro, RJ. 1999.

TRIP ADVISOR. Needham, Massachusetts, EUA Disponível em: https://www.tripadvisor.com.br/

UEZU, A.; METZGER, J. and VIELLIARD, J. Effects of structural and functional connectivity and patch size on the abundance of seven Atlantic Forest bird species. Biol. Cons. 123: 507-519, 2005.

URBINATTI, P. R.; SENDACZ, S. \& NATAL, D. Immature mosquitoes (Diptera: Culicidae) in a public city park. Revista de Saúde Pública, 35(5), 461-466. 2001.

UNIVERSIDADE FEDERAL DO ACRE- Disponível em: www.ufac.br

VEGA-RÚA A., ZOUACHE K., GIROD R., FAILLOUX A.-B., LOURENÇO-DEOLIVEIRA R. High level of vector competence of Aedes aegypti and Aedes albopictus from ten American countries as a crucial factor in the spread of Chikungunya virus J. Virol . 2014; 88 (11): 6294-6306.

YANG Z. \& KUMAR S. Aproximate methods for estimating the pattern of nucleotide substitution and the variation of substitution rates among sites. Mol Biol Evol. 13:650-659, 1996.

WILSON, A. C.; CANN R. L.; CARR, S. M.; STEVEN, M. C.; GEORGE, M.; GYLLESTEN, U. B. et al. Mitochondrial DNA and two perspectives on evolutionary genetics. Biol. J. Linn Soc., 26:375-400, 1985. 
ZEQUI J.A., LOPES J., MEDRI I.M. (2005) Imaturos de Culicidae (Diptera) encontrados em recipientes em mata residual no municipio de Londrina, Paraná, Brasil. Rev Bras Zool 22: 656-6

\section{8- CURRÍCULOS LATTES}

Laura de Freitas Souza Sayão Endereço para acessar este CV:

http://lattes.cnpq.br/5613774395638959

Última atualização do currículo em 09/10/2018

Doutoranda do Programa de Saúde Pública da Universidade de São Paulo-USP, conceito CAPES 6. Mestre em Ciências pela Universidade de São Paulo-USP-Instituto de Ciências Biomédicas na área de Parasitologia-2003, conceito CAPES 7. Possui graduação em Enfermagem pela Universidade Federal do Rio Grande- FURG (1997). Especialista em Formação de docentes para ensino profissional em Enfermagem. Tem experiência no ensino técnico com jovens e adolescentes com Química e Biologia básicas e Enfermagem. Docente de cursos de graduação e pós-graduação nas áreas de Parasitologia, Biossegurança, Enfermagem Cirúrgica e Saúde mental. (Texto informado pelo autor)

Nome Laura de Freitas Souza Sayão Nome em citações bibliográficas SOUZA, LF.;SOUZA, LAURAFREITAS;SAYÃO, LAURAFREITASSOUZA;SAYÃO, LAURADEF. SOUZA;SAYÃO, LAURADEF.S.

Endereço Profissional UNIVERSIDADE DE SÃO PAULO-FSP, FACULDADE DE SAÚDE PÚBLICA.

AVENIDA DOUTOR ARNALDO, 715

Pacaembu

01246904 - São Paulo, SP - Brasil

Telefone: (11)30617710

URL da Homepage: www.fsp.usp.br

Formação acadêmica/titulação

2015 \} Doutorado em andamento em Saúde Pública (Conceito CAPES 6).

Universidade de São Paulo, USP, Brasil.

Título:DNA barcoding de mosquitos neotropicais (Diptera:Culicidae) na cidade de São Paulo e descrição de paisagem,

Orientador: ()MAURO TOLEDO MARRELLI.

Coorientador: ADRIANO PINTER DOS SANTOS.

Bolsista do(a): Coordenação de Aperfeiçoamento de Pessoal de Nível Superior, CAPES, Brasil. .

Grande área: Ciências da Saúde 
2001 - 2003 Mestrado em Ciências (Biologia da Relação Patógeno-Hospedeiro)pgbmp@icb.usp.br (CAPES 7). Universidade de São Paulo, USP, Brasil.

Título: ANÁLISE DO SEGUNDO ESPAÇADOR INTERNO TRANSCRITO (ITS2) DE CARRAPATOS DO GÊNERO AMBLYOMMA, KOCK 1814 (Acari:Ixodidae) DE OCORRÊNCIA NO BRASIL,Ano de Obtenção: 2003. Orientador: (6)Dra. Teresinha Tizu Sato Schumaker.

Bolsista do(a): Coordenação de Aperfeiçoamento de Pessoal de Nível Superior, CAPES, Brasil.

Grande área: CiênciasBiológicas

2008-2010 Especialização em Formação de docentes para o ensino profissional e. (Carga Horária: 550h). Faculdade de Educação São Luís, FESL, Brasil.

Título: O relacionamento professor-aluno na prática educativa.

1994-1997 Graduação em Enfermagem.

Universidade Federal do Rio Grande, FURG, Brasil.

Título: Manual de vacinação.

Orientador: Dra. Adriana Dora da Fonsec

Mauro Toledo Marrelli Bolsista de Produtividade em Pesquisa do CNPq-Nível2

Endereço para acessar este CV: http://lattes.cnpq.br/6872138193111416

Última atualização do currículo em 26/10/2018

Professor Associado do Depto. de Epidemiologia da FSP-USP (desde 2011). Possui Bacharelado e Licenciatura em Ciências Biológicas pela Universidade Mackenzie (1990). Aperfeiçoamento em Protozoologia pelo Instituto de Medicina Tropical (FM-USP, 1992). Mestrado em Parasitologia, pelo ICB, Universidade de São Paulo (1995) e doutorado em Ciências (Biologia da Relação Patógeno-Hospedeiro) (ICB-USP, 2000). Pós-doutorado pela Case Western Reserve University (Cleveland-OH) (2002), e pela Johns Hopkins School of Public Health (Johns Hopkins University) (Baltimore-MD) (2005). Tem experiência na área de Parasitologia e Epidemiologia de doenças transmitidas por vetores, atuando principalmente nos seguintes temas: ecologia e biologia molecular de vetores, marcadores moleculares em entomologia, controles alternativos de vetores. (Texto informado pelo autor)

Identificação

Nome Mauro Toledo Marrelli

Nome em citações bibliográficas MARRELLI, M. T.;MARRELLI, MAURO TOLEDO;MARRELLI, MAURO;Marreli, MT;Marreli, Mauro Toledo;Marreli, Mauro T.

Endereço Profissional Universidade de São Paulo, Faculdade de Saúde Pública.

Av. Dr. Arnaldo 715

Cerqueira César

01246904 - Sao Paulo, SP - Brasil

Telefone: (11)30617922

Formação acadêmica/titulação

1996-2000 Doutorado em Ciências (Biologia da Relação Patógeno-

Hospedeiro)pgbmp@icb.usp.br (Conceito CAPES 7).

Universidade de São Paulo, USP, Brasil.

Título: Anophelesoswaldoi(Diptera, Culicidae):Análise do segundo espaçador interno transcrito (ITS2) do

DNA ribossômico e da susceptibilidade à infecçãocom Plasmodium vivax, Ano de obtenção:2000.

Orientador: Osvaldo Marinotti.

Bolsista do(a): Fundação de Amparo à Pesquisa do Estado de São Paulo, FAPESP, Brasil.

1993-1995 Mestrado em Ciências (Biologia da Relação Patógeno-

Hospedeiro)pgbmp@icb.usp.br (Conceito CAPES 7). 
Universidade de São Paulo, USP, Brasil.

Título: Anticorpos anti-Pfs2400 de gametócitos de Plasmodium falciparumem populações da Região

Amazônica, Ano de Obtenção: 1996.

Orientador: JK.Kloetzel.

Bolsista do(a): Coordenação de Aperfeiçoamento de Pessoal de Nível Superior, CAPES, Brasil.

1992-1993 Aperfeiçoamento em Instituto de Medicina Tropical.

Universidade de São Paulo, USP, Brasil. Ano de finalização: 1993.

Orientador: JK.Kloetzel.

Bolsista do(a): Conselho Nacional de Desenvolvimento Científico e Tecnológico, CNPq, Brasil.

1986-1989 Graduação em Bacharelado Em Ciencias Biologicas.

Universidade Presbiteriana Mackenzie, MACKENZIE, Brasil.

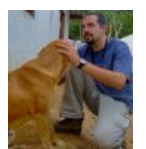

Adriano Pinter dos Santos http://lattes.cnpq.br/8887336916442663

Última atualização do currículo em 13/09/2018

Possui graduação em Medicina Veterinária e Zootecnia pela Universidade de São Paulo (2000), mestrado em Epidemiologia Experimental Aplicada Às Zoonoses pela Universidade de São Paulo (2003) e doutorado em Epidemiologia Experimental Aplicada Às Zoonoses pela Universidade de São Paulo (2007). Atualmente é pesquisador científico $V$ da Superintendência de Controle de Endemias. Tem experiência na área de Parasitologia, com ênfase em ixodideologia e epidemiologia da febre maculosa brasileira, atuando principalmente nos seguintes temas: amblyomma cajennense, amblyomma aureolatum, rickettsia rickettsii, biologia molecular e ecologia de doenças transmitidas por carrapatos (Texto informado pelo autor)

Nome Adriano Pinter dos Santos

Nome em citações bibliográficas PINTER, ADRIANO;PINTER, A.;PINTÉR, ADRIANO

Endereço ProfissionalSuperintendência de Controle de Endemias, Superintendência, Departamento de Laboratórios Especializados.

Av Paula Souza, 166

Centro 01027-000-Sao Paulo, SP-Brasil

Telefone:(11)33111177 Fax: (11)33111194

URL da Homepage: http://www.sucen.sp.gov.br

Formação acadêmica/titulação

2003 - 2007 Doutorado em Epidemiologia Experimental Aplicada Às Zoonoses (Conceito CAPES 6).

Universidade de São Paulo, USP, Brasil.

Título:Aspectos Ecológicos da Febre Maculosa em umaárea endêmica do Estado de São Paulo., Ano de obtenção: 2007.

Orientador: (9)Marcelo Bahia Labruna.

Bolsista do(a): Fundação de Amparo à Pesquisa do Estado de São Paulo, FAPESP, Brasil.

Palavras-chave: Amblyomma aureolatum; cão; Febre Maculosa; Rickettsia rickettsii; Mogi das Cruzes;

Pyriglena.

Grande área: Ciências Biológicas; Ciências da Saúde Subárea: Epidemiologia; Saúde Pública

2001-2003 Mestrado em Epidemiologia Experimental Aplicada Às Zoonoses (Conceito CAPES 6). Universidade de São Paulo, USP, Brasil.

Título: Aspectos epidemiologicos da febre maculosa em um área endêmica do município de Mogi das Cruzes (SP) e estudoem laboratório do ciclo de vida do vetor Amblyomma aureolatum

(Acari:Ixodidae),Ano de Obtenção:2003.

Orientador: Marcelo Bahia Labruna.

Bolsista do(a): Fundação de Amparo à Pesquisa do Estado de São Paulo, FAPESP, Brasil. 
Palavras-chave: Amblyomma aureolatum; Febre Maculosa; Rickettsia rickettsii; Mogi das Cruzes; cão; Rickettsia bellii. Grande área: Ciências da Saúde; Saúde Coletiva; Parasitologia

1995-2000 Graduação em Medicina Veterinária e Zootecnia.

Universidade de São Paulo, USP, Brasil.

Título: Relatório final de estágio curricular obrigatório e monografia sobre o gênero Amblyomma (Acari:Ixodidae).

Orientador: Marcelo de Campos Pereira.

Pós-doutorado 2007 - 2008 The University of Texas Medical Branch, UTMB, Estados Unidos.

Bolsista do(a): National Institutes of Health, NIH, Estados Unidos. 